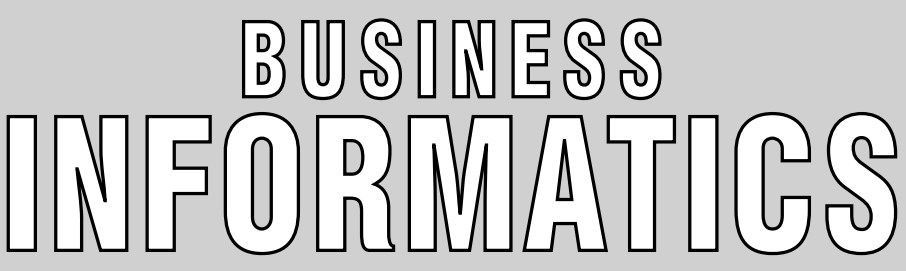

HSE SCIENTIFIC JOURNAL

\section{CONTENTS}

\section{Internet technologies}

\section{A.A. Shcherbovich}

Multistakeholder approach and human rights

in Internet Governance

\section{Modeling of social and economic systems}

\section{L.A. Ismagilova, M.V. Frants,}

M.B. Kulmukhametov

A dynamic model for assessing nonproduction

(labor) losses of an enterprise 14

N.K. Khachatryan, A.S. Akopov

Model for organizing cargo transportation with an initial station of departure and a final station of cargo distribution.

\section{L.R. Chernyakhovskaya, A.F. Galiullina}

Development of requirements for a decision support system aimed at quality assessment of public services provided based on the ontological approach 36

\section{Mathematical methods and algorithms of business informatics}

\section{M.S. Dvoretckii}

A segment tree based Top-k RMQ algorithm and its application to the autocomplete problem

\section{Yu.P. Yekhlakov, D.N. Baraksanov}

Mathematical model and algorithm for selection of Internet sites and places for display of communication messages in planning advertising campaigns

\section{I.A. Hodashinsky, S.S. Samsonov}

Design of fuzzy rule based classifier using the monkey algorithm

\section{Information security}

\section{S.A. Glushenko}

An adaptive neuro-fuzzy inference system for assessment of risks to an organization's information security 68

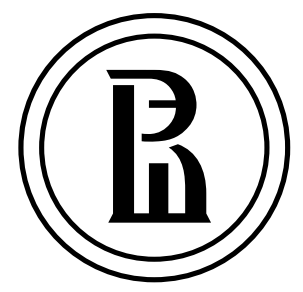

Publisher:

National Research University Higher School of Economics

Subscription index in the «Rospechat» catalogue 72315

The journal is published quarterly

The journal is included into the list of peer reviewed scientific editions established by the Supreme Certification Commission of the Ministry of Education and Science of the Russian Federation

\author{
Editor-in-Chief: \\ A. Golosov \\ Deputy Editor-in-Chief \\ Y. Koucheryavy \\ Computer Making-up: \\ O. Bogdanovich
}

Website Administration: I. Khrustaleva

Address:

33, Kirpichnaya Street, Moscow, 105187, Russian Federation

Tel./fax: +7 (495) 771-32-38 http://bijournal.hse.ru E-mail: bijournal@hse.ru

Printed in HSE Printing House 3, Kochnovsky Proezd, Moscow, Russian Federation

(C) National Research University Higher School of Economics 
$\mathrm{B}$

usiness Informatics is a peer reviewed interdisciplinary academic journal published since 2007 by National Research University Higher School of Economics (HSE), Moscow, Russian Federation. The journal is administered by School of Business Informatics. The journal is published quarterly.

The mission of the journal is to develop business informatics as a new field within both information technologies and management. It provides dissemination of latest technical and methodological developments, promotes new competences and provides a framework for discussion in the field of application of modern IT solutions in business, management and economics.

The journal publishes papers in the areas of, but not limited to:

$\downarrow$ data analysis and intelligence systems

$\checkmark$ information systems and technologies in business

$\uparrow$ mathematical methods and algorithms of business informatics

$\downarrow$ software engineering

$\downarrow$ Internet technologies

$\uparrow$ business processes modeling and analysis

$\uparrow$ standardization, certification, quality, innovations

$\uparrow$ legal aspects of business informatics

$\downarrow$ decision making and business intelligence

$\uparrow$ modeling of social and economic systems

$\uparrow$ information security.

The journal is included into the list of peer reviewed scientific editions established by the Supreme Certification Commission of the Ministry of Education and Science of the Russian Federation.

The journal is included into Russian Science Citation Index (RSCI) database on the Web of Science platform.

International Standard Serial Number (ISSN) 1998-0663.

Editor-in-Chief: Dr. Alexey Golosov - President of FORS Development Center, Moscow, Russian Federation. 


\section{EDITORIAL BOARD}

\section{EDITOR-IN-CHIEF}

Alexey Golosov -

President of FORS Development Center, Russian Federation

\section{DEPUTY EDITOR-IN-CHIEF}

\section{Yevgeni Koucheryavy -}

Professor, Department of Electronics and Communication Engineering, Tampere University of Technology, Finland

\section{EDITORIAL BOARD}

\section{Habib Abdulrab -}

Professor, Mathematical and Software Engineering Department, National Institute of Applied Sciences - Institut national des sciences appliquées de Rouen (INSA de Rouen), Rouen, France

\section{Sergey Avdoshin -}

Professor, Head of School of Software Engineering,

National Research University Higher School of Economics, Russian Federation

\section{Andranik Akopov -}

Professor, Department of Business Analytics, National Research University Higher School of Economics, Russian Federation

\section{Fuad Aleskerov -}

Professor, Head of Department of Mathematics, National Research University Higher School of Economics, Russian Federation

\section{Anton Afanasyev -}

Leading Researcher, Laboratory of Social Modeling, Central Economics and Mathematics Institute, Russian Academy of Science, Russian Federation

\section{Eduard Babkin -}

Professor, Department of Information Systems and Technologies, National Research University Higher School of Economics, Russian Federation

\section{Alex Bayer -}

Head of KAFAN FX Information Services, New York, USA

\section{Alexander Baranov -}

Deputy Head of Central Scientific and Research Computing Center, Federal Tax Service of Russia, Russian Federation

\section{Jorg Becker -}

Vice-Rector, Professor, Director of European Research Center for Information Systems (ERCIS), University of Munster, Germany

\section{Vladimir Belov -}

Professor, Department of Computational and Applied Mathematics, Ryazan State Radio Engineering University, Russian Federation

\section{Andrey Gribov -}

Director General, CyberPlat Company, Russian Federation

\section{Alexander Gromov -}

Professor, Head of Department of Modeling and Business Process Optimization, National Research University Higher School of Economics, Russian Federation

\section{Vladimir Gurvich -}

Invited Professor and Researcher, Rutgers Center for Operations Research, Rutgers, The State University of New Jersey, USA

\section{Laurence Jacobs -}

Professor, Medical School, University of Zurich, Switzerland

\section{Iosif Diskin -}

Academic Supervisor, Chairmen of Scientific and Expert Council, Russian Public Opinion Research Center (VCIOM); Member of the Council, The Russian Public Chamber; Russian Federation

\section{Kurt Sandkuhl -}

Professor, Head of Department of Business Information Systems, University of Rostock, Germany

Nikolay Ilyin -

Deputy Head, Administration of Special Communication, Federal Security Guard, Russian Federation

\section{Dmitry Isaev -}

Associate Professor, Department of Business Analytics, National Research University Higher School of Economics, Russian Federation

\section{Valery Kalyagin -}

Professor, Head of Department of Applied Mathematics and Informatics, National Research University Higher School of Economics, Russian Federation

\section{Maria Kamennova -}

Director General, BPM Logic, Russian Federation

\section{Tatiana Kravchenko -}

Professor, Head of Department of Business Analytics, National Research University Higher School of Economics, Russian Federation

\section{Sergey Kuznetsov -}

Professor, Head of School of Data Analysis and Artificial Intelligence, National Research University Higher School of Economics, Russian Federation

\section{Mikhail Lugachev -}

Professor, Head of Department of Economic Informatics, Lomonosov Moscow State University, Russian Federation

\section{Svetlana Maltseva -}

Professor, Head of Department of Innovation and Business in Information Technologies, National Research University Higher School of Economics, Russian Federation

\section{Peter Major -}

Vice-chairman, Radiocommunication Advisory Group of International Telecommunication Union (ITU),

vicece-chairman of the UN Commission on Science and Technology for Development (CSTD), Geneva, Switzerland

\section{Boris Mirkin -}

Professor, School of Data Analysis and Artificial Intelligence, National Research University Higher School of Economics, Russian Federation

Vadim Mottl -

Professor, Department of Information Security Management, Tula State University, Russian Federation

\section{Dmitry Palchunov -}

Head of Department of General Informatics, Novosibirsk State University, Russian Federation

\section{Panagote (Panos) Pardalos -}

Distinguished Professor and University of Florida Research Foundation Professor, Director of Center for Applied Optimization, Department of Industrial and Systems Engineering, University of Florida, USA

\section{Albert Silantyev -}

Professor, Department of Information Business Systems, National University of Science and Technology «MISIS», Russian Federation

\section{Victor Taratoukhin -}

Managing Director, European Research Center for Information Systems (ERCIS), University of Munster, Germany

\section{Mikhail Ulyanov -}

Professor, School of Software Engineering,

National Research University Higher School of Economics,

Russian Federation 


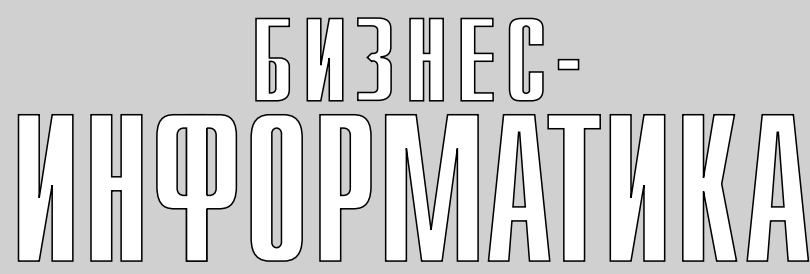

НАУЧНЫЙ ЖУРНАЛ НИУ ВШЭ

\section{СОДЕРЖАН И Е}

\section{Интернет-технологии}

А.А. Щербович

Сущность и процессуальные аспекты

мультистейкхолдер-подхода в управлении Интернетом 7

\section{Моделирование социальных и экономических систем}

Л.А. Исмагилова, М.В. Франи, М.Б. Кульмухаметов

Динамическая модель оценки непроизводственных (трудовых) потерь предприятия

Н.К. Хачатрян, А.С. Акопов

Модель организации грузоперевозок с начальной станцией отправления и конечной станцией распределения грузов

Л.Р. Черняховская, А.Ф. Галиуллина

Разработка требований к системе поддержки принятия решений для оценки качества предоставления государственных услуг с применением

онтологического подхода 36

\section{Математические методы и алгоритмы бизнес-информатики}

\section{М.С. Дворецкий}

Алгоритм нахождения $k$ наименьших элементов на отрезке (Top-k RMQ) на основе дерева отрезков и его применение в задачах автодополнения

\section{Ю.П. Ехлаков, Д.Н. Бараксанов}

Математическая модель и алгоритм выбора

Интернет-площадок и мест размещения

коммуникационных сообщений при организации

рекламных кампаний

И.А. Ходашинский, С.С. Самсонов

Построение нечеткого классификатора на основе алгоритма обезьян

\section{Информационная безопасность}

\section{С.А. Глушенко}

Адаптивная нейро-нечеткая система оценки рисков информационной безопасности организации

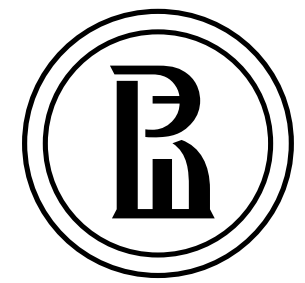

Издатель:

Национальный исследовательский университет «Высшая школа экономики»

Подписной индекс

в каталоге агентства

«Роспечать» -72315

Выпускается ежеквартально

Журнал включен в Перечень российских рецензируемых научных журналов, в которых должны быть опубликованы основные научные результаты диссертаиий на соискание ученых степеней доктора и кандидата наук

Главный редактор А.О. Голосов

Заместитель главного редактора Е.А. Кучерявый

Компьютерная верстка О.А. Богданович

Администратор веб-сайта И.И. Хрусталёва

Адрес редакции: 105187, г. Москва, ул. Кирпичная, д. 33

Тел./факс: +7 (495) 771-32-38 http://bijournal.hse.ru

E-mail: bijournal@hse.ru

За точность приведенных сведений и содержание данных, не подлежащих открытой публикации, несут ответственность авторы

При перепечатке ссылка на журнал «Бизнес-информатика» обязательна

Отпечатано в типографии НИУ ВШЭ г. Москва, Кочновский проезд, 3

(c) Национальный исследовательский университет «Высшая школа экономики» 


\section{O XКРНA^E}

$\ll \mathrm{B}$

изнес-информатика» - рецензируемый междисциплинарный научный журнал, выпускаемый с 2007 года Национальным исследовательским университетом «Высшая школа экономики» (НИУ ВШЭ). Администрирование журнала осуществляется школой бизнес-информатики НИУ ВШЭ. Журнал выпускается ежеквартально.

Миссия журнала - развитие бизнес-информатики как новой области информационных технологий и менеджмента. Журнал осуществляет распространение последних разработок технологического и методологического характера, способствует развитию соответствующих компетенций, а также обеспечивает возможности для дискуссий в области применения современных информационно-технологических решений в бизнесе, менеджменте и экономике.

Журнал публикует статьи по следующей тематике:

\ анализ данных и интеллектуальные системы

४ информационные системы и технологии в бизнесе

\ математические методы и алгоритмы бизнес-информатики

программная инженерия

$\uparrow$ Интернет-технологии

моделирование и анализ бизнес-процессов

$\checkmark$ стандартизация, сертификация, качество, инновации

$\checkmark$ правовые вопросы бизнес-информатики

↔ринятие решений и бизнес-интеллект

моделирование социальных и экономических систем

$\checkmark$ информационная безопасность.

В соответствии с решением президиума Высшей аттестационной комиссии Российской Федерации журнал включен в Перечень российских рецензируемых научных журналов, в которых должны быть опубликованы основные научные результаты диссертаций на соискание ученых степеней доктора и кандидата наук, по следующим группам научных специальностей: 05.13 .00 - информатика, вычислительная техника и управление; 05.25 .00 - документальная информация; 08.00.00 - экономические науки.

Журнал входит в базу Russian Science Citation Index (RSCI) на платформе Web of Science.

Журнал зарегистрирован Федеральной службой по надзору в сфере связи, информационных технологий и массовых коммуникаций (Роскомнадзор), свидетельство ПИ № ФС77-66609 от 08 августа 2016 г.

Международный стандартный серийный номер (ISSN) 1998-0663.

Главный редактор: Голосов Алексей Олегович, кандидат технических наук, Президент компании «ФОРС - Центр разработки». 


\section{ГЛАВНЫЙ РЕДАКТОР}

Голосов Алексей Олегович -

кандидат технических наук, Президент компании «ФОРС -

Центр разработки»

\section{ЗАМЕСТИТЕЛЬ ГЛАВНОГО РЕДАКТОРА}

\section{Кучерявый Евгений Андреевич -}

$\mathrm{PhD}$, профессор департамента электроники и коммуникаций, Технологический университет Тампере, Финляндия

\section{ЧЛЕНЫ РЕДКОЛЛЕГИИ}

Абдульраб Абиб -

$\mathrm{PhD}$, профессор департамента математики и программной инженерии, Национальный институт прикладных наук, Руан, Франция

\section{Авдошин Сергей Михайлович -}

кандидат технических наук, профессор, руководитель департамента программной инженерии, Национальный исследовательский университет «Высшая школа экономики»

\section{Акопов Андраник Сумбатович -}

доктор технических наук, профессор кафедры бизнес-аналитики, Национальный исследовательский университет

«Высшая школа экономики»

\section{Алескеров Фуад Тагиевич -}

доктор технических наук, профессор, руководитель департамента математики, Национальный исследовательский университет «Высшая школа экономики»

\section{Афанасьев Антон Александрович -}

доктор экономических наук, и.о. ведущего научного сотрудника лаборатории социального моделирования, Центральный экономиКо-математический институт РАН

\section{Бабкин Эдуард Александрович -}

кандидат технических наук, $\mathrm{PhD}$, профессор кафедры информационных систем и технологий, Национальный исследовательский университет «Высшая школа экономики»

\section{Байер Алекс -}

$\mathrm{PhD}$, Директор KAFAN FX Information Services, Нью-Йорк, США

\section{Баранов Александр Павлович -}

доктор физико-математических наук, заместитель директора ФГУП «Главный научно-исследовательский вычислительный центр Федеральной налоговой службы»

\section{Беккер Йорг -}

$\mathrm{PhD}$, проректор, профессор, директор Европейского исследовательского центра в области информационных систем (ERCIS) Мюнстерского университета, Мюнстер, Германия

\section{Белов Владимир Викторович -}

доктор технических наук, профессор кафедры вычислительной и прикладной математики, Рязанский государственный радиотехнический университет

Грибов Андрей Юрьевич -

кандидат экономических наук, Генеральный директор компании «КиберПлат»

\section{Громов Александр Игоревич -}

кандидат химических наук, профессор, заведующий кафедрой моделирования и оптимизации бизнес-процессов, Национальный исследовательский университет «Высшая школа экономики»

\section{Гурвич Владимир Александрович -}

$\mathrm{PhD}$, приглашенный профессор и исследователь,

Центр исследования операций, Ратгерский университет (Университет Нью-Джерси), США

\section{Джейкобс Лорени -}

$\mathrm{PhD}$, профессор медицинского факультета, Университет Цюриха, Швейцария

\section{Дискин Иосиф Евгеньевич -}

доктор экономических наук, научный руководитель, председатель Научно-экспертного совета, Всероссийский центр изучения общественного мнения (ВЦИОМ); член Совета Общественной палаты Российской Федерации
Зандкуль Курт -

$\mathrm{PhD}$, заведующий кафедрой информационных систем для бизнеса, Университет Ростока, Германия

\section{Ильин Николай Иванович -}

доктор технических наук, член-корреспондент Академии криптографии РФ, заместитель начальника Управления специальной связи, Федеральная служба охраны Российской Федерации (ФСО России)

\section{Исаев Дмитрий Валентинович -}

кандидат экономических наук, доцент кафедры бизнес-аналитики, Национальный исследовательский университет

«Высшая школа экономики»

\section{Калягин Валерий Александрович -}

доктор физико-математических наук, профессор, заведующий кафедрой прикладной математики и информатики, Национальный исследовательский университет «Высшая школа экономики»

\section{Каменнова Мария Сергеевна -}

кандидат технических наук, Генеральный директор компании «Логика ВРМ»

\section{Кравченко Татьяна Константиновна -}

доктор экономических наук, профессор, заведующая кафедрой бизнес-аналитики, Национальный исследовательский университет «Высшая школа экономики»

\section{Кузнеиов Сергей Олегович -}

доктор физико-математических наук, профессор, руководитель департамента анализа данных и искусственного интеллекта, Национальный исследовательский университет «Высшая школа эКономики»

\section{Лугачев Михаил Иванович -}

доктор экономических наук, профессор, заведующий кафедрой экономической информатики, Московский государственный

университет им. М.В. Ломоносова

Мальцева Светлана Валентиновна -

доктор технических наук, профессор, заведующая кафедрой инноваций и бизнеса в сфере информационных технологий,

Национальный исследовательский университет

«Высшая школа экономики»

\section{Мейор Питер -}

$\mathrm{PhD}$, заместитель директора консультативной группы по радиокоммуникациям, Международный телекоммуникационный союз (ITU), заместитель руководителя Комиссии ООН по науке и технологиям, Женева, Швейцария

\section{Миркин Борис Григорьевич -}

доктор технических наук, профессор департамента анализа данных и искусственного интеллекта, Национальный исследовательский университет «Высшая школа экономики»

\section{Моттль Вадим Вячеславович -}

доктор технических наук, профессор кафедры информационной безопасности, Тульский государственный университет

Пальчунов Дмитрий Евгеньевич -

доктор физико-математических наук, заведуюший кафедрой общей информатики, Новосибирский государственный университет

\section{Пардалос Панайот (Панос) -}

$\mathrm{PhD}$, почетный профессор, директор центра прикладной оптимизации, департамент промышленной и системной инженерии, Университет Флориды, США

\section{Силантьев Альберт Юрьевич -}

доктор технических наук, профессор кафедры информационных бизнес систем, Национальный исследовательский технологический университет «МИСиС»

\section{Таратухин Виктор Владимирович -}

кандидат технических наук, $\mathrm{PhD}$, руководитель научной группы Европейского исследовательского центра в области информационных систем (ERCIS) Мюнстерского университета, Мюнстер, Германия

\section{Ульянов Михаил Васильевич -}

доктор технических наук, профессор департамента программной инженерии, Национальный исследовательский университет «Высшая школа экономики» 


\title{
Multistakeholder approach and human rights in Internet Governance
}

\author{
Andrey A. Shcherbovich \\ Lecturer, Department of the Constitutional and Administrative Law \\ National Research University Higher School of Economics \\ Address: 20, Myasnitskaya Street, Moscow, 101000, Russian Federation \\ E-mail: ashcherbovich@hse.ru
}

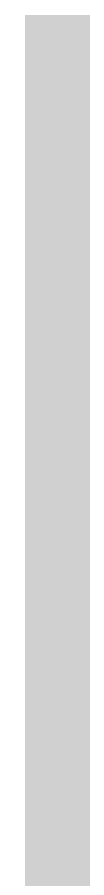

\begin{abstract}
The decision-making system in international organizations is still very conservative. The composition of international forums that can generate significant international instruments has not changed for centuries. Only diplomats and representatives of international organizations whose credentials have been confirmed in a certain way are admitted to international decision-making. The Internet Governance Forum (IGF), under the auspices of the UN, UNESCO and the International Telecommunication Union, was established in 2006 on the basis of the World Summit on the Information Society, which is today the world's most authoritative international discussion forum on Internet governance, though its potential to achieve the best regulation of international Internet governance processes is not fully used. The basis for this regulation is the multistakeholder approach, which consists in a multiplicity of categories of the decision-making mechanism, including, in addition to the traditional representatives of states and international organizations, civil society, business, the academic and technical community, the media, and other interested stakeholders.

This research is expected to provide guidance for improving the global Internet governance arrangements, taking into account the interests of all categories of participants, as well as to establish procedural rules for decision-making based on the multistakeholder approach in Internet governance to give the Internet Governance Forum the opportunity to adopt international "soft law" instruments. An example of this is the Draft Charter of Rights and Principles on the Internet, developed by the Dynamic Coalition on Human Rights and the principles of the Internet Governance Forum - something comparable to the Universal Declaration of Human Rights with regard to the Internet. The need to bring human rights instruments to the Internet determines the direction of the development of programs and policies in global Internet governance and the role of the Internet Governance Forum in these processes.
\end{abstract}

Key words: Internet Governance, Internet Governance Forum (IGF), multistakeholderism, human rights, International Labor Organization (ILO), United Nations.

Citation: Shcherbovich A.A. (2017) Multistakeholder approach and human rights in Internet Governance. Business Informatics, no. 1 (39), pp. 7-13. DOI: 10.17323/1998-0663.2017.1.7.13.

\section{Introduction}

$\mathrm{M}$ ultistakeholderism is a quite new idea of governance, but it has roots in the history of international organizations. It is a way of regulation designed to enforce proper Internet Governance on three levels: supranational, national, and selfregulation. The Internet Governance Forum (IGF), celebrating its 10th Anniversary at the 10th Meeting of the Forum on November 2015 in the Brazilian city of João
Pessoa, is a platform for expert discussions on different issues within the scope of Internet Governance.

One problem raised is modification and extension of the IGF mandate for the following five or 10-year term. However, another problem is the lack of decision-making capability of the Forum. For example, the Internet needs a system of international instruments to deal with various problems, like proper realization of human rights and the freedoms of Internet users, conflicts of jurisdic- 
tions and the questionable issue of "state sovereignty" on the national segments of the Internet or the Internet as a whole.

\section{The IGF Mandate and the issue of its extension since 2016}

The current Mandate of the IGF, extended once after a five-year term in 2010, was formulated in the Tunis agenda. The mandate of the IGF is set out in paragraphs 72 to 80 of the Tunis Agenda for the Information Society (the "Tunis Agenda"):

"We ask the UN Secretary General, in an open and inclusive process, to convene, by the second quarter of 2006, a meeting of the new forum for multistakeholder policy dialogue called the Internet Governance Forum (IGF). The mandate of the Forum is to:

$\checkmark$ discuss public policy issues related to key elements of Internet governance in order to foster the sustainability, robustness, security, stability and development of the Internet;

$\downarrow$ facilitate discourse between bodies dealing with different crosscutting international public policies regarding the Internet and discuss issues that do not fall within the scope of any existing body;

४ interface with appropriate inter-governmental organizations and other institutions on matters under their purview;

facilitate the exchange of information and best practices, and in this regard make full use of the expertise of the academic, scientific and technical communities;

$\checkmark$ advise all stakeholders in proposing ways and means to accelerate the availability and affordability of the Internet in the developing world;

$\downarrow$ strengthen and enhance the engagement of stakeholders in existing and/or future Internet governance mechanisms, particularly those from developing countries;

$\checkmark$ identify emerging issues, bring them to the attention of the relevant bodies and the general public, and, where appropriate, make recommendations;

४ contribute to capacity building for Internet governance in developing countries, drawing fully on local sources of knowledge and expertise;

promote and assess, on an on-going basis, the embodiment of WSIS principles in Internet governance processes;

$\checkmark$ discuss, inter alia, issues relating to critical Internet resources; help to find solutions to the issues arising from the use and misuse of the Internet, of particular concern to everyday users;

$\checkmark$ publish its proceedings" [1].

The United Nations General Assembly endorsed the Tunis Agenda in its resolution 60/252. The initial mandate of IGF was for five years, from 2006 to 2010. Recognizing the importance of the Forum in fostering the sustainability, robustness, security, stability and development of the Internet, as well as its role in building partnerships among different stakeholders, the United Nations General Assembly requested the Secretary General to examine the desirability of the continuation of the Forum.

Because of the five-year review, the mandate of the Forum was renewed by the General Assembly in its resolution 65/141 in 2010 for a further five years, under the patronage of the Secretary General from 2011 to 2015.

As for next term, the continuation for the IGF mandate will be reviewed by the General Assembly after the 2015 Meeting in Brazil. As stated in the UN General Assembly Resolution 69/204 "Information and communications technologies for development" adopted on 19 December 2014, the General Assembly "welcomes with appreciation the offer made by Mexico to host the meeting of the Internet Governance Forum in 2016, and recommends that the extension of the mandate of the Forum be considered in the context of the overall review in 2015" [2].

Some civil society activists of the IGF community asked for extension of the IGF. They remarked that the revolving five-year term is a barrier to long range planning and investment. Many voices have called for the strengthening of the IGF, but a longer planning horizon is necessary in such a complex, multistakeholder environment. Some initiatives to strengthen the IGF are already taking place. To address the need for sustainable funding, the Internet Governance Forum Support Association was formed at IGF 2014. The goal of this nonprofit is to promote sustainable funding for the IGF.

In order to allow the IGF to reach its full potential, the Internet Governance Forum Support Association recommends an extension of the IGF mandate, which is open-ended, without term limitation. This would ensure the stability of the IGF and support long-range planning for projects that are more comprehensive and to fund initiatives. If this were impossible under given current UN rules and regulations, the Association would recommend a stable ten-year extension, to enable longerrange commitments and financial planning. 


\section{What is the multistakeholderism?}

Multistakeholderism is a major feature of the Internet Governance Forum. The multistakeholder approach facilitates wide participation in decision-making in the international diplomacy of different groups of actors beside governments and international intergovernmental organizations which have been traditionally involved in decision-making. Since the first efforts of governing the world order using the capabilities of multilateral diplomacy, international conferences and organizations, only representatives of governments were able to participate in important international meetings.

J. Kurbalija [3] presents the "variable geometry" approach, which states that Internet governance requires the involvement of a variety of stakeholders who differ in many aspects, including international legal force, interest in particular Internet governance issues and available expertise. Such variety may be accommodated by using the variable geometry approach implied in Article 49 of the WSIS Declaration, which specifies the following roles for the main stakeholders:

$\diamond$ states - "policy authority for Internet-related public policy issues" (including international aspects);

$\diamond$ the private sector - "development of the Internet, both in the technical and economic fields";

$\diamond$ civil society - "important role on Internet matters, especially at the community level";

$\diamond$ intergovernmental organizations - "the coordination of Internet-related public policy issues";

$\diamond$ international organizations - "development of Internet-related technical standards and relevant policies" [3].

K. Gurumurthy [4] states that the "multistakeholder" format emerged through WSIS as an innovation in global negotiations, going beyond the approach of other UN summits and older forms of consensus-building and comprising practical modalities of participation, including speaking slots in working groups for non-government stakeholders not available in previous UN meetings. The WSIS Tunis agenda urged the "full involvement" 10 of the private sector, civil society and international organizations, in addition to governments, in the "international management" of the internet, asserting the need for an innovative approach to its governance embedded within the fundamental principle of multistakeholderism. This co-option by "private interests" in the WSIS itself was a reflection of the growing role of non-state actors in the UN system.

The significant influence of non-state actors in internet governance also is attributable to the particular ori- gins of new technologies in the scientific and academic communities. Freedom from state control is purported to be an indispensable cause of ICT innovations and, hence, a private role is perceived as vital for the internet's stability and growth. Within this tradition of participation, the IGF has been perceived as a pioneering experiment, paving the way to reconcile political interests through dialogue. Pivoted on the multistakeholder principle, the IGF brings together actors - predominantly seen in their identities as governments, businesses, and civil society organizations - to deliberate on specific policy themes, i.e. access, openness, diversity, security, critical internet resources and emerging issues. A multistakeholder advisory group (MAG) also guides the IGF processes [4].

J. Kulesza [5] believes that the principle of multistakeholderism means the equal involvement of all groups participating in the Internet's evolution: governments (acting on their own behalf or represented through intergovernmental organizations), civil society (representing the users) and the business sector (on behalf of not only telecommunications, but also every other market segment). This principle gives internet governance a unique character in the international relations field, one that directly determines any corresponding legal regulation. For the first time, it is not only the national authorities that need to find a working international consensus for their joint cooperation - they need to seek compromise with 'the governed' (civil society and the business sector), who usually play a subordinate role in national legal affairs. Since the Internet is a network of peers, it is only through their common consensus that the network may work perfectly [5].

There are three levels on which Internet Governance: supranational, national, and community level or self-regulation. Those three levels could not be self-sufficient, and they should be interconnected in a special way in order to make relevant Internet Governance, in order to make a model of IG policy in the realization of human rights.

Therefore, each level of Internet Governance has its positive and negative effect. None can be self-sufficient. The supranational level is like a multistakeholder approach of the IGF and other forums and open discussion spaces provided by the United Nations, by the regional Internet Governance Forums and other organizations. It is also a participatory approach, whereby everyone can participate in the discussion, and everyone has stock for decision-making. It is also an open-minded and complete scientific analysis of the problems of the Internet Governance, and the Internet Governance 


\section{Traditional model of governance}

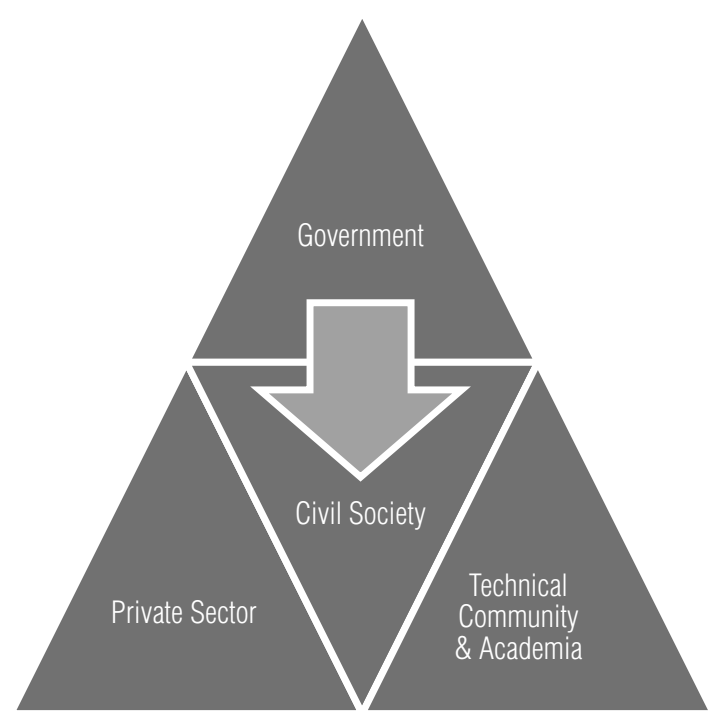

\section{Multistakeholder model of governance}

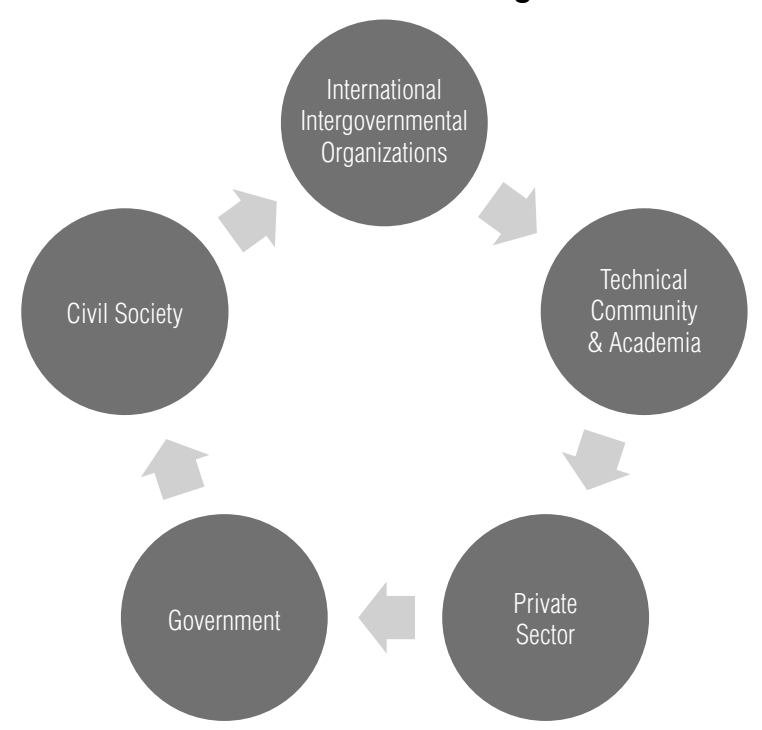

Fig. 1. Comparison of the 'traditional' and multistakeholder governance models

itself better reflects on the international level the supranational nature of the Internet itself. By the way, this supranational level on its own could have negative aspects, because it is only a discussion space which has no official decision-making power to make international treaties with mandatory force. Also, not all the national jurisdictions perceive their jurisdiction in the same way, so this recommendation could be recognized in different ways in different countries. In addition, most of the decisions and proposals made by such a discussion space are on the basis that has just an ethical or non-legal nature.

Some scholars question the potential of such governance strategies. They argue that multistakeholder approaches face a substantial number of challenges, including inadequate participation among all actors due to time constraints or conflicts of interest, difficulties in achieving consensus on key decisions, power and capability imbalances across stakeholder groups, and a lack of broader social and political legitimacy. One recent critique concludes that multistakeholder groups may be used 'as a means of promoting dialogue and building consensus, not as the locus of policy implementation and oversight'.

Counter-perspectives suggest that in several cases multistakeholder engagement has actually proved to be a more effective strategy than traditional legislative measures, resulting in enhanced standards of corporate conduct, new certification procedures, and new monitoring mechanisms, as well as in greater public awareness of corporate activities and influence. These taken together have changed the landscape and discourse concerning the roles and responsibilities of the private sector in an increasingly global economy [6].

J. Malcolm questioned at the Workshop "Human rights on the Internet: legal frameworks and technological implications", organized by the National Research University Higher School of Economics on IGF 2012 in Baku, how we regulate the Internet in a way that respects human rights if we cannot rely on governments, corporations or civil society to do so? The best answer we have is that we should do so by combining the strengths and weaknesses of all those stakeholders in a multistakeholder policy development process intended to explain common principles or guidelines upon which governments, the private sector and civil society can agree as a basis for their respective actions: passing legislation, or concluding treaties, moderating online services containing user-generated content, and share norms of online behavior [7].

The Internet Governance Forum can be a good place to start developing global policies for human rights online, particularly in areas, where there are no other global forums that have responsibility for particular issues, such as, for example, privacy and cloud services. However, the IGF, as it is currently constituted, is not quite up to the task. Its mandate calls on it to develop recommendations on emerging issues that can be transmitted to decision-makers through appropriate high-level interfaces, but it has not yet developed the capability to do that. In addition, the agenda, furthermore, calls for a parallel policy to enhance co-operation on Internet policies involving all stakeholders in their respective 
roles and led by governments. So we have some more work to do to improve the processes at the global level, and we also have to make sure that similar forums exist at the regional and national levels too. In this context, it was good to hear at this Internet Governance Forum that there will be another attempt to convene a Working Group on enhanced co-operation under the auspices of the Commission on Science \& Technology for Development. The ultimate outcome that we should be aiming for is to ensure that we have the means to address at all levels, supranational, national and local, the means to work towards a multistakeholder consensus on the appropriate principles to be applied by all stakeholders in their respective roles that will address online policy problems, while upholding human rights [7].

\section{Procedural issues and the ILO case}

Usually UN specialized agencies, like all international intergovernmental organizations, with some exceptions, have a similar structure, consisting of at least three elements: plenary bodies, executive bodies and secretariats. The same applies to all intergovernmental conferences with decision-making capacity.

The plenary body (the Assembly, the General Conference, etc.) is composed of delegates from all member states of the organization.

Executive functions are performed by the Board - a body more limited in composition.

There is also a specialized agency and the Secretariat (the Secretariat itself or the International Bureau) - the body responsible for current production in the organization, preparation of documents, as well as performing the depositary functions on concluded treaties. The highest executive officer, usually called the Secretary General, heads the Secretariat.

In a number of institutions there are subsidiary bodies designed to ensure that they function in a number of specific issues. The composition of these bodies is not typical and varies from institution to institution.

The order of the plenary, the executive and the subsidiary bodies comes under the rules of procedure - an internal document which may have different names depending on the organization, but commonly it is the rules of procedure.

The rules of procedure usually govern matters such as the procedure for regular and special sessions, adoption of the agenda, check on the credentials of delegates, the rights and responsibilities of delegates as well as officials of the body. The rules of procedure also deal with the minutes-keeping of meetings, official and working languages; the procedure of voting and elections, as well as the order of participation of members and observers, as well as procedures for making amendments and additions to the rules of procedure.

This structure comprising bodies and rules of procedure is crucial to deliver decision-making capability to the particular international organization or conference. We should mention that the IGF has almost everything to enjoy that capability. The IGF has its permanent Secretariat based in Geneva; it has an 'executive' body, the Multistakeholder Advisory Group performing executive functions for the Forum. The IGF itself could act as the plenary body. Each meeting of the IGF constitutes real plenaries on different main topics: critical internet resources, emerging issues, etc.

As we can see from the current Mandate, the IGF was created for policy dialogue but has no decision-making capacity. However, the history provides an example of a body which is multistakeholder by nature, but has official decision-making capacity. This is the International Labor Organization established in 1919.

International Labor Conference, plenary body of the International Labor Organization (ILO) is in some ways unique [8]. It includes all member states of the ILO. Each member of the ILO sends four representatives, two of whom are representatives of the Government, and the other two must be delegates representing respectively the employers and employees of each of the members of the ILO. Each government approves all delegates, but two so-called non-governmental delegates should be chosen by agreement with the trade union of employers and workers. This structure reflects the "tripartite" nature of the ILO and in fact, it is multistakeholder by nature.

The Conference of the ILO itself decides which delegates should have the right to vote, that is the "voting section". Excluded delegates have the right to appeal to a special committee consisting of independent members appointed by the Governing Body. The Commission may add to the "voting section" no more than two delegates, and its decision is final and not subject to discussion or appeal.

The major problem is the issuance and presentation of credentials. Common rules applied to this issue are expected to lead to considerable administrative savings, both for States and for the Organization, through three related but independent proposals for the modification relating to the present routine requirement for the submission and examination of credentials. These proposals would: 
(a) Require the presentation of credentials only for certain treaty-making conferences, while eliminating this requirement for other types of conferences; the practice of requiring credentials, which originated at a time when long-range communications were such that it was not always possible to check whether a person appearing at an intergovernmental conference actually represented the authority that allegedly dispatched him, no longer has much relevance in an era of instant worldwide communications;

(b) Eliminate the need to establish a Credentials Committee, by transferring the most critical function of such a body - the examination of challenged credentials - to the General Committee while abolishing the function of routinely examining unchallenged credentials;

(c) Abolish the requirement for the automatic examination of all credentials, which frequently introduces an unnecessarily contentious element into a non-political conference, while retaining the possibility of challenging the participation of any delegation.

The unique tripartite composition of the ILO International Labor Conference causes special problems relating to approval of credentials. The claim has frequently been raised that certain Worker or Employer delegations are not representative. At the 2004 session, the International Labor Conference broadened the mandate of the credentials committee, on an interim basis, with a view to ensuring that delegations were independent and representative [9]. The Internet Governance Forum has no voting rights, but in case of extension of the mandate of the Forum, this issue seems to be timely.

\section{Conclusion}

In conclusion, we need to stress three points for consideration.

First, the multistakeholder approach reflects the same essence of the Internet as a network of networks. The three levels of Internet Governance and their interconnection demonstrate that the Internet is supranational. This principally differs from the traditional model of governance, where all stakeholders acting on the Internet are subordinated to national governments, as it is demonstrated on Figure 1.

Second, the ILO case shows us respective and effective decision-making of an international body under the auspices of the United Nations which is composed not only of governmental delegates. The same model could be applied to the Internet Governance Forum in case its mandate is extended in 2016. The IGF has most of features of an international organization, such as secretariat, the MAG as an executive body, and the Forum itself as quasi-plenary body.

Third, we need to have a universal instrument regulating human rights on the Internet. The brightest example is the charter of human rights and principles on the Internet drafted by the Internet Rights \& Principles Coalition on the IGF. It has the potential to be the online equivalent of the Universal Declaration of Human Rights but it is not acting even as a soft-law instrument because of the absence of decision-making capability of the Forum. In addition, different national legislations and the issue of jurisdiction could prove that we are in the great need of different international instruments in the sphere of internet governance.

\section{References}

1. World Summit on the Information Society (2005) Tunis agenda for the information society, WSIS-05/TUNIS/DOC/6(Rev. 1)-E (18 November 2005)

2. United Nations (2004) Information and communications technologies for development, A/RES/69/204 (19 December 2014).

3. Kurbalija J. (2014) An introduction to Internet Governance. DiploFoundation.

4. Gurumurthy G.K. (2008) Internet Governance and development agenda. Economic and Political Weekly, vol. 43, no. 14, pp. 19-23.

5. Kulesza J. (2012) International Internet law. Global Change, Peace \& Security, vol. 24, no. 3, pp. 351-364.

6. Jerbi S. (2012) Assessing the roles of multi-stakeholder initiatives in advancing the business and human rights agenda. International Review of the Red Cross, vol. 94, no. 887, pp. 1027-1046.

7. Maclolm J. (2013) Human rights on the Internet: Legal frames and technological implications. Statement on the workshop Human rights on the Internet: Legal frames and technological implications, issue 2 (eds. S.V. Maltseva, M.M. Komarov, A.A. Shcherbovich). Moscow: HSE, pp. 4-59.

8. Bowett D.W. (1982). The law of international institutions. 4th ed. London: Stevens \& Sons.

9. Sabel R. (2006) Procedure at international conferences. A study of the rules of procedure at the UN and at inter-governmental conferences. 2 nd ed. Cambridge: Cambridge University Press. 


\title{
Сущность и процессуальные аспекты мультистейкхолдер-подхода в управлении Интернетом
}

\section{А.А. Щербович}

кандидат юридических наук

преподаватель кафедры конституционного и административного права

Национальный исследовательский университет «Высшая школа экономики»

Адрес: 101000, г. Москва, ул. Мясницкая, д. 20

E-mail: ashcherbovich@hse.ru

\begin{abstract}
Аннотация
Система принятия решений в международных организациях по-прежнему весьма консервативна. Состав международных форумов, которые могут создавать значимые международные документы, не меняется на протяжении веков. Только дипломаты и представители международных организаций могут принимать юридически обязывающие решения на международном уровне. Форум по управлению Интернетом (Internet Governance Forum, IGF), созданный в 2006 году решением Всемирного саммита по информационному обществу, который является одним из наиболее авторитетных международных форумов по данному вопросу, не полностью использует свой потенциал для регулирования международных процессов управления Интернетом. Основой этого регулирования является мультистейкхолдер-подход, который состоит в множественности субъектов принятия решений, который включает в себя, в дополнение к традиционным категориям участников в лице государств и международных организаций, представителей гражданского общества, бизнеса, академического и технического сообществ, средств массовой информации и других заинтересованных сторон.

Данное исследование, как ожидается, может внести свой вклад в усовершенствование глобальных механизмов управления Интернетом, принимая во внимание интересы всех категорий участников, а также выработку правил процедуры принятия решений на основе мультистейкхолдер-подхода в управлении Интернетом, что позволило бы Форуму по управлению Интернетом принимать международные акты «мягкого права». Примером таких актов является проект Хартии прав и принципов в Интернете, разработанный Динамической коалицией IGF по правам человека и принципам в Интернете. Эта хартия - своего рода аналог Всеобщей декларации прав человека в отношении Интернета. Необходимость принятия документов по правам человека в Интернете определяет направление развития программ и политики глобального управления Интернетом и роли Форума по управлению Интернетом в этих процессах.
\end{abstract}

Ключевые слова: управление Интернетом, Форум по управлению Интернетом, мультистейкхолдеризм, права человека, Международная организация труда (МОТ), Организации Объединенных Наций.

Цитирование: Shcherbovich A.A. Multistakeholder approach and human rights in Internet Governance // Business Informatics. 2017. No. 1 (39). P. 7-13. DOI: 10.17323/1998-0663.2017.1.7.13.

\section{Литература}

1. Tunis agenda for the information society. WSIS-05/TUNIS/DOC/6(Rev. 1)-E (18 November 2005). World Summit on the Information Society, 2005.

2. Information and communications technologies for development. A/RES/69/204 (19 December 2014). United Nations, 2004.

3. Kurbalija J. An introduction to Internet Governance. DiploFoundation, 2014.

4. Gurumurthy G.K. Internet Governance and development agenda // Economic and Political Weekly. 2008. Vol. 43. No. 14. P. $19-23$.

5. Kulesza J. International Internet law // Global Change, Peace \& Security. 2012. Vol. 24. No. 3. P. 351-364.

6. 6. Jerbi S. Assessing the roles of multi-stakeholder initiatives in advancing the business and human rights agenda // International Review of the Red Cross. 2012. Vol. 94. No. 887. P. 1027-1046.

7. Maclolm J. Human rights on the Internet: Legal frames and technological implications (statement on the workshop) // Human rights on the Internet: Legal frames and technological implications. Issue 2 / Ed. by S.V. Maltseva, M.M. Komarov, A.A. Shcherbovich. Moscow: HSE, 2013. P. 4-59.

8. Bowett D.W. The law of international institutions. 4th ed. London: Stevens \& Sons, 1982.

9. Sabel R. Procedure at international conferences. A study of the rules of procedure at the UN and at inter-governmental conferences. 2nd ed. Cambridge: Cambridge University Press, 2006. 


\title{
A dynamic model for assessing nonproduction (labor) losses of an enterprise
}

\author{
Larisa A. Ismagilova \\ Professor, Head of Department of Business Economics \\ Ufa State Aviation Technical University \\ Address: 12, Karl Marx Street, Ufa, 450000, Russian Federation \\ E-mail: Ismagilova_ugatu@mail.ru
}

\section{Marina V. Frants}

Associate Professor, Department of Business Economics

Ufa State Aviation Technical University

Address: 12, Karl Marx Street, Ufa, 450000, Russian Federation

E-mail:tan-Marina@mail.ru

\section{Murat B. Kulmukhametov}

Doctoral Student, Institute of Social and Economic Research

Ufa Scientific Center of Russian Academy of Sciences

Address: 71, October Prospect, Ufa, 450000, Russian Federation

E-mail: murat.kulmuhametov@gmail.com

\begin{abstract}
The article deals with the problem of an enterprise's human resource management. An enterprise's human resources are described as a dynamic object of management with a great number of parameters specifying various aspects of its condition. The traditional techniques of human resources analysis are based, firstly, on retrospective analysis of data, and secondly, they take different aspects isolated from each other. The proposed managerial decisions are assessed from the point of view of their impact on separate parameters, but their synergetic effect is not assessed. These drawbacks may be eliminated through application of dynamic modelling including cognitive and flow modeling.

Cognitive modeling identifies mechanisms responsible for system reaction on managerial and disturbing influences. A cognitive map of the problem of human resources management was made which includes lots of feedback loops, both reinforcing and balancing. This means, the control object is characterized by nonlinear dynamics and counterintuitive behavior. These features make it difficult to predict object reaction on managerial and disturbing influences.

Within the overall issue of human resources management, this work reviews its particular aspect - the analysis of company's nonproduction losses due to temporary disability of employees. The temporary disability of an employee is understood as his/her temporary inability to perform job duties because of health condition of either himself/herself or his/her family members. The temporary disability is considered to be partially controlled by the enterprise. A flow model is elaborated for assessing a company's nonproduction losses caused by temporary disability of its employees, which can be used to optimize human resources management costs of an enterprise from the perspective of the cost-benefit ratio.
\end{abstract}

Key words: human resources management, dynamic modeling, cognitive map, flow modeling.

Citation: Ismagilova L.A., Frants M.V., Kulmukhametov M.B. (2017) A dynamic model for assessing nonproduction (labor) losses of an enterprise. Business Informatics, no. 1 (39), pp. 14-24.

DOI: 10.17323/1998-0663.2017.1.14.24. 


\section{Introduction}

$\mathrm{T}$ The importance of any company's human resources as the carrier and driver of innovations rises strongly in the knowledge-driven economy. This is why the task of efficiently managing the human resources becomes more and more urgent nowadays. This, in particular, explains the significant number of scientific publications on the subject matter.

Labor productivity is traditionally considered to be a key integral parameter describing the efficiency of human resources management. Quite a lot of scientific articles deal with comparative analysis of labor productivity in the Russian Federation and other countries of the world. Structural transformation and its implications for productivity growth in the BRICS countries from the 1980s onwards is studied in [1]. It is shown that relocation of labor across sectors is contributing to aggregative productivity growth in Russia. Lots of studies indicate that the Russia is lagging behind the developed countries in terms of the labor productivity [2-5]. According to the International Labor Organization, in 2010 Russia was the 60 -th in labor productivity worldwide; per capita (employed population) output came to US\$18,259 in this country, while the leading countries - the US, Hong-Kong and Ireland - recorded US $\$ 68,126$, US\$ 61,383 and US\$ 57,473 respectively [4]. From these numbers, we see that labor productivity in Russia was approximately three times lower than in the leading countries. Similar results have been obtained for the year 2012 when the labor productivity parameter (US\$/manhour) was calculated for Russia and the world's developed countries [5]. As per the calculations therein, Norway led in this parameter, with labor productivity at US\$ 88.08/manhour, while close results were shown by the US, Germany, France - US\$ 63.4, $62.16,63.46 /$ manhour respectively. In Russia this parameter reached just US\$24.97/manhour. It is noteworthy that the Russian "worktime fund (hour/man per year)" parameter is one of the highest $[5,6]$. In order to identify the reasons of low labor productivity in the RF and to search for tools to raise it, analysis has been done on the factors determining employees' motivation for productive labor. Special attention is paid to such factors as the situation in the labor market and the amount/differentiation of wages. It is noted that, given the low level of unemployment in the RF, shortage of personnel (both absolute and structural) is a burning issue. Low wages in general and very high differentiation of wages is another demotivating factor [5]. A systemic analysis of labor productivity in the RF as a whole and in its individual sectors has been done in [7]. This publica- tion explains the low labor productivity in the RF with the following reasons: inefficient organization of labor; nontransparent and excessive regulation; obsolete facilities and methods of manufacturing; rare use of the complex approach to planning territorial development; lack of professional skills; underdevelopment of the financial system; absence of incentives to raise labor productivity; structural peculiarities of the economy. We note that in that work the factor of inefficient labor organization in Russian companies is asserted as a most essential one, with its weight ranging sector-wise between $30 \%$ and $80 \%$. All of this determines the urgency of research in the management of companies' human resources.

An enterprise's human resources management includes an entire set of tasks, such as planning the need for skilled labor, search and employment of personnel, its adaptation, training and reskilling, arrangement of employees' working conditions and health care, setting up the system of material and moral incentives, etc.

The main task of human resources management is the steady supply of skilled personnel with such qualitative and quantitative characteristics as required for the company to achieve its goals with minimal staff costs. Therefore, any managerial decision in personnel development should be optimized and substantiated from the perspective of the cost-benefit ratio [8].

\section{Task definition}

An enterprises human resources may be described as a dynamic object of management with a great number of parameters specifying various aspects of its condition, such as availability of human resources in a particular time and situation, turnover of staff, reasonable structure of personnel in terms of age, gender, education and qualification, labor productivity and its impact on the enterprise's profitability, payroll rate, accident frequency rate, workplace discipline, employees' satisfaction level, employees' innovation activity, etc. It is important to note that the afore mentioned aspects are largely interconnected and interdependent and they determine organizationally the management objectives of the company's strategic development.

The traditional techniques of human resources analysis are based, as a rule, on retrospective analysis of data, and if they consider the aforementioned aspects over a period of time, they take them isolated from each other [9]. The proposed managerial decisions are assessed from the point of view of their impact on separate parameters, but their synergetic effect is not assessed. These drawbacks may be eliminated through application 
of dynamic modeling of the human resources analysis and the selection of efficient managerial decisions in the area of organizational control at an enterprise.

The system dynamics method is based on the idea that the complexity, unpredictability, counter-intuitivity of compound object dynamics is caused by multiple ties between its elements and their mutual influence. Hence, to forecast and control a compound object one needs to identify and describe those ties, first on a qualitative level by way of developing a cognitive map $[10,11]$ and then quantitatively, by way of developing a flow model [12, 13].

This work tackles the following problems:

1. Development of an enterprise's human resources management cognitive map to describe mutual influence of the features specifying various aspects of human resources status;

2. Development of a flow model to assess enterprise nonproduction losses due to the staff temporary disability.

3. Substantiation of managerial decisions on dynamic correction of nonproduction losses from temporary disability of employees.

\section{Proposed approach}

Figure 1 shows an enterprise's human resource management cognitive map allowing us to describe interrelations between the aspects noted above.

The cognitive map analysis demonstrates that the parameters specifying human resources of an enterprise are connected with a significant number of direct and feedback links which form several feedback loops, both amplifying and counterbalancing ones. The given cognitive map shows how tough it is to forecast the "reaction" of such system to any management action. As an example, let us assume the management of a company looks into raising the salary rate. Lower profitability of the company seems to be the most evident consequence of this, since the payroll is a component of costs. However, according to the cognitive diagram, a salary increase will also make possible lower staff turnover, a reasonable structure in terms of age, gender, education and qualification, higher productivity of labor and, through all of that, better profitability. Thus, on the one hand, a salary increase impairs profitability and, on the other hand, improves it.

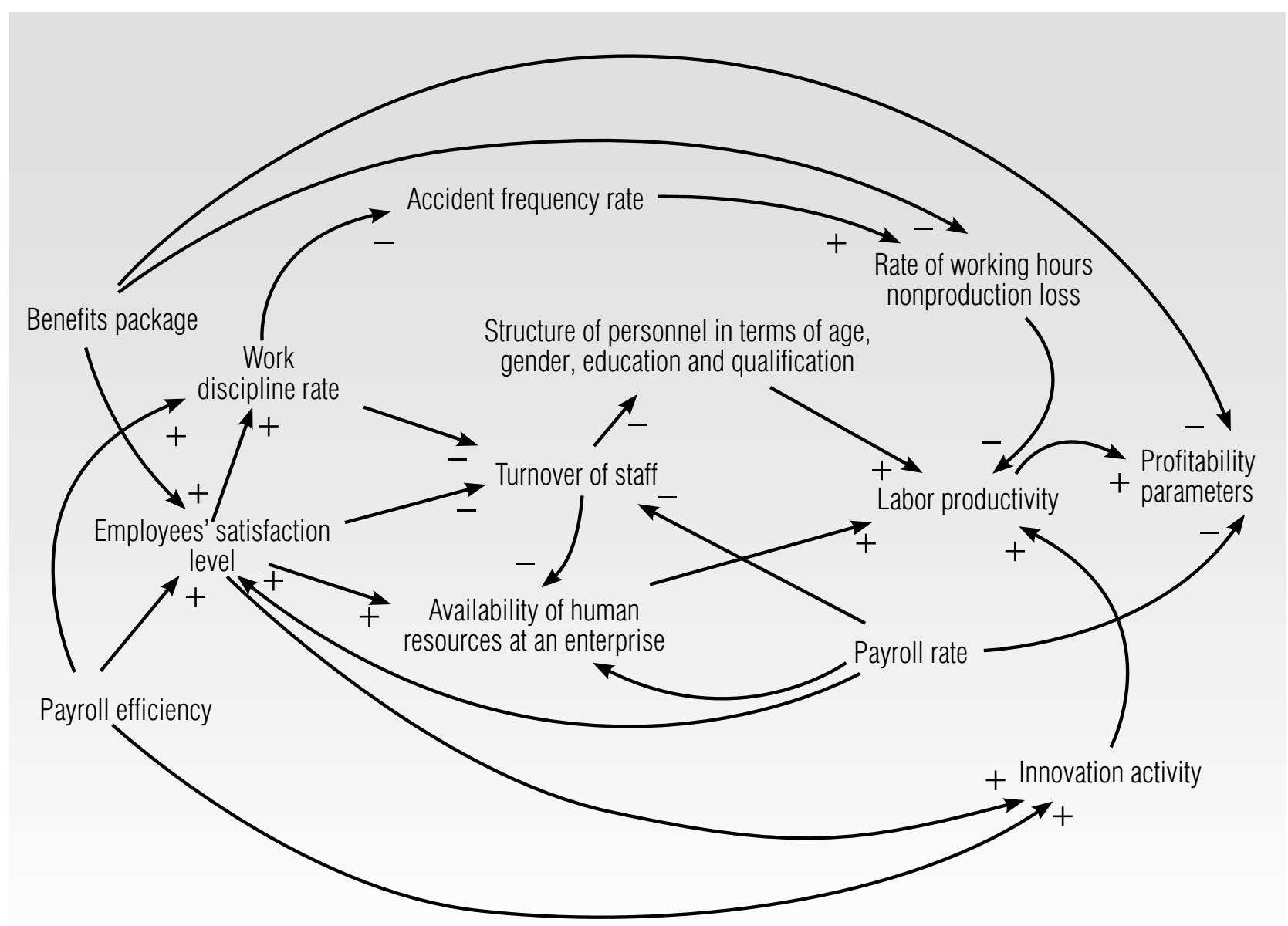

Fig. 1. Cognitive map of an enterprise's human resources management 
The cognitive map does not answer the question of how much quantitatively the profitability parameters will change in case of raising wages of employees, but it allows us to identify at the qualitative level the mechanisms which make up all other parameter responses to the salary increase. Unlike cognitive modeling having a qualitative character, the flow modeling allows quantitative forecasting of dynamics of the simulated object parameters both with and without certain managerial actions.

Within the overall issue of human resources management, this work reviews its particular aspect - the analysis of a company's nonproduction losses due to temporary disability of employees. The temporary disability of an employee is understood as his/her temporary inability to perform job duties because of health condition of either himself/herself or his/her family members. There may be singled out the following principal causes of temporary disability:

\ Employee's reporting sick due to newly or previously acquired disease. As a rule, such losses are more common with enterprises having either hazardous working conditions or predominantly female or older staff;

\ Employee's family member becoming sick which results in temporary absence due to nursing the sick family member. Such losses occur mostly at enterprises employing many women of reproductive age;

^ Workplace and home injuries happen more often with male employees at enterprises with higher level of danger or hazard.

As per the data by United Inter-departmental System of Information and Statistics (EMISS), the number of temporary disability cases in the RF is 60.2 per 100 employees, the average duration of disability is 12.7 days ( www.fedstat.ru). These numbers allow us to find out that worktime losses due to temporary disability of employees come to approximately $2-3 \%$ per annum, which poses a series of problems for companies:

1. While sick, an employee does not perform his/her job duties which company-wise results in underperformance versus production and sale plans. In this respect, seasonal infectious diseases are a particularly unfavorable factor, since they cause large-scale absences of employees from their working places.

2. Temporary disability caused by industrial accidents may lead to additional company expenses related to full or partial payment of medical treatment of the injured.

The temporary disability may be partially controlled by the enterprise. The management actions listed below may be singled out:
1. Prevention measures with regard to seasonal diseases, such as vaccination of employees to reduce the rate of seasonal infections.

2. Development of social and non-specific preventive care (assignment of health resort vouchers, distribution of multivitamins) to raise immunity and resistance of employees to various diseases;

3. Installation of indoor equipment to reduce aerial circulation of viruses and bacteria and restrict the spread of infectious diseases;

4. Labor safety and personnel training measures to reduce the industrial accident rate.

The flow model of assessing corporate losses caused by temporary staff disability is aimed at substantiating the organizational and managerial decisions in the human resources management. The primary focus is on temporary disability of employees during the intensive spread of seasonal viral infections.

\section{Description of the flow model assessing enterprise losses from staff's temporary disability}

\subsection{Purposes of the development}

1. Evaluation of an enterprise's nonproduction losses due to temporary disability of its employees.

2. Assessing the impact of managerial action on the size of enterprise nonproduction losses due to temporary disability of its employees.

\subsection{Basic assumptions of the model}

1. An employee's temporary disability may occur due to the following causes: seasonal infections; industrial accidents; other diseases. The temporary disability of an employee due to his/her family members' sickness is not addressed in the model.

2. The industrial accident rate is stable during the entire year, as well as the frequency of other diseases. Other diseases are considered non-infectious.

3. The seasonal infections rate is of a clear-cut seasonal nature. Infections are passed via contacts of the healthy with the infected. The contacts may occur both in the workplace and outside. The likeliness of contagion depends on the number of contacts a healthy employee has with infected colleagues and on the degree of infection spread outside.

4. The overall immunity rate is a variable value depending on the season. Absolute specific immunity develops after twice consecutively contracting a seasonal viral infection. 
It depends on the overall and specific immunity of an employee whether he/she gets infected or not.

5. The staff is permanent, i.e. nobody is dismissed or hired.

\subsection{A list of employee conditions from the point of view of working hour losses due to temporary disability of employees}

Pursuant to the model's objectives and assumptions, we determine a list of possible conditions of employees and the logic of transition from one condition to another.

An employee condition is described with the following sequence of data:

$$
S=(Z, I, V, R),
$$

where $Z$ - health condition;

$I$ - the condition of specific immunity to seasonal infections;

$V-$ the ability to infect healthy employees upon contact;

$R-$ disability.

Health conditions $(Z)$ may take the following values: $-Z_{1}-$ healthy, has never been ill with a seasonal infection; $-Z_{2}-$ got infected with a seasonal infection for the first time;

$-Z_{3}-$ got ill with a seasonal infection for the first time;

$-Z_{4}-$ is ill with a seasonal infection for the first time;

$-Z_{5}$ - healthy after being ill with a seasonal infection once;

$-Z_{6}-$ got infected with a seasonal infection for the second time;

$-Z_{7}-$ got ill with a seasonal infection for the second time,

$-Z_{8}-$ is ill with a seasonal infection for the second time;

$-Z_{9}$ - healthy after being ill with a seasonal infection twice;

$-Z_{10}-$ injured, has never been ill with a seasonal infection;

$-Z_{11}-$ sick with other diseases, has never been ill with a seasonal infection;

$-Z_{12}-$ injured, was ill with a seasonal infection once;

$-Z_{13}-$ sick with other diseases, was ill with a seasonal infection once;

$-Z_{14}$ - injured, was ill with a seasonal infection twice;

$-Z_{15}$ - sick with other diseases, was ill with a seasonal infection twice.

The condition of specific immunity to seasonal infections $(I)$ is related to the degree of social protection of employees. It may take the following values:

$-I_{0}-$ no specific immunity to a seasonal infection;
$-I_{1}-$ existing specific immunity to seasonal infections.

The ability to infect healthy employees by a contact $(V)$ is determined by organizational peculiarities of the working process and may take the following values:

$-V_{0}-$ not able to infect other employees;

$-V_{1}-$ able to infect other employees.

Disability $(R)$ may take the following values:

$-R_{0}-$ does not perform job duties,

$-R_{1}-$ performs job duties.

For the sake of brevity, we will designate the employee condition as $S_{z, i, v, r}$, where $z$ - the $Z$ value number, $i-$ the $I$ value number, $v$ - the $V$ value number, $r$ - the $R$ value number. For example, condition $S_{1,0,0,1}$ is described as: healthy, has not been sick with a seasonal infection; has no specific immunity to seasonal infection, not able to infect other employees, keeps performing job duties. Since the components specifying the employee's condition are not independent, not all of their combinations are possible. Let us list the possible conditions: $S_{1,0,0,1}$, $S_{2,0,0,1}, S_{3,0,1,1}, S_{4,0,0,0}, S_{5,0,0,1}, S_{6,0,0,1}, S_{7,0,1,1}, S_{8,0,0,0}, S_{9,1,0,1,}$ $S_{10,0,0,0}, S_{11,0,0,0}, S_{12,0,0,0}, S_{13,0,0,0}, S_{14,1,0,0}, S_{15,1,0,0}$. Thus, at any moment of time an employee may be in one of the 15 conditions.

The employee condition and transition graph is shown in Figure 2.

\subsection{Equations of the model}

The model equations use the following designations:

$L_{i}(t)$ - number of employees in an $i$-th condition $(i=1, \ldots, 15)$ at the $t$ moment of time;

$\lambda_{i, j}(t)$ - intensity of transition of employees from an $i$-th condition to a $j$-th condition;

$J_{i}^{-}$- set of indices of conditions in which there exists a transition from an $i$-th condition;

$J_{i}^{+}$- set of indices of conditions from which there exists a transition to an $i$-th condition.

Then the dynamics of staff number in various conditions is described with a system of 15 finite-difference equations of the following type:

$L_{i}(t+1)=L_{i}(t)-\sum_{j \in J_{i}} \lambda_{i, j}(t) \cdot L(t)+\sum_{j \in J_{i}^{+}} \lambda_{i, j}(t) \cdot L(t) .(1)$

The evaluation of an enterprise's losses from temporary disability of employees is built on the dynamics of number of employees in different conditions.

Enterprise losses $T$ (in man days) due to temporary disability of employees for an interval of time $\left(t_{1}, t_{2}\right)$ are calculated by formula (2): 


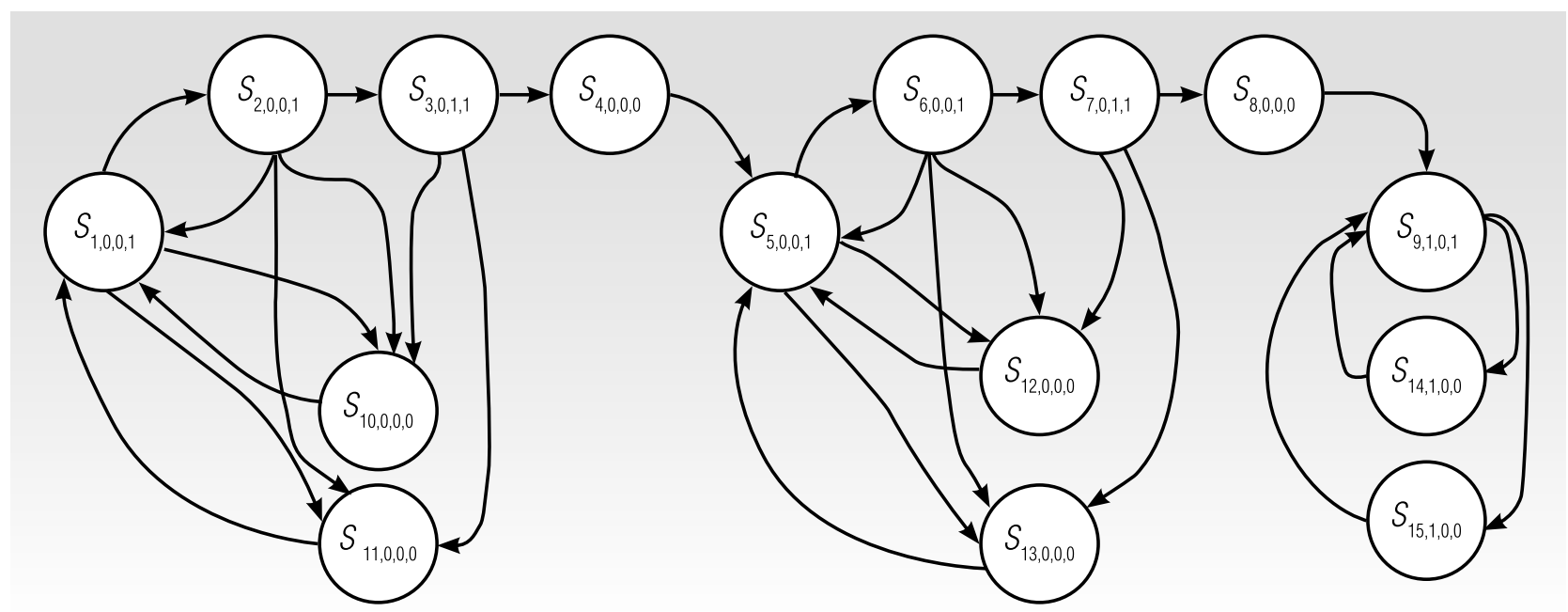

Fig. 2. Employee condition and transition graph

$$
T\left(t_{1}, t_{2}\right)=\sum_{t=t_{1}}^{t_{2}} \sum_{j \in J_{h}} L_{j}(t)
$$

In formula (2), $J_{n}$ is a set of indices of conditions where the employee is absent from work, $J_{n}=\{4,8,10,11,12$, $13,14,15\}$.

Accordingly, enterprise losses $D$ due to temporary disability of employees for an interval of time $\left(t_{1}, t_{2}\right)$ are calculated by the formula:

$$
D\left(t_{1}, t_{2}\right)=\bar{V} \cdot T\left(t_{1}, t_{2}\right) .
$$

In formula (3), $\bar{V}$ is the average labor productivity of the enterprise's employees. It is calculated as the ratio of the enterprise's annual receipts to the actually fulfilled man-days per year.

The intensity of transitions between conditions is determined with regard to intensity of disease spread.

$\lambda_{1,2}(t), \lambda_{5,6}(t)$ are the intensities of infecting healthy employees without immunity to seasonal viral infections. They are calculated by the formula:

$$
\lambda_{1,2}(t)=\lambda_{5,6}(t)=m \cdot\left(k_{1} \cdot p_{1}(t)+k_{2} \cdot p_{2}(t)\right) .
$$

Formula (4) uses the following designations:

$m$ - probability of infecting in case of contact with an infected or sick person at workplace or outside;

$k_{1}$ - average intensity of employee's contacts at workplace;

$p_{1}(t)$ - probability of a contact with an infected employee; it is determined as the ratio of infected employees to those capable of working, i.e. by the formula:

$p_{1}(t)=\frac{L_{3}(t)+L_{7}(t)}{L_{1}(t)+L_{2}(t)+L_{3}(t)+L_{5}(t)+L_{6}(t)+L_{7}(t)+L_{9}(t)}$, where $k_{2}$ - average intensity of employee's contacts with other people outside the workplace;

$p_{2}(t)-$ probability of contact with an infected or sick person outside the workplace. It is determined in accordance with the data on seasonal infection dynamics in the region.

The rest of intensities are constant values.

Intensities $\lambda_{2,1}$ and $\lambda_{6,5}$ are equal and are calculated by the formula:

$$
\lambda_{2,1}=\lambda_{6,5}=\frac{\operatorname{Im}}{\tau_{\text {in }}}-\lambda_{2,10}-\lambda_{2,11}
$$

Intensities $\lambda_{2,3}$ and $\lambda_{6,7}$ are also equal and are calculated by the formula:

$$
\lambda_{2,3}=\lambda_{6,7}=\frac{(1-\operatorname{Im})}{\tau_{i n}}-\lambda_{2,10}-\lambda_{2,11}
$$

In formulas (6) and (7), $\tau_{\text {in }}$ is the average duration of the infecting period; $I m$ is a number from 0 to 1 , reflecting the state of immunity of employees at an enterprise.

Intensities $\lambda_{10,1}, \lambda_{12,5}, \lambda_{14,9}$ are equal and are calculated by the formula:

$$
\lambda_{10,1}=\lambda_{12,5}=\lambda_{14,9}=\frac{1}{\tau_{t r}} .
$$

In formula (8), $\tau_{t r}$ is the average duration of an injured employee's sick leave.

Intensities $\lambda_{11,1}, \lambda_{13,5}, \lambda_{15,9}$ are equal and are calculated by the formula:

$$
\lambda_{11,1}=\lambda_{13,5}=\lambda_{15,9}=\frac{1}{\tau_{p b}} .
$$


The relationship between the parameters of the simulation and management impact

\begin{tabular}{|c|c|c|}
\hline $\begin{array}{l}\text { Management } \\
\text { targets }\end{array}$ & Management actions & $\begin{array}{l}\text { Simulation } \\
\text { parameters }\end{array}$ \\
\hline $\begin{array}{l}\text { Reducing susceptibility } \\
\text { of employees } \\
\text { to seasonal viral } \\
\text { infections }\end{array}$ & $\begin{array}{l}\text { - organizational and educational activity for the free vaccination of employees; } \\
\text { - the enrichment of nutrition with vitamins; } \\
\text { - providing preventive and curative services to employees in the medical departments of the } \\
\text { enterprise; } \\
\text { - full or partial payment of diagnostic, preventive, health services as a part of a social package } \\
\text { of enterprise }\end{array}$ & $m, I m$ \\
\hline $\begin{array}{l}\text { Impeding the spread } \\
\text { of infection }\end{array}$ & $\begin{array}{l}\text { - installation of equipment for air purification and ventilation in the premises of the enterprise; } \\
\text { - minimizing the number of meetings with the participation of a large number of employees in period } \\
\text { of active proliferation of seasonal viral infections; } \\
\text { - encouraging employees to take sick leave }\end{array}$ & $k_{1}, m$ \\
\hline $\begin{array}{l}\text { Reducing the overall } \\
\text { incidence among the } \\
\text { enterprise's employees }\end{array}$ & $\begin{array}{l}\text { - including voluntary health insurance programs in the social package of the enterprise; } \\
\text { - carrying out regular medical examinations of employees; } \\
\text { - equipping workplaces with equipment protecting against harmful environment factors; } \\
\text { - the enrichment of nutrition with vitamins }\end{array}$ & $\begin{array}{l}\lambda_{1,11}, \lambda_{2,11}, \lambda_{3,11} \\
\lambda_{5,13}, \lambda_{6,13}, \lambda_{7,13} \\
\lambda_{9,15}\end{array}$ \\
\hline $\begin{array}{l}\text { Reducing workplace } \\
\text { injuries }\end{array}$ & $\begin{array}{l}\text { - assessment of the workplaces; } \\
\text { - rational schedule of working day including special time for rest and nutrition; } \\
\text { - technical re-equipment of outdated production facilities, installation of protective screens, barriers }\end{array}$ & $\begin{array}{l}\lambda_{1,10}, \lambda_{2,10}, \lambda_{3,10} \\
\lambda_{5,12}, \lambda_{6,12}, \lambda_{7,12} \\
\lambda_{9,14}\end{array}$ \\
\hline
\end{tabular}

In formula (9), $\tau_{p b}$ is the average duration of a sick leave due to other diseases.

Intensities $\lambda_{3,4}, \lambda_{7,8}$ are equal and are calculated by the formula:

$$
\lambda_{3,4}=\lambda_{7,8}=\frac{1}{\tau_{z r}} .
$$

In formula (10), $\tau_{z r}$ is the average duration of infection period.

Intensities $\lambda_{4,5}, \lambda_{8,9}$ are equal and are calculated by the formula:

$$
\lambda_{4,5}=\lambda_{8,9}=\frac{1}{\tau_{s i}} .
$$

In formula (11), $\tau_{s i}$ is the average duration of a sick leave due to a seasonal infection.

The influence of management actions on the value of nonproduction losses from temporary disability of employees is measured through changing simulation parameters. The relationship between the parameters of the simulation and management impacts is given in Table 1 .

\section{Testing the model}

The model was tested in the Ufa Engine Industrial Association company, located in the Republic of Bashkortostan (www.umpo.ru). The purpose of the simulation was to evaluate the nonproduction losses of the enterprise associated with seasonal viral infections, as well as analysis of the effectiveness of management decisions aimed at reducing losses.

Ufa Engine Industrial Association is a large enterprise engaged in the development, production and after-sales service of gas-turbine engines for military aircraft. The number of employees exceeds 20,000. The enterprise is not classified as a company with hazardous working conditions. Since January 2006, a social package has been introduced, and the money may be used to pay for preventive and medical services, services of sports and fitness. Caring for the health of workers is an integral part of the social program of the enterprise. The company has its own recreation centers with services aimed at year-round recreation and health recovery of employees. 
An estimation of model parameters was carried out with the use of enterprise data, regional and industrial statistics as well as on the basis of analytical materials devoted to seasonal viral infections. The following settings were used: the time step is equal to 1 day, the unit for time is the Day, the initial time is equal to zero, the final time is equal to 365 . All simulation parameters were calculated according to the selected unit of measurement.

To assess such simulation parameters as the average time of incubation, the average time of infection, the average duration of sick leave due to the seasonal infection, the data of the websites of National Pulmonary Fund (www.legkie.org) and Influenza Research Institute (www.influenza.spb.ru) were used. According to these data, the incubation period for respiratory viral infection lasts from 1 to 3 days. The respiratory viral infection patient is most infectious to others for 2-3 days. Then the rate of viral replication in the body of the sick persons is greatly reduced, but the release of the virus into the environment may continue for up to 2 weeks. The total duration of respiratory viral infection is up to 14 days. However, most people recover in a period from 7 to 10 days. In this regard, in the calculations, the following values of the parameters were used: $\tau_{i n}=3$ days, $\tau_{z r}=2$ days, $\tau_{s i}=10$ days.

In order to estimate transition intensities to the states $S_{10,0,0,0}, S_{12,0,0,0}, S_{14,1,0,0}$ (the following parameters: $\lambda_{1,10}$, $\left.\lambda_{2,10}, \lambda_{3,10}, \lambda_{5,12}, \lambda_{6,12}, \lambda_{7,12}, \lambda_{9,14}\right)$ the data of the website of Federal State Statistic Service of Russian Federation (www.gks.ru) were used. According to these data, the average number of employees in the industry "Manufacture of machines and equipment" in the year 2015 was 781,031 people, the number of injured at work to incapacity for 1 day or more and with a fatal outcome was 1,369 people. Consequently, the intensities of the transitions in the states $S_{10,0,0,0}, S_{12,0,0,0}, S_{14,1,0,0}$ are equal to 0.0000048 . The number of man-days of disability of injured at work to incapacity for 1 day or more and with a fatal outcome is 62,179 . On this basis, the average duration of incapacity for work due to occupational injuries is 45.4 days (the parameter $\tau_{t r}$ ).

To assess transition intensities to the states $S_{11,0,0,0}$, $S_{13,0,0,0}, S_{15,1,0,0}$ (the following parameters: $\lambda_{1,11}, \lambda_{2,11}, \lambda_{3,11}$, $\left.\lambda_{5,13}, \lambda_{6,13}, \lambda_{7,13}, \lambda_{9,15}\right)$ the data on total incidence rates and temporary disability of the population of the Republic of Bashkortostan in the year 2015 were used as shown on the website of the Federal State Statistic Service of Russian Federation (www.gks.ru). On this basis, transi- tion intensities to the states $S_{11,0,0,0}, S_{13,0,0,0}, S_{15,1,0,0}$ in the simulation are equal to 0.000821 .

\section{Model implementation}

A flow model has been implemented in the VenSim PLE package (https://vensim.com). The advantages of this package which predetermined its choice as a modeling environment are: convenient intuitive interface, support both cognitive and flow modeling, free of charge for use in academic purposes, the ability to export simulation results.

As an example, let us see the results of two model simulations held to assess preventive measures aimed at raising the overall immunity of an enterprise's staff. The model parameter Im, which reflects the state of overall immunity of employees, was calculated by formula (12) in the first experiment and by formula (13) in the second:

$$
\begin{gathered}
I m=\left\{\begin{array}{c}
0.5 \text { from week } 36 \text { till week } 45 \\
0.53 \text { otherwise }
\end{array}\right. \\
I m=\left\{\begin{array}{c}
0.6 \text { from week } 36 \text { till week } 45 \\
0.63 \text { otherwise }
\end{array}\right.
\end{gathered}
$$

As can be seen from the formulas, the immunity rate in the second simulation is better than in the first, which reflects the influence of preventive measures. The immunity deterioration in the period from week 36 till week 45 in both experiments reflects a known biological pattern that, according to medical data, at that time (late winter - early spring) most of people have worse immunity than at any other time of year (www.influenza. spb.ru).

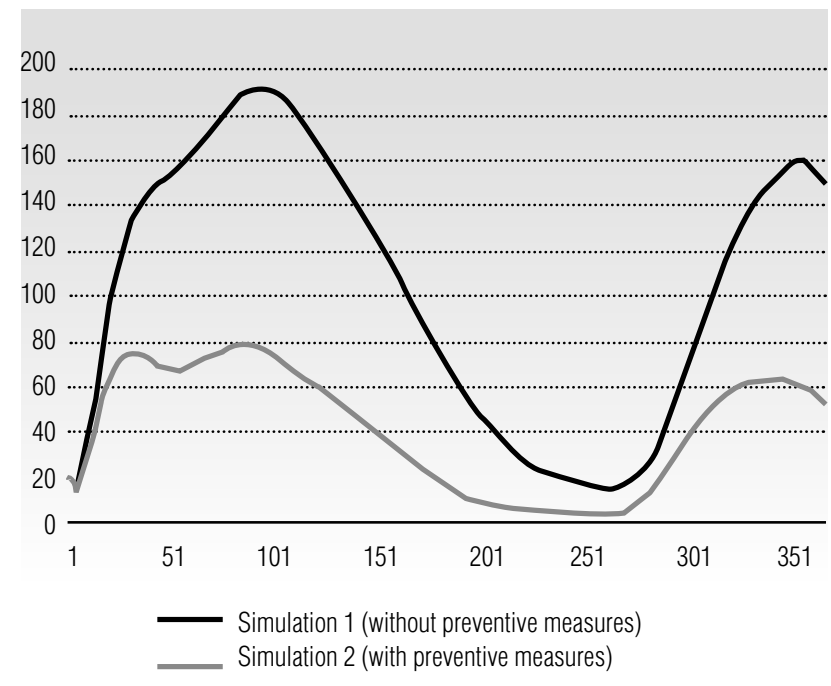

Fig. 3. Number of enterprise employees temporarily out of job duties because of a seasonal viral infection 
The rest of the parameters were the same in both simulations.

Figure 3 shows the dynamics of the number of an enterprise staff who are temporarily not performing their job duties because of falling ill to a seasonal viral infection.

As can be seen from Figure 3, preventive measures to raise overall immunity can significantly relieve the problem of massive absence from workplaces during seasonal viral epidemics.

\section{Conclusion}

Cognitive modeling is used in this work to structure the issue of human resources management at an en- terprise. Analysis of the cognitive map has shown that the parameters specifying human resources of an enterprise are connected by a significant number of direct and feedback links, both amplifying and counterbalancing ones. This predetermines the complexity of forecasting and assessing the efficiency of managerial decisions in human resources management.

This work offers a flow model which allows one to evaluate the nonproduction losses of an enterprise caused by temporary disability of its employees. It is shown that on the basis of this model it is possible to review the efficiency of managerial actions, such as vaccination of employees, non-specific prevention, installation of air treatment equipment, labor safety and efforts to improve work discipline.

\section{References}

1. Deconstructing the BRICs: Structural transformation and aggregate productivity growth / G.J. de Vries [et al.]. Journal of Comparative Economics, no. 40, pp. 211-227.

2. Vaisburd V.A., Simonova M.V., Bogatyreva I.V., Vanina E. G., Zheleznikova E.P. (2016) Productivity of labour and salaries in Russia: Problems and solutions. International Journal of Economics and Financial Issues, no. 6 (5), pp. $157-165$.

3. Lavrovskii B.L. (2015) Russian and world trends in productivity. Studies on Russian Economic Development, vol. 26, no. 3, pp. 278284.

4. Kardashevskiy V.V.,AmirovA.G. (2012) Proizvoditel'nost' truda:problemy i perspektivy razvitiya [Labour productivity: problemsand perspectives of development]. Labour Safety and Economics, no. 4 (9), pp. 81-88 (in Russian).

5. Chekmarev O.P.(2015) Motivatsiya povysheniya proizvoditel'nostitruda naemnykh rabotnikov: faktory defitsita kadrov, razmerai differentsiatsiioplaty truda [Employees motivation on increasing labourproductivity: deficit oflabourforce, wage size and differentiation]. Proceedings of Saint Petersburg State Agrarian University, no. 38, pp. 184-190 (in Russian).

6. Zolotov A.V., Mazur O.A., Popov M.V. (2015) Dynamics of labour input and average annual hours actually worked per worker in industry of developed countries and Russia: Similarities and differences. Asian Social Science, vol. 11, no. 14, pp. 205-210.

7. McKinsey Global Institute (2009) Effektivnaya Rossiya:proizvoditel'nost' kak fundament rosta [Effective Russia:labourproductivity as a basis of growth]. Russian Management Journal, vol. 7, no. 4, pp. 109-168 (in Russian).

8. Ismagilova L.A., Gileva T.A. (2006) Sotsial'nye investitsii v razvitie chelovecheskogo kapitala predpriyatiya: obosnovanie i otsenka [Social investments for human capital development: study and evaluation]. St. Petersburg State Polytechnical University Journal. Economics, no. 48-2, pp. 153-158 (in Russian).

9. Savitskaya G.V.(2016). Analizkhozyaystvennoy deyatel'nostipredpriyatiya [Analysis of economic activities of an enterprise]. Moscow: INFRA-M (in Russian).

10. Avdeeva Z.K., Kovriga S.V., Makarenko D.I., Maksimov V.I. (2007) Kognitivnyy podkhod v upravlenii [Cognitive approach in management]. Control Sciencies, no. 3, pp. 2-8 (in Russian).

11. Abramova N.A. (2007) O probleme riskov iz-za chelovecheskogo faktora v ekspertnykh metodakh i informatsionnykh tekhnologiyakh [The problem of the risks due to human factors in the expertise methods and information technologies]. Control Sciencies, no. 2, pp. 11-21 (in Russian).

12. Sterman J. (2000). Business dynamics: systems thinking and modeling for a complex world. McGraw-Hill.

13. Katalevskii D.Yu. (2015) Osnovy imitatsionnogo modelirovaniya i sistemnogo analiza v upravlenii [Fundamentals of management simulation modeling and system analysis]. Moscow: Delo, RANEPA (in Russian). 


\section{Динамическая модель оценки непроизводственных (трудовых) потерь предприятия}

\section{Л.А. Исмагилова}

доктор технических наук, профессор, заведующая кафедрой экономики предпринимательства Уфимский государственный авиационный технический университет Адрес: 450000, г. Уфа, ул. К. Маркса, д. 12

E-mail: Ismagilova_ugatu@mail.ru

\section{М.В. Франц}

кандидат технических наук, доцент кафедры экономики предпринимательства Уфимский государственный авиационный технический университет Адрес: 450000, г. Уфа, ул. К. Маркса, д. 12

E-mail:tan-Marina@mail.ru

\section{М.Б. Кульмухаметов}

аспирант, Институт соииально-экономических исследований Уфимский научный центр Российской академии наук Адрес: 450000, г. Уфа, проспект Октября, д. 71

E-mail: murat.kulmuhametov@gmail.com

\section{Аннотация}

Статья посвящена проблеме управления трудовыми ресурсами на предприятии. Трудовые ресурсы рассматриваются как динамический объект управления, характеризующийся большим количеством показателей, отражающих отдельные аспекты его состояния. Традиционные методики анализа трудовых ресурсов, во-первых, носят ретроспективный характер, а вовторых, рассматривают отдельные аспекты управления трудовыми ресурсами изолированно друг от друга. Предлагаемые управленческие решения оцениваются с точки зрения их влияния на отдельные показатели, но не оценивается их синергетический эффект. Для преодоления указанных недостатков предлагается использовать метод динамического моделирования, включающий когнитивное и потоковое моделирование.

Когнитивное моделирование позволяет идентифицировать механизмы, формирующие реакцию системы на управленческие и возмущающие воздействия. В работе представлена когнитивная карта проблемы управления трудовыми ресурсами, включающая значительное число усиливающих и уравновешивающих контуров обратных связей. Это означает, что рассматриваемый объект управления характеризуется такими свойствами, как нелинейность динамики и противоинтуитивность поведения. Описанные особенности обуславливают сложность прогнозирования его реакции на управленческие и возмущающие воздействия.

Также в работе в рамках общей проблемы управления трудовыми ресурсами рассматривается ее отдельный аспект - анализ непроизводственных потерь предприятия от временной нетрудоспособности работников. Под временной нетрудоспособностью работника понимается его неспособность временно исполнять трудовые обязательства в связи с состоянием здоровья или самого работника, или членов его семьи. Временная нетрудоспособность работников рассматривается как параметр, частично управляемый со стороны предприятия. В работе описана потоковая модель оценки непроизводственных потерь предприятия от временной нетрудоспособности его работников, в которой внимание фокусируется на временной нетрудоспособности работников в период активного распространения сезонных вирусных инфекций. Предложенная модель может быть использована для оптимизации затрат предприятия на управление трудовыми ресурсами с точки зрения соотношения затрат и результатов.

Ключевые слова: управление трудовыми ресурсами, динамическое моделирование, когнитивная карта, потоковое моделирование. 
Цитирование: Ismagilova L.A., Frants M.V., Kulmukhametov M.B. A dynamic model for assessing nonproduction (labor) losses of an enterprise // Business Informatics. 2017. No. 1 (39). P. 14-24. DOI: $10.17323 / 1998-0663.2017 .1 .14 .24$.

\section{Литература}

1. Deconstructing the BRICs: Structural transformation and aggregate productivity growth / G.J. de Vries [et al.] // Journal of Comparative Economics. 2012. No. 40. P. 211-227.

2. Productivity of labour and salaries in Russia: Problems and solutions / V.A. Vaisburd [et al.] // International Journal of Economics and Financial Issues. 2016. No. 6 (5). P. 157-165.

3. Lavrovskii B.L. Russian and world trends in productivity // Studies on Russian Economic Development. 2015. Vol. 26. No. 3. P. $278-284$.

4. Кардашевский В.В., Амиров А.Г. Производительность труда: проблемы и перспективы развития // Охрана и экономика труда. 2012. № 4 (9). С. 81-88.

5. Чекмарев О.П. Мотивация повышения производительности труда наемных работников: факторы дефицита кадров, размера и дифференциации оплаты труда // Известия Санкт-Петербургского государственного аграрного университета. 2015 . № 38. C. $184-190$.

6. Zolotov A.V., Mazur O.A., Popov M.V. Dynamics of labour input and average annual hours actually worked per worker in industry of developed countries and Russia: Similarities and differences // Asian Social Science. 2015. Vol. 11. No. 14. P. 205-210.

7. Эффективная Россия: производительность как фундамент роста / McKinsey Global Institute // Российский журнал менеджмента. 2009. T. 7. № 4. C. 109-168.

8. Исмагилова Л.А., Гилева Т.А. Социальные инвестиции в развитие человеческого капитала предприятия: обоснование и оценка // Научно-технические ведомости Санкт-Петербургского государственного политехнического университета. Экономические науки. 2006. № 48-2. С. 153-158.

9. Савицкая Г.В. Анализ хозяйственной деятельности предприятия: учебное пособие. Москва: ИНФРА-М, 2016.

10. Когнитивный подход в управлении / 3.К. Авдеева и [др.] // Проблемы управления. 2007. № 3. С. 2-8.

11. Абрамова Н.А. О проблеме рисков из-за человеческого фактора в экспертных методах и информационных технологиях // Проблемы управления. 2007. № 2. С. 11-21.

12. Sterman J. Business dynamics: systems thinking and modeling for a complex world. McGraw-Hill, 2000.

13. Каталевский Д.Ю. Основы имитационного моделирования и системного анализа в управлении: учебное пособие. М.: Дело, РАНХиГС, 2015. 


\title{
Model for organizing cargo transportation with an initial station of departure and a final station of cargo distribution ${ }^{1}$
}

\author{
Nerses K. Khachatryan \\ Senior Researcher, Laboratory of Dynamic Models of Economy and Optimization \\ Central Economics and Mathematics Institute, Russian Academy of Sciences; \\ Associate Professor, Department of Business Analytics \\ National Research University Higher School of Economics \\ Address: 47, Nakhimovsky Prospect, Moscow, 117418, Russian Federation \\ E-mail:nerses@cemi.rssi.ru;nkhachatryan@hse.ru
}

\section{Andranik S. Akopov}

Professor, Department of Business Analytics

National Research University Higher School of Economics

Address: 20, Myasnitskaya Street, Moscow, 101000, Russian Federation

E-mail:aakopov@hse.ru

Abstract

A model for organizing cargo transportation between two node stations connected by a railway line which contains a certain number of intermediate stations is considered. The movement of cargo is in one direction. Such a situation may occur, for example, if one of the node stations is located in a region which produce raw material for manufacturing industry located in another region, and there is another node station. The organization of freight traffic is performed by means of a number of technologies. These technologies determine the rules for taking on cargo at the initial node station, the rules of interaction between neighboring stations, as well as the rule of distribution of cargo to the final node stations. The process of cargo transportation is followed by the set rule of control. For such a model, one must determine possible modes of cargo transportation and describe their properties.

This model is described by a finite-dimensional system of differential equations with nonlocal linear restrictions. The class of the solution satisfying nonlocal linear restrictions is extremely narrow. It results in the need for the "correct" extension of solutions of a system of differential equations to a class of quasisolutions having the distinctive feature of gaps in a countable number of points. It was possible numerically using the Runge-Kutta method of the fourth order to build these quasi-solutions and determine their rate of growth. Let us note that in the technical plan the main complexity consisted in obtaining quasisolutions satisfying the nonlocal linear restrictions. Furthermore, we investigated the dependence of quasi-solutions and, in particular, sizes of gaps (jumps) of solutions on a number of parameters of the model characterizing a rule of control, technologies for transportation of cargo and intensity of giving of cargo on a node station.

Key words: organizing cargo transportation, dynamic model, differential equations, solution of the traveling wave type, numerical realization.

Citation: Khachatryan N.K., Akopov A.S. (2017) Model for organizing cargo transportation with an initial station of departure and a final station of cargo distribution. Business Informatics, no. 1 (39), pp. 25-35.

DOI: 10.17323/1998-0663.2017.1.25.35.

${ }^{1}$ This work was supported by the Russian Foundation for Basic Research (project No. 16-01-00110) 


\section{Introduction}

$\mathrm{R}$ esearch has been is devoted to the problem of organizing cargo transportation; in particular, it is considered in works [1-7]. In [8-10] a model devoted to studying the process of organizing cargo transportation realized through a number of technologies is investigated. The distinctive feature of this model is studying the modes of cargo transportation satisfying the set "simple" control system. Several variants of the model are considered.

The first version describes transnational transportation, i.e. transportation without a selected initial station of departure and a final station of distribution of cargo. This version of the model is given by a countable system of differential equations with nonlocal linear restrictions:

$$
\begin{gathered}
\dot{z}_{i}(t)=\alpha z_{i-1}-2 \alpha z_{i}+\alpha z_{i+1}+\varphi\left(z_{i}\right), i \in Z, t \in[0,+\infty), \\
z_{i}(t)=z_{i+1}(t+\tau), i \in Z, t \in[0,+\infty),
\end{gathered}
$$

where $z_{i}(t)$ - the number of the involved nodes at the station with number $i$ in timepoint $t$;

$\tau$ - the characteristic of control.

Definition 1. The family of absolutely continuous functions $\left\{z_{i}(.)\right\}_{i \in Z}$, defined on $[0,+\infty)$, It called the decision of the system of differential equations (1), if almost all $t \in[0,+\infty)$ functions $z_{i}($.) satisfy this system.

Solutions of the system of differential equations (1), satisfying the condition (2) are called solutions of the traveling wave type. The theorem of existence and uniqueness of solutions of traveling wave type is proven. From the substantive point of view, this theorem describes a possible mode of cargo transportation at the quantity of the involved nodes recorded in the initial time point on a randomly selected station.

The second version describes transportation with a selected initial station of departure of the cargo. This version of the model is given by the countable system of differential equations with nonlocal linear constraints:

$$
\begin{gathered}
\dot{z}_{0}(t)=\psi(t)-\alpha z_{0}+\alpha z_{1}+\varphi_{0}\left(z_{0}\right), t \in[0,+\infty), \\
\dot{z}_{i}(t)=\alpha z_{i-1}-2 \alpha z_{i}+\alpha z_{i+1}+\varphi\left(z_{i}\right), i=1,2, \ldots, t \in[0,+\infty), \\
z_{i}(t)=z_{i+1}(t+\tau), i=0,1,2, \ldots, t \in[0,+\infty) .
\end{gathered}
$$

Apparently, unlike system (1) - (2), the first equation is allocated here. The function participating in this equation describes the intensity of handover of cargo on the initial station. As it appeared, the class of solutions of system (3) - (5) is extremely narrow. This leads to the need to "correct" the extension of the class of solutions of the traveling wave type to the class "quasi-travelling" wave type.

Definition 2. The family of piecewise absolutely continuous functions $\left\{z_{i}(.)\right\}_{0}^{+\infty}$, defined on $[0,+\infty)$, it called a quasi-solution of thetraveling wave type with characteristic $\tau>0$ for the system (3) - (5), if almost all $t \in[0,+\infty)$ functions $z_{i}($.$) satisfy the system, and gaps are located at$ the points $k \tau, k=1,2, \ldots$.

It should be noted that another possible way to expand the class of traveling wave type solutions to the class of "quasi-traveling" wave type solutions making waves is the weakening of the nonlocal linear restrictions (5) (assuming implementation of these restrictions with some error). However, for these restrictions to define the control system at cargo transportation in this type of expansion is unacceptable as the control system (5) is the simplest and therefore realized.

The theorem of existence and uniqueness of the traveling wave type quasi-solution is proven. As follows from definition 2, quasi-solution components have gaps in points multiple $\tau$. This theorem also describes the possible mode of cargo transportation at the quantity of the involved nodes recorded in initial the time point at an arbitrary fixed station. However, unlike the previous version of the model, this mode of transportation involves a sharp change in the number of involved nodes (jumps) in time points multiple to the characteristic of the control system. Considering the small equipment of intermediate stations, a change of number of the involved nodes cannot be too big. This leads to the formulation of the problem of minimizing the magnitude of the jumps, depending on the parameters of the system, which is also solved.

The third version describes transportation between a dedicated initial station of departure and final station of distribution of cargo. This version of the model describes the cargo on the long section of the route between the two node stations. Unlike the first and second versions, this version of the model is described by a finite number of differential equations with nonlocal linear constraints. The class of solutions of this system is also very narrow, so, here, as well as for system (3) - (5), there is an expansion of a class of solutions of traveling-wave type to class of solutions of "quasi-traveling" wave type. As in the previous case, considering the small equipment of intermediate stations, a change of number of the involved nodes cannot be too big. This leads to the formulation of the problem of minimizing the magnitude of the jumps, depending on the parameters and the 
data of system, which is also solved. From the practical point of view, the numerical realization of this version of the model is very important. This work is devoted to this task. The numerical realization will allow us to investigate dependence of traveling-wave type quasi-solutions, and in particular the sizes of gaps (jumps) of solutions, from a number of parameters of model.

Before passing on to the description of the results of numerical realization, we will provide a description of the model and theoretical base.

\section{Description of the model}

We will consider a model of transportation with an initial station of departure of cargo $i=0$, intermediate stations $i=1,2, \ldots, m$ and final station of distribution of cargo $i=m+1$. It is supposed that between two neighboring stations there is an interexchange railway track where part of cargo can temporarily be stored in special storage areas. We consider the capacity of such storage areas unlimited. The movement of cargo happens in one direction. On any intermediate station with number $i$ cargo can arrive as from the previous station with number $(i-1)$ and the storage area located between them. Similarly, from any intermediate station with number $i$ cargo can be sent or to the following station with number $(i+1)$ or on the storage area located between them. Work of all stations consists of receiving, processing and shipping cargo, and stations have a set capacity. Capacity is understood as the maximum volume of cargo which can pass through the intermediate station for a single interval of time. Processing of cargo happens in nodes of stations. At any time, the number of involved nodes at $n$-th station is denoted by $z_{n}(t)$. In each node during a unit of time, a single volume of cargo is processed. It is obvious that the quantity of the involved nodes for processing freight at trouble-free operation of the whole chain of transportation is limited. The maximum number of such nodes designated through $\Delta$ determines the capacity of stations.

The organization of similar freight traffic depends on technologies for receiving, processing and dispatch of freight. We will describe these technologies.

The first technology for intermediate stations is based on the established standard rules of interaction of the neighboring stations. For each station with number $i$ there are rules of interaction from previous $(i-1)$-th station and the subsequent $(i+1)$-th station. According to the rule of interaction with the previous station, the station with number $i$, depending on the quantity of the involved nodes on $(i-1)$-th station, has to increase or reduce the quantity of the involved nodes with a speed $\alpha\left(z_{i-1}-z_{i}\right)$ (i.e. to accept freight from the previous station if the quantity of the involved nodes on $(i-1)$-th station is more than on $i$-th station, or to send to a storage area if the quantity of the involved nodes on $(i-1)$-th station is less than on $i$-th station). According to the rule of interaction with the subsequent station, the station with number $i$, depending on the quantity of the involved nodes on $(i+1)$-th station, has to reduce or increase the quantity of the involved nodes with a speed $\alpha\left(z_{i}-z_{i+1}\right)$ (i.e. to send to the following station if the quantity of the involved nodes on $i$-th station is more than on $(i+1)$-th station, or to accept from a storage area if the quantity of the involved nodes on $i$-th station is less than on $(i+1)$-th station).

At the initial station $(i=0)$, the first technology is determined by means of the rule of interaction with the subsequent station and rules of handover of freight on it, determined by the function $\psi_{1}(t)$, depending on time variable $t \geq 0$. We assume that the function $\psi_{1}($.) is piecewise infinitely differentiable.

The first technology does not account for conditions of limited throughput capacity of stations. Furthermore, it does not allow us to use the full potential of stations. Therefore, along with the first technology, other technology is also used.

The second technology for intermediate stations allows us to increase the number of the involved nodes (if it does not exceed $\Delta$ ) or decrease them (if it exceeds $\Delta$ ). In this case, the freight is accepted from a storage area or goes to a storage area. It follows from determination of the second technology that the function setting the speed of change of the number of involved processing nodes within this technology has the following properties: on a half-line $(-\infty, 0]$ identically equal 0 , on an interval $\left(0, z_{\text {opt }}\right)$ is increasing, in a point $z_{\text {opt }}$ accepts the maximum value, on a half-line $\left(z_{\text {opt }},+\infty\right)$ is decreasing, in a point $\Delta$ accepts zero value, and on a half-line is linear. The schedule of this function is represented in Figure 1.

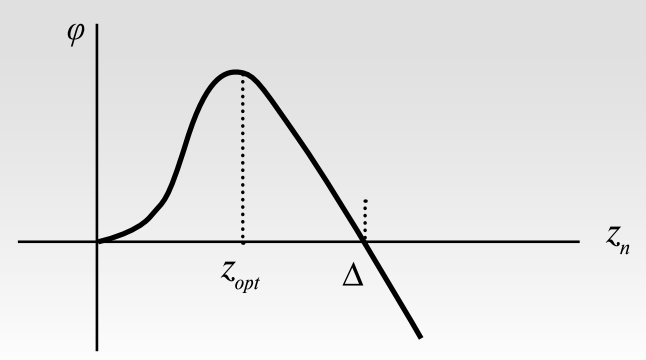

Fig. 1. Speed of change of the number of involved processing nodes at the intermediate station within the second technology 
We assume that function $\varphi($.$) is twice continuously dif-$ ferentiable, with regularly limited first and second derivatives. It is obvious that such a function and its derivative meet Lipschitz's condition with constants $L_{0}$ and $L_{1}$, respectively. We will designate $c=-\dot{\varphi}(\Delta)$. Parameter $c>0$ determines the intensity of sending freight from intermediate stations to storage areas.

For the initial station $(i=0)$, the second technology is used only for unloading. Therefore, the speed of change of the number of involved handling nodes at the initial station within the second technology is described by the function $\varphi_{0}($.$) , depending on the quantity of the involved$ nodes at the initial station which schedule is represented in Figure 2.

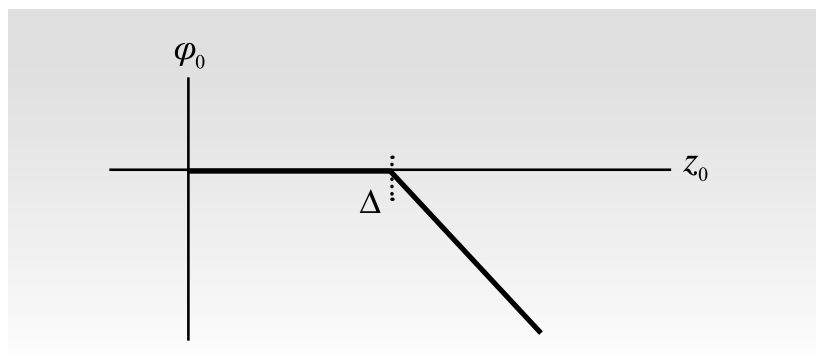

Fig. 2. Speed of change of the number of involved processing nodes at the initial station within the second technology

It is obvious that in case the amount of freight on 0 -th station is not exceeding $\Delta$, only the first technology is used. We will designate $c_{0}=-\dot{\varphi}_{0}(\Delta)$. Parameter $c_{0}>0$ determines the intensity of sending freight from the initial station to the storage area.

At the final station $(i=m+1)$, the first technology is determined by means of the rule of interaction with the previous station and the rule for apportionment of freight from it, described by function $\psi_{2}(t), t \geq 0$. We assume that function $\psi_{2}$ (.) is piecewise continuous. The second technology for a final station is the same as for intermediate stations.

For cargo transportation, it is necessary to have an efficient and simple control system. The amounts of the processed freight for any planned interval of time at all stations shall match a certain log of time, single for all stations. Such a condition can be described in the following way: there is a number $\tau>0$, which is not depending on $t$ and $i$, it that at $i=0,1,2, \ldots, m$ and $t \in[0,+\infty)$ equality is carried out:

$$
z_{i}(t)=z_{i+1}(t+\tau) .
$$

Thus, taking into account the work of the first and second technologies, and also the control systems, accept- ance and sending freight will be described by the following system of differential equations:

$$
\begin{gathered}
\dot{z}_{0}(t)=\psi_{1}(t)-\alpha z_{0}+\alpha z_{1}+\varphi_{0}\left(z_{0}\right), t \in[0,+\infty), \\
\dot{z}_{i}(t)=\alpha z_{i-1}-2 \alpha z_{i}+\alpha z_{i+1}+\varphi\left(z_{i}\right), \\
i=1,2, \ldots, m, t \in[0,+\infty) \\
\dot{z}_{m+1}(t)=\alpha z_{m}-\alpha z_{m+1}-\psi_{2}(t)+\varphi\left(z_{m+1}\right), t \in[0,+\infty), \\
z_{i}(t)=z_{i+1}(t+\tau), i=0,1,2, \ldots, m, t \in[0,+\infty) .
\end{gathered}
$$

The solution of the system of differential equations (6) - (8), satisfying the condition (9) is called a solution of traveling-wave type.

\section{Theoretical basis of research}

In works [8-10] the system (6) - (9) has been investigated. We will give substantial aspects of this research.

By means of replacement of time $t \rightarrow \tau t$ we will rewrite the system (6) - (9) in the form:

$$
\begin{gathered}
\dot{x}_{0}(t)=\tau\left[\bar{\psi}_{1}(t)-\alpha x_{0}+\alpha x_{1}+\varphi_{0}\left(x_{0}\right)\right], t \in[0,+\infty), \\
\dot{x}_{i}(t)=\tau\left[\alpha x_{i-1}-2 \alpha x_{i}+\alpha x_{i+1}+\varphi\left(x_{i}\right)\right], \\
i=1,2, \ldots, m, t \in[0,+\infty), \\
\dot{x}_{m+1}(t)=\tau\left[\alpha x_{m}-\alpha x_{m+1}-\bar{\psi}_{2}(t)+\varphi\left(x_{m+1}\right)\right], t \in[0,+\infty), \\
x_{i}(t)=x_{i+1}(t+1), \quad i=0,1,2, \ldots, m, t \in[0,+\infty)
\end{gathered}
$$

where

$$
\begin{gathered}
x_{i}(t)=z_{i}\left(\frac{t}{\tau}\right), \quad \bar{\psi}_{1}(t)=\psi_{1}\left(\frac{t}{\tau}\right), \quad \bar{\psi}_{2}(t)=\psi_{2}\left(\frac{t}{\tau}\right), \\
i=0,1,2, \ldots, m, m+1, \quad t \in[0,+\infty) .
\end{gathered}
$$

At the initial stage we considered narrowing of system $(10)-(13)$ on the segment $[0,1]$, i.e. system:

$$
\begin{gathered}
\dot{x}_{0}(t)=\tau\left[\bar{\psi}_{1}(t)-\alpha x_{0}+\alpha x_{1}+\varphi_{0}\left(x_{0}\right)\right], t \in[0,1] \\
\dot{x}_{i}(t)=\tau\left[\alpha x_{i-1}-2 \alpha x_{i}+\alpha x_{i+1}+\varphi\left(x_{i}\right)\right], \\
i=1,2, \ldots, m, t \in[0,1] \\
\dot{x}_{m+1}(t)=\tau\left[\alpha x_{m}-\alpha x_{m+1}-\bar{\psi}_{2}(t)+\varphi\left(x_{m+1}\right)\right], t \in[0,1] \\
x_{i}(0)=x_{i+1}(1), \quad i=0,1,2, \ldots, m .
\end{gathered}
$$

The theorem of existence and uniqueness of the solution of system (14) - (17) has been proven. According to the solution $\left\{\tilde{x}_{i}(.)\right\}_{i=0,1,2, \ldots, m+1}$ of system (14) - (17) func- 
tions $\overline{\psi_{1}}(),. \bar{\psi}_{2}($.$) and \left\{x_{i}(.)\right\}_{i=0,1,2, \ldots, m+1}$ on a half-line $[0,+\infty)$ have been constructed:

$$
\left\{\begin{array}{l}
x_{i}(t)=\tilde{x}_{i}(t), i=0,1,2, \ldots, m+1, t \in[0,1] ; \\
x_{i}(t)=x_{i-1}(t-1), i=1,2, \ldots, m+1, \\
t \in(k, k+1), k=1,2, \ldots ; \\
x_{0}(t)=x_{0}(t-1)+\frac{\overline{\psi_{1}}(t-1)}{\alpha}+\frac{\varphi_{0}\left(x_{0}(t-1)\right)-\varphi\left(x_{0}(t-1)\right)}{\alpha}, \\
t \in(k, k+1), \quad k=1,2, \ldots ; \\
\bar{\psi}_{1}(t)=\frac{1}{\alpha \tau} \dot{\overline{\psi_{1}}}(t-1)+\frac{1}{\alpha \tau}\left[\dot{\varphi}_{0}\left(x_{0}(t-1)\right)-\dot{\varphi}\left(x_{0}(t-1)\right)\right] \dot{x}_{0}(t-1)+ \\
+\frac{\dot{x}_{0}(t-1)}{\tau}+\bar{\psi}_{1}(t-1)+\varphi_{0}\left(x_{0}(t-1)\right)-\varphi\left(x_{0}(t-1)\right)- \\
-\varphi_{0}\left(x_{0}(t-1)+\frac{\bar{\psi}_{1}(t-1)}{\alpha}+\frac{\varphi_{0}\left(x_{0}(t-1)\right)-\varphi\left(x_{0}(t-1)\right)}{\alpha}\right), \\
t \in(k, k+1), \quad k=1,2, \ldots ; \\
\bar{\psi}_{2}(t)=\alpha x_{m}(t-1)-\alpha x_{m+1}(t-1), t \in(k, k+1), k=1,2, \ldots .
\end{array}\right.
$$

Definition 3. The quasi-solution of system (10)-(13) is called the set of piecewise strongly absolutely continuous functions $\left\{x_{i}(.)\right\}_{i=0,1,2, \ldots, m+1}$ with gaps only in points $k$ $=1,2, \ldots$ and almost everywhere satisfying to this system.

The lemma is proven according to which the solution of the boundary value problem (14) - (17), extended to the half $[0,+\infty)$ in the relations $(18)$, is the quasi-solution of system (10) - (13).

\section{Results of numerical experiments}

As was noted, this work is devoted to numerical implementation of the given model for organizing cargo transportation. We will give the results of research into the numerical solution of the system (10) - (13) describing this model. In numerical experiments, the number of stations was equal to 10: the initial station of positioning freight $(i=0)$, intermediate stations $(i=1,2, \ldots, 8)$ and final station of distribution of freight $(i=9)$. According to the results given in the previous paragraph, numerical implementation of system (10) - (13) consists of two stages. At the first stage, the solution of the system which is restriction of the initial system $(10)-(13)$ on the segment $[0,1]$, i.e. the solution of the following system is found:

$$
\begin{gathered}
\dot{x}_{0}(t)=\tau\left[\overline{\psi_{1}}(t)-\alpha x_{0}+\alpha x_{1}+\varphi_{0}\left(x_{0}\right)\right], t \in[0,1] \\
\dot{x}_{i}(t)=\tau\left[\alpha x_{i-1}-2 \alpha x_{i}+\alpha x_{i+1}+\varphi\left(x_{i}\right)\right], \\
i=1,2, \ldots, 8, t \in[0,1]
\end{gathered}
$$

$$
\begin{gathered}
\dot{x}_{9}(t)=\tau\left[\alpha x_{8}-\alpha x_{9}-\bar{\psi}_{2}(t)+\varphi\left(x_{9}\right)\right], t \in[0,1] \\
x_{i}(0)=x_{i+1}(1), \quad i=0,1,2, \ldots, 8 .
\end{gathered}
$$

Before passing to the numerical solution of this system, it is necessary to define functions $\varphi(),. \bar{\psi}_{1}(t), \bar{\psi}_{2}(t)$. Function $\varphi($.) on the segment $[0, \Delta]$ is set by means of a parabola $y=-a x^{2}+b x$, where $a>0, y(\Delta)=0$ (see Figure 1). Thus, coefficients of a parabola are connected by the ratio $b=a \Delta$. It is obvious that the greater is $a$, the greater the intensity of cargo received on the second technology. We will pass to the choice of functions $\bar{\psi}_{1}($.) and $\bar{\psi}_{2}($.). We remind the reader that these functions determine, respectively, intensity of shipping freight at the initial station and intensity of distribution of freight from the final station. It is obvious that the intensity of shipping freight at the initial station is subject to seasonality. Moreover, in order to avoid jams at stations, the cargo receiving period at the initial station shall be replaced by the period of more intensive freight shipment with initial to the following station. Similar reasoning is fair also for the final station (the distribution period of freight from a final station is replaced by the period of more intensive receiving of cargo from the previous station). Owing to the above, in quality $\bar{\psi}_{1}($.$) and \bar{\psi}_{2}($.$) periodic func-$ tions $\bar{\psi}_{1}(t)=\bar{\psi}_{2}(t)=\gamma \cos (\omega t)$ are used, while amplitude and the period of functions are model parameters. After definition of functions $\varphi(),. \bar{\psi}_{1}(t), \bar{\psi}_{2}(t)$ we proceed to the solution of the boundary value problem (19) - (22). The solution algorithm is as follows.

1. We find the solution of equations (19) - (21) with initial conditions

$$
x_{0}(0)=\Delta, x_{1}(0)=\Delta, \ldots, x_{9}(0)=\Delta .
$$

For the solution found $\left\{x_{i}(.)\right\}_{0}^{9}$ we calculate the following expression:

$Q=\left(x_{0}(0)-x_{1}(1)\right)^{2}+\left(x_{1}(0)-x_{2}(1)\right)^{2}+\ldots+\left(x_{8}(0)-x_{9}(1)\right)^{2}$.

2. For a previously set small value $\varepsilon>0$ by means of a gradient method, we find the solution of the system of differential equations (19) $-(21)$ with initial conditions for which the condition $Q<\varepsilon$ is satisfied. On each iteration of a gradient method, the solution of the system of equations (19) - (21) is found by means of the method of Runge-Kutta, fourth order. Thus, we receive the solution of the system (19) - (21) for which the condition (22) is satisfied with a certain accuracy. We will call such decisions solutions of the system (19) - (22). At the second stage, the solution of the boundary value problem $(19)-(22)$ continues in $(1,+\infty)$ accordance with the re- 
lations (18). As we know from the previous section, as a result we get the quasi-solution system (10) - (13), i.e. functions $x_{i}($.$) , satisfying this system and having gaps at$ the points $k=1,2, \ldots$.

The main purpose of the study - to determine the form and dynamics of the quasi-solution of the system (10) - (13) and also to study their dependence on model parameters $\alpha, a, \gamma, \omega, c_{0}, c$ and $\tau$. Note that all these parameters are positive. The results of the numerical experiments are presented in the following two propositions.

Proposition 1. Quasi-solutions of system (10) - (13) satisfy the following restriction

$$
\begin{gathered}
\Delta_{1}-e^{\beta_{1} t} \leq x_{i}(t) \leq \Delta_{2}+e^{\beta_{2} t}, i=0,1, \ldots 9, \text { where } \\
\Delta_{1}<\Delta+1, \Delta_{2}>\Delta-1, \beta_{1}>0, \beta_{2}>0 .
\end{gathered}
$$

Thus, according to proposition 1, quasi-solutions of the system (10) - (13) both from above, and from below are majorized by exponential functions. For example, the schedule of one of quasi-solutions of system (10) - (13) is provided on Figure 3.

This quasi-solution is received at $\Delta=10$ and the following values of parameters:

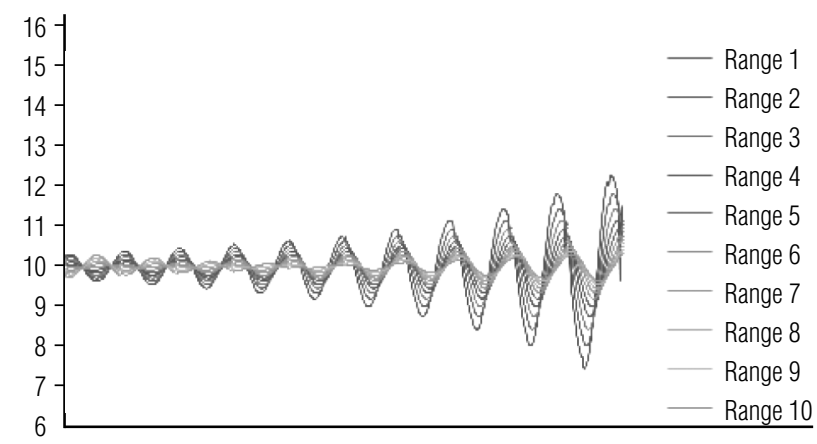

Range $1-x_{0}($.$) , Range 2-x_{1}(),. \ldots$, Range $10-x_{9}($.

Fig. 3. Quasi-solution schedule of the system of differential equations (basic case)

$$
\alpha=60, a=0.1, \gamma=5, \omega=2 \pi, c_{0}=0.1, c=0.1, \tau=1 .
$$

To see ruptures of functions on schedules, we will give a small fragment of Figure 3 (a segment [3.5; 5.5], gaps in points 4 and 5).

As can be seen from Figure 4, the biggest gap at these points has a function $x_{0}($.). Further, with increasing numbers coordinates quasi-solution breaks are reduced. This trend remains also in the subsequent integer points. For comparison, in Figure 5 we will provide histograms of ruptures of functions $x_{0}(),. x_{1}(),. x_{2}(),. x_{3}($.$) (histograms$ of other functions aren't provided to avoid encumbering the figure).

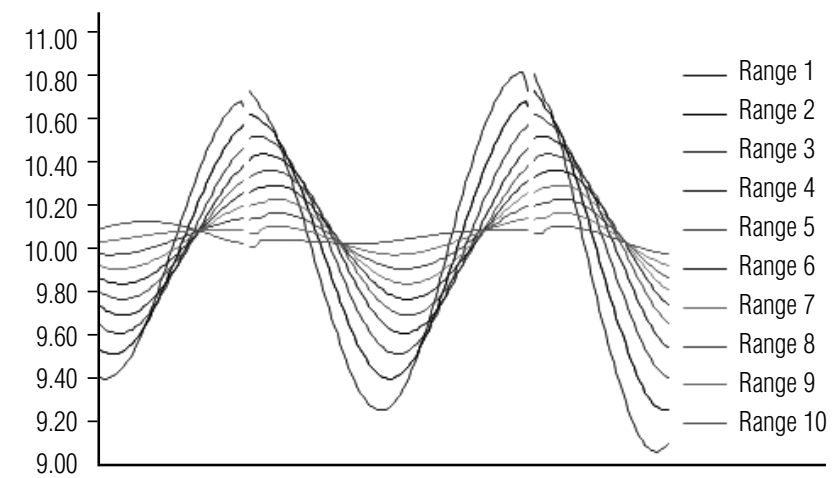

Range $1-x_{0}($.$) , Range 2-x_{1}(),. \ldots$, Range $10-x_{9}($.

Fig. 4. Fragment of the quasi-solution schedule of system of the differential equations (basic case)

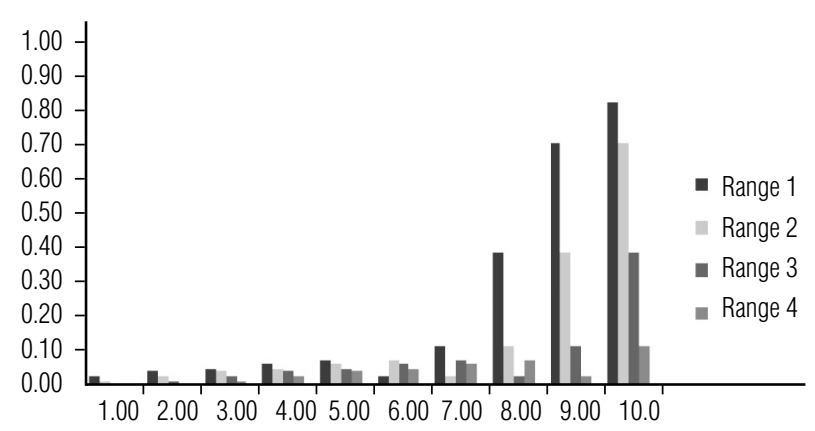

Range $1-x_{0}($.$) , Range 2-x_{1}($.$) ,$

Range $3-x_{2}($.$) , Range 4-x_{3}($.

Fig. 5. Histograms of gaps (basic case)

For these values of the parameters of inequality (23) takes the following form:

$$
10.75-e^{0.09 t} \leq x_{i}(t) \leq 9.25+e^{0.08 t}, \quad i=0,1, \ldots 9 .
$$

Parameters $\beta_{1}, \beta_{2}$ of the functions majorizing quasisolutions of the system (10) - (13) depend on the parameters of this system; therefore, we will designate them:

$$
\beta_{1}=\beta_{1}\left(\alpha, a, \gamma, \omega, c_{0}, c, \tau\right), \beta_{2}=\beta_{2}\left(\alpha, a, \gamma, \omega, c_{0}, c, \tau\right) .
$$

As a result of numerous experiments, it has been revealed that function $\beta_{1}($.$) is monotone in all parameters$ except for the parameter $c$ concerning which it is invariable. Function $\beta_{2}($.$) also is monotone in all parameters$ except for the parameter $a$, concerning which it is invariable. We will provide more detailed formulation of this result in the following proposition.

Proposition 2. Functions $\beta_{1}($.$) and \beta_{2}($.$) have the fol-$ lowing properties: 
1) $\frac{\partial \beta_{1}(.)}{\partial \alpha}<0, \frac{\partial \beta_{2}(.)}{\partial \alpha}<0 ; \quad$ 2) $\frac{\partial \beta_{1}(.)}{\partial a}>0, \frac{\partial \beta_{2}(.)}{\partial a}=0 ;$

3) $\frac{\partial \beta_{1}(.)}{\partial \gamma}>0, \frac{\partial \beta_{2}(.)}{\partial \gamma}>0$; 4) $\frac{\partial \beta_{1}(.)}{\partial \omega}>0, \frac{\partial \beta_{2}(.)}{\partial \omega}>0$;

5) $\frac{\partial \beta_{1}(.)}{\partial c_{0}}>0, \frac{\partial \beta_{2}(.)}{\partial c_{0}}<0 ; \quad$ 6) $\frac{\partial \beta_{1}(.)}{\partial c}=0, \frac{\partial \beta_{2}(.)}{\partial c}>0$,

7) $\frac{\partial \beta_{1}(.)}{\partial \tau}<0, \frac{\partial \beta_{2}(.)}{\partial \tau}<0$.

We will give below schedules of quasi-solutions of system $(10)-(13)$ in which alternately value of one of parameters differs from the value given in (24) at invariable values of other parameters. At the same time value $\Delta$ is also invariable and equal to 10 . Besides, for these quasisolutions we will receive estimate (23).

The schedule of the quasi-solution of system (10) (13) with the following values of parameters is shown on Figure 6:

$$
\alpha=85, a=0.1, \gamma=5, \omega=2 \pi, c_{0}=0.1, c=0.1, \tau=1 .
$$

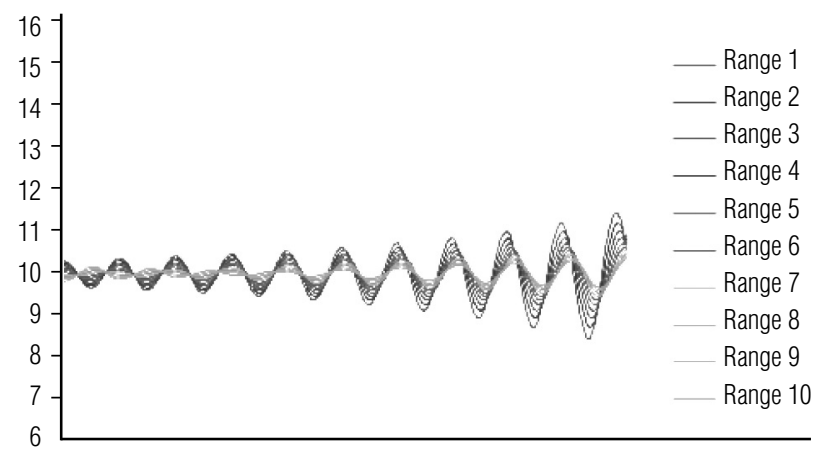

Range $1-x_{0}($.$) , Range 2-x_{1}(),. \ldots$, Range $10-x_{9}($.

Fig. 6. Quasi-solution schedule of the system of differential equations with the increased value of parameter $\alpha$

We will notice that in comparison with (24), value $\alpha$ is increased. For these values of the parameters, inequality (23) takes the following form:

$$
10.86-e^{0.07 t} \leq x_{i}(t) \leq 9.29+e^{0.06 t}, i=0,1, \ldots 9 .
$$

The schedule of the quasi-solution of system (10) (13) with the following values of parameters is shown on Figure 7:

$$
\alpha=60, a=0.4, \gamma=5, \omega=2 \pi, c_{0}=0.1, c=0.1, \tau=1 .
$$

In comparison with (24), value $a$ is increased. For these values of the parameters inequality (23) takes the following form:

$$
10.88-e^{0.12 t} \leq x_{i}(t) \leq 9.39+e^{0.08 t}, i=0,1, \ldots 9 .
$$

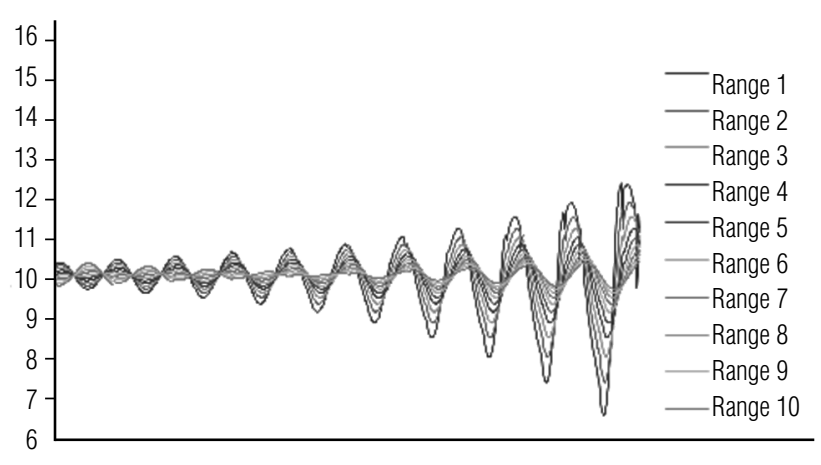

Range $1-x_{0}($.$) , Range 2-x_{1}(),. \ldots$, Range $10-x_{9}($.

Fig. 7. Quasi-solution schedule of system of the differential equations with the increased value of parameter $a$

The schedule of the quasi-solution of system (10) (13) with the following values of parameters is shown on Figure 8:

$$
\alpha=60, a=0.1, \gamma=10, \omega=2 \pi, c_{0}=0.1, c=0.1, \tau=1 .
$$

In comparison with (24), value $\gamma$ is increased. For these values of the parameters, inequality (23) takes the following form:

$$
10.61-e^{0.15 t} \leq x_{i}(t) \leq 9.63+e^{0.13 t}, i=0,1, \ldots 9 .
$$

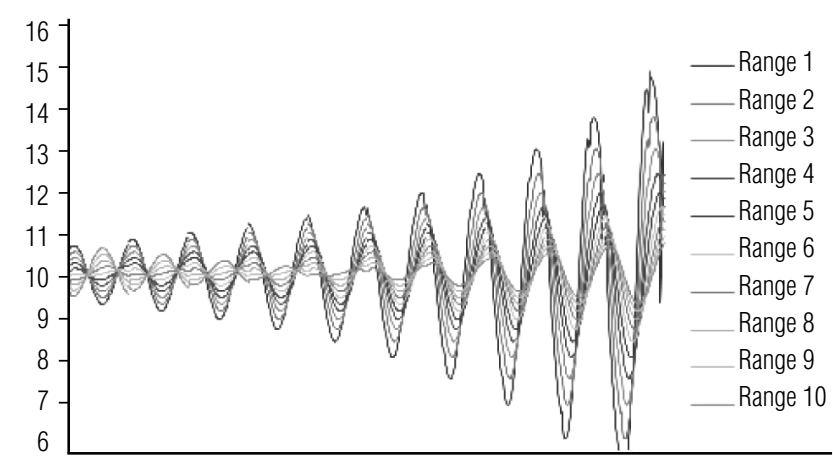

Range $1-x_{0}($.$) , Range 2-x_{1}(),. \ldots$, Range $10-x_{9}($.

Fig. 8. Quasi-solution schedule of the system of differential equations with the increased value of parameter $\gamma$

The schedule of the quasi-solution of system (10) (13) with the following values of parameters is shown on Figure 9:

$$
\alpha=60, a=0.1, \gamma=5, \omega=4 \pi, c_{0}=0.1, c=0.1, \tau=1 .
$$

In comparison with (24), value $\omega$ is increased. For these values of the parameters, inequality (23) takes the following form:

$$
10.86-e^{0.12 t} \leq x_{i}(t) \leq 9.2+e^{0.1 t}, i=0,1, \ldots 9 .
$$




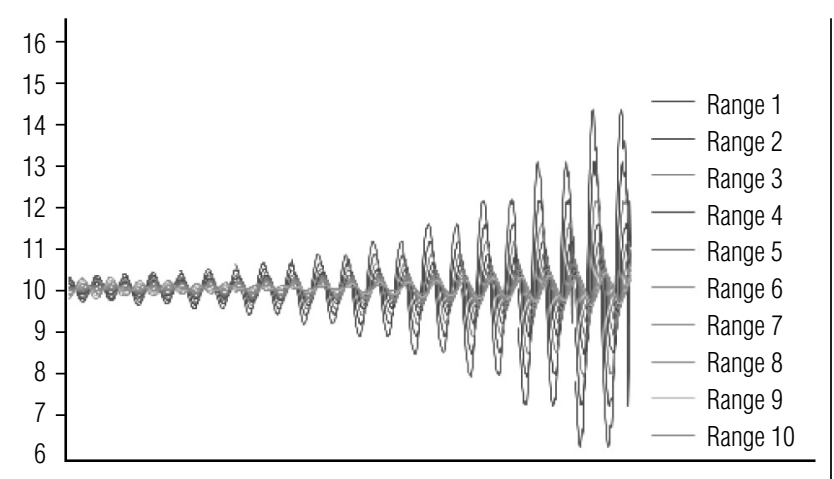

Range $1-x_{0}($.$) , Range 2-x_{1}(),. \ldots$, Range $10-x_{9}($.

Fig. 9. Quasi-solution schedule of the system of differential equations with the increased value of parameter $\omega$

The schedule of the quasi-solution of system (10) (13) with the following values of parameters is shown on Figure 10:

$$
\alpha=60, a=0.1, \gamma=5, \omega=2 \pi, c_{0}=2, c=0.1, \tau=1 .
$$

In comparison with (24), value $c_{0}$ is increased. For these values of the parameters, inequality (23) takes the following form:

$$
10.92-e^{0.11 t} \leq x_{i}(t) \leq 9.26+e^{0.07 t}, i=0,1, \ldots 9 .
$$

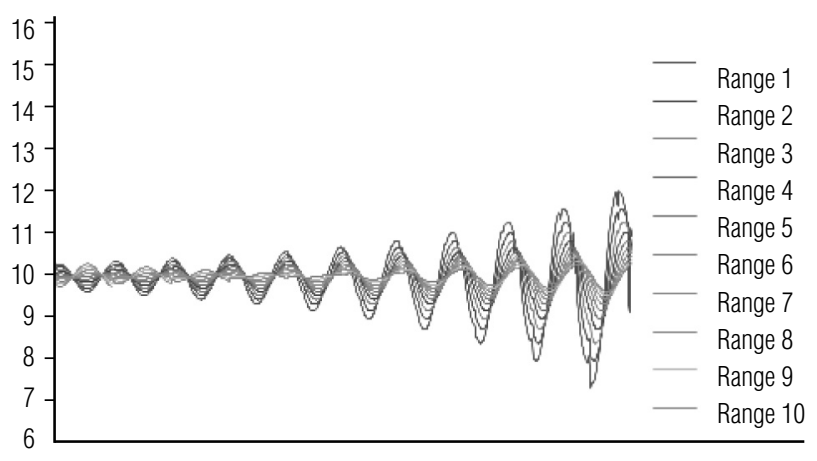

Range $1-x_{0}($.$) , Range 2-x_{1}(),. \ldots$, Range $10-x_{9}($.

Fig. 10. Quasi-solution schedule of the system of differential equations with the increased value of parameter $c_{0}$

The schedule of the quasi-solution of system (10) (13) with the following values of parameters is shown on Figure 11:

$$
\alpha=60, a=0.1, \gamma=5, \omega=2 \pi, c_{0}=0.1, c=2, \tau=1 .
$$

In comparison with (24), value $c$ is increased. For these values of the parameters, inequality (23) takes the following form:

$$
10.72-e^{0.09 t} \leq x_{i}(t) \leq 9.2+e^{0.1 t}, i=0,1, \ldots 9 .
$$

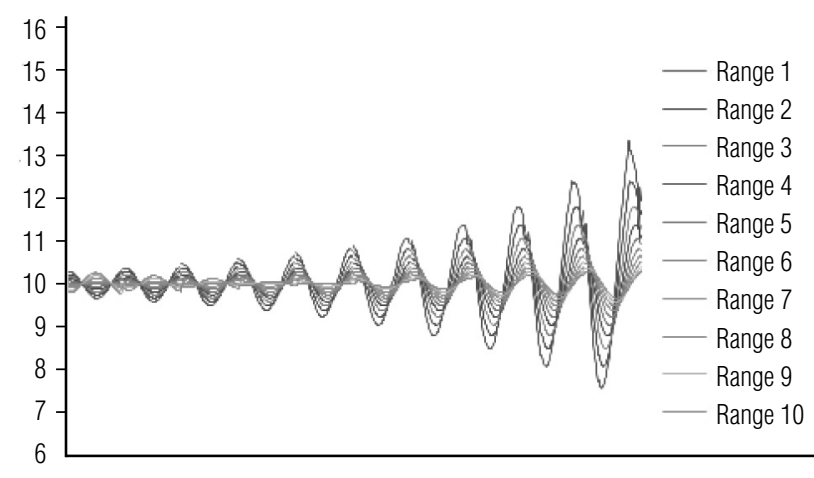

Range $1-x_{0}($.$) , Range 2-x_{1}(),. \ldots$, Range $10-x_{9}($.

Fig. 11. Quasi-solution schedule of the system of differential equations with the increased value of parameter $c$

Lastly, the schedule of the quasi-solution of the system (10) - (13) with the following values of parameters is shown on Figure 12:

$$
\alpha=60, \gamma=5, \omega=2 \pi, a=0.1, c_{0}=0.1, c=0.1, \tau=4 .
$$

In comparison with (24), value $\tau$ is increased. For these values of the parameters, inequality (23) takes the following form:

$$
10.79-e^{0.04 t} \leq x_{i}(t) \leq 9.42+e^{0.03 t}, i=0,1, \ldots 9 .
$$

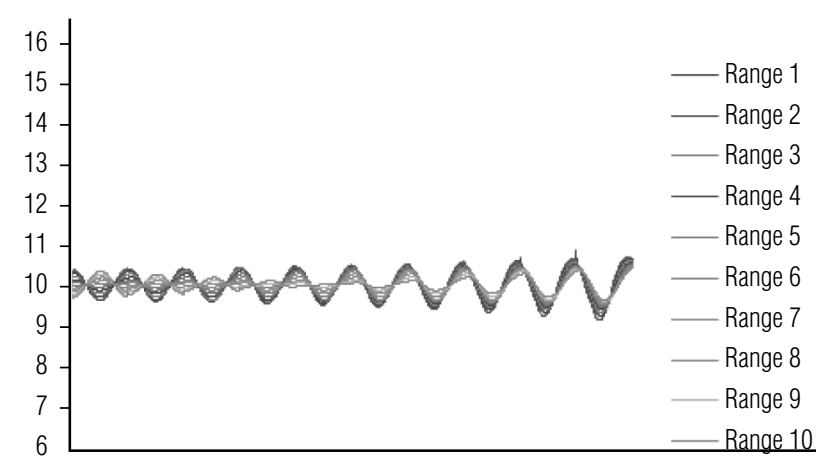

Range $1-x_{0}($.$) , Range 2-x_{1}(),. \ldots$, Range $10-x_{9}($.

Fig. 12. Quasi-solution schedule of the system of differential equations with the increased value of parameter $\tau$

In conclusion, we will pass to the analysis of results of the following from proposition 2 and having practical value. It follows from proposition 2 that growth of quasi-solutions of the system (10) - (13) decreases with an increase of parameters $\alpha$ and $\tau$, and also with reduction of parameters $\gamma$ and $\omega$. Numerical experiments have shown that similarly conduct to themselves and ruptures of quasi-solutions of the system (10) - (13), i.e. they decrease with an increase of parameters $\alpha$ and $\tau$ and reduction of parameters $\gamma$ and $\omega$. For example, for comparison 
with Figure 5, we will provide histograms of ruptures of functions $x_{0}(),. x_{1}(),. x_{2}(),. x_{3}($.$) , which are components$ of quasi-solutions of the system (10) - (13) with the increased value of parameter $\alpha$ (with 60 to 85 ) and at invariable values of other parameters (Figure 13).

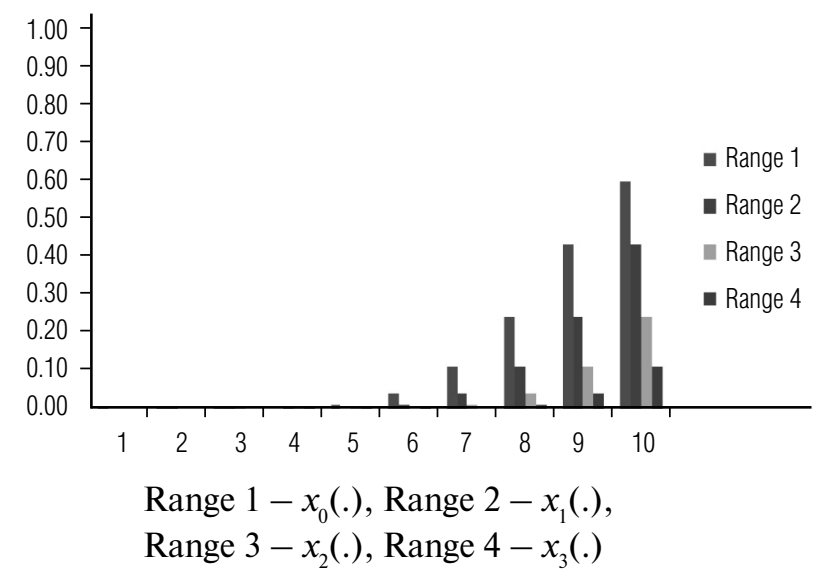

Fig. 13. Histograms of gaps with an increased value of parameter $\alpha$

We remind the reader that parameters $\gamma$ and $\omega$ are characteristics of intensity of shipping freight on the initial station and cannot be operated by the organizer of cargo transportation unlike parameters $\alpha$ and $\tau$. Thus, the organizer of cargo transportation can effectively reduce the load of stations, increasing intensity of the movement of freight traffic (parameter $\alpha$ ) and the characteristic of the control system (parameter $\tau$ ). However, here it must be kept in mind that for great values $\tau$ the control system loses relevance. Thus, the choice of parameter $\alpha$ depends only on the technical capabilities of the infrastructure of cargo transportation, and the choice of parameter $\tau$ has to be reached at the expense of a compromise between technical capabilities of the infrastructure of cargo transportation and the relevance of the control system.

\section{Conclusion}

This article is devoted to numerical realization of a model for organizing cargo transportation between two node stations with a set rule of control. Such a model is described by a finite-dimensional system of differential equations with nonlocal linear restrictions (the rule of control). The class of the solution satisfying nonlocal linear restrictions is extremely narrow. It results in the need for the "correct" extension of solutions of the system of differential equations to a class of quasi-solutions. Based on the theoretical basis presented in [8-10], it was possible numerically using the Runge-Kutta method to build these quasi-solutions and determine their rate of growth. Furthermore, dependence of the quasi-solutions and, in particular, the sizes of gaps (jumps) on solutions from a number of the parameters of the model characterizing a rule of control, and technologies for transportation of cargo and intensity of shipping cargo on a node station has been researched.

\section{References}

1. Galaburda V.G. (1983) Sovershenstvovanie tekhnologii perevozok $i$ uvelichenie propusknoy sposobnosti zheleznykh dorog [Improvement of transportation techniques and increase in railroad traffic capacity]. Moscow: Moscow State University of Railway Engineering (in Russian).

2. Galaburda V.G. (1985) Optimal'noe planirovanie gruzopotokov [Optimal planning of cargo traffic]. Moscow: Transport (in Russian).

3. Kozovskii I.G. (1977) Ratsionalizatsiya perevozok gruzov na zheleznykh dorogakh [Improvement of railroad goods transportation]. Moscow: Transport (in Russian).

4. Levin D.Yu. (2010) Modelirovanie protsessov perevozki [Modeling of transportation processes]. World of Transport and Transportation, vol. 8, no. 5 (33), pp. 48-55 (in Russian).

5. Rubtsov A.O, Tarasov A.S. (2009) Modelirovanie zheleznodorozhnykh perevozok na territorii Rossii [Modeling of railway transport in the territory of Russia]. Proceedings of the Institute of System Analysis of Russian Academy of Sciences, no. 46, pp. 274-278 (in Russian).

6. de Jong G., Gunn H.F., Walker W. (2004) National and international freight transport models: an overview and ideas for further development. Transport Reviews, vol. 24, no. 1, pp. 103-124.

7. Yamada T., Russ B.F., Castro J., Taniguchi E. (2009) Designing multimodal freight transport networks: A heuristic approach and applications. Transportation Science, vol. 43, no. 2, pp. 129-143.

8. Beklaryan L.A., Khachatryan N.K. (2013) Ob odnom klasse dinamicheskikh modeley gruzoperevozok [On one class of dynamic transportation models]. Computational Mathematics and Mathematical Physics, vol. 53, no. 10, pp. 1649-1667 (in Russian).

9. Beklaryan L.A., Khachatryan N.K. (2006) Traveling wave type solutions in dynamic transport models. Functional Differential Equations, vol. 13, no. 2, pp. 125-155.

10. Akopov A.S., Khachatryan N.K. (2014) Sistemnaya dinamika: uchebno-metodicheskoe posobie [System dynamics: Educational-methodical manual]. Moscow: CEMI RAS (in Russian). 


\section{Модель организации грузоперевозок с начальной станцией отправления и конечной станцией распределения грузов²}

\section{Н.К. Хачатрян}

кандидат физико-математических наук

старший научный сотрудник лаборатории динамических моделей экономики и оптимизации

Центральный экономико-математический институт, Российская академия наук; доцент кафедры бизнес-аналитики

Национальный исследовательский университет «Высшая школа экономики»

Адрес: 117418, г. Москва, Нахимовский проспект, д. 47

E-mail:nerses@cemi.rssi.ru; nkhachatryan@hse.ru

\section{А.C. Акопов}

доктор технических наук, профессор кафедры бизнес-аналитики

Национальный исследовательский университет «Высшая школа экономики»

Адрес: 101000, г. Москва, ул. Мясницкая, д. 20

E-mail:aakopov@hse.ru

\section{Аннотация}

В статье рассматривается модель организации грузоперевозок между двумя узловыми станциями, соединенными железнодорожной линией, которая содержит определенное количество промежуточных станций. Движение грузопотока осуществляется в одном направлении. Такая ситуация может иметь место, например, в случае, если одна из узловых станций расположена в регионе добычи сырья для предприятия, находящегося в другом регионе и располагающего другой узловой станцией. Организация грузопотока осуществляется с помощью ряда технологий. Эти технологии определяют правило подачи грузов на начальную узловую станцию, правила взаимодействия соседних станций, а также правило распределения грузов с конечной узловой станции. Процесс грузоперевозок сопровождается заданным правилом контроля. Для такой модели требуется определить возможные режимы грузоперевозок и описать их свойства.

Данная модель описывается конечномерной системой дифференциальных уравнений с нелокальными линейными ограничениями. Класс решений, удовлетворяющих нелокальным линейным ограничениям, оказывается чрезвычайно узким. Это приводит к необходимости «правильного» расширения решений системы дифференциальных уравнений до класса квазирешений, отличительной особенностью которых является наличие разрывов в счетном числе точек. С помощью метода РунгеКутта четвертого порядка удалось численно построить указанные квазирешения и определить скорость их роста. Отметим, что в техническом плане основная сложность заключалась именно в получении квазирешений, удовлетворяющих нелокальным ограничениям. Кроме того, исследована зависимость квазирешений и, в частности, величин разрывов (скачков) решений от ряда параметров модели, характеризующих правило контроля, технологии перевозки грузов и интенсивность подачи грузов на узловую станцию.

Ключевые слова: организация грузоперевозок, динамическая модель, дифференциальные уравнения, решения типа бегущей волны, численная реализация.

Цитирование: Khachatryan N.K., Akopov A.S. Model for organizing cargo transportation with an initial station of departure and a final station of cargo distribution // Business Informatics. No. 1 (39). P. 25-35. DOI: 10.17323/1998-0663.2017.1.25.35.

Работа выполнена при поддержке Российского фонда фундаментальных исследований (проект № 16-01-00110) 


\section{Литература}

1. Галабурда В.Г. Совершенствование технологии перевозок и увеличение пропускной способности железных дорог. М.: МИИТ, 1983.

2. Галабурда В.Г. Оптимальное планирование грузопотоков. М.: Транспорт, 1985.

3. Козовский И.Г. Рационализация перевозок грузов на железных дорогах. М.: Транспорт, 1977.

4. Левин Д.Ю. Моделирование процессов перевозки // Мир транспорта. 2010. Т. 8. № 5 (33). С. $48-55$.

5. Рубцов А.О., Тарасов А.С. Моделирование железнодорожных перевозок на территории России // Труды Института системного анализа Российской академии наук. 2009. № 46. С. 274-278.

6. de Jong G., Gunn H.F., Walker W. National and international freight transport models: an overview and ideas for further development // Transport Reviews. 2004. Vol. 24. No. 1. P. 103-124.

7. Designing multimodal freight transport networks: A heuristic approach and applications / T. Yamada [et al.] // Transportation Science. 2009. Vol. 43. No. 2. P. 129-143.

8. Бекларян Л.А. Хачатрян Н.К. Об одном классе динамических моделей грузоперевозок // Журнал вычислительной математики и математической физики. 2013. Т. 53. № 10. С. 1649-1667.

9. Beklaryan L.A., Khachatryan N.K. Traveling wave type solutions in dynamic transport models // Functional Differential Equations. 2006. Vol. 13. No. 2. P. 125-155.

10. Акопов А.С., Хачатрян Н.К. Системная динамика: учебно-методическое пособие. М.: ЦЭМИ РАН, 2014. 


\title{
Development of requirements for a decision support system aimed at quality assessment of public services provided based on the ontological approach ${ }^{1}$
}

\author{
Liliya R. Chernyakhovskaya \\ Professor, Department of Technical Cybernetics \\ Ufa State Aviation Technical University \\ Address: 12, Karl Marx Street, Ufa, Republic of Bashkortostan, 450008, Russian Federation \\ E-mail: Irchern@yandex.ru
}

\author{
Albina F. Galiullina \\ Doctoral Student, Department of Technical Cybernetics \\ Ufa State Aviation Technical University \\ Address: 12, Karl Marx Street, Ufa, Republic of Bashkortostan, 450008, Russian Federation \\ E-mail: GAF1205@yandex.ru
}

\begin{abstract}
This article describes the requirements for a decision support system which is designed to assess the quality of public services. Requirements for a decision support system are used as a starting point at its design stage and determine the functions of the developed system without showing the mechanism of its implementation. At the same time, the requirements serve as constraints in the process of system development. The set of the developed requirements for the decision support system includes basic, functional, non-functional and economic requirements.

We propose to use the ontological approach in the development of requirements for the system. This allows us to solve a number of problems arising from the description of the requirements in natural language: the lack of exposition clarity, misrepresentation of the requirements and so on. The ontological model allows developers to interpret the requirements in the same way, to structure the specification of requirements for the system and to eliminate blurring in their definitions. Ontological representation of knowledge about requirements for the developed system and about the system providing public services in general is used for the semantic integration of existing information resources, appropriate interpretation of the content of text documents and search queries presented in a natural language. The developed ontology improves the quality of user (stakeholder) interaction during the system operation. In addition, it includes rules for term combination to provide reliable assertions on the state of the decision support system.
\end{abstract}

Key words: decision support system, system of providing public services, basic requirements, functional requirements, non-functional requirements, economic requirements, quality assessment of public services provided, ontological model for decision support.

Citation: Chernyakhovskaya L.R., Galiullina A.F. (2017) Development of requirements for a decision support system aimed at quality assessment of public services provided based on the ontological approach.

Business Informatics, no. 1 (39), pp. 36-47. DOI: 10.17323/1998-0663.2017.1.36.47.

\footnotetext{
${ }^{1}$ This work was supported by the Russian Foundation for Basic Research, project no. 14-08-97023 "Intellectual support of managing decision-making in innovative projects relying on knowledge processing and mathematical modeling"
} 


\section{Introduction}

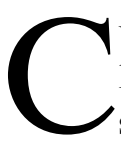
urrently in the Russian Federation issues related to the quality of services provided by the state have particular relevance and social significance. Organizations providing public services represent a queuing system that serves for the interaction of the country's population with state authorities, and this system should guarantee the maximum satisfaction of the citizens' needs in public services. At the same time, in accordance with one of the main directions of the realization of the Information Society Development Strategy in the Russian Federation approved by the President of the Russian Federation on 7 February 2008, it is necessary to improve the quality and responsiveness of the public services provided, including through e-government and the transfer of public services to electronic form. By the Decree of the President of the Russian Federation dated 7 May 2012 No. 601 "About the main directions for improving the system of public administration" it was determined that by 2018 the Russian Federation citizens' satisfaction level with the quality of public and municipal services provided should be at least $90 \%$.

Despite the relevance of solving the problem of improving the quality of public services, there is still no single methodology for their comprehensive assessment. There are various methods given in this article which are based on various indicators and criteria to assess the quality of public services. To date, a systematic approach to the analysis and quality assessment of the services is needed. The process of assessing provision of public services requires decision support in problem situations based on application of scientific approaches, namely, knowledge engineering and the ontological approach.

\section{Existing methods for assessing the quality of public services}

The works of such researchers as A. Parasuraman, V.A. Zeithaml, L.L. Berry, L. Gaster, G. Van Ryzin, S.I. Nedelko, A.V. Ostashkov, N.S. Mirzoyan, S.S. Tsukar, A.N. Lunev, N.B. Pugacheva, M.V. Koptev and others are devoted to assessment of service quality, including public services.

A. Parashuraman, V.A. Zeithaml and L.L. Berry proposed a method of assessing the quality of services SERVQUAL (abbreviated from "SERVice QUALity"), which involves measuring the service quality using a quantitative indicator - the service quality index SQI $[1,2]$. The service quality index SQI shows the ratio of the perceived and expected service quality. The SQI cal- culation is based on the results of the questioning service consumers. To measure customer expectations and perception of the quality of services received, two basic questionnaires are used. These include 22 pairs of questions grouped according to indicators of reliability, credibility, responsiveness, tangibility, sympathy. Questionnaires allow respondents to answer the questions using the seven-point Likert scale: from "absolutely disagree" to "absolutely agree". Note that the main problem of the results obtained through SERVQUAL questionnaires, and in particular the key indicator - the general quality index SQI - is the low degree of its informativeness. The index value itself can signal only the conformity of the assessed service to the quality or low quality category. The general index SQI rather reflects the average value, that is, a low score on one of the determinants can be compensated by a high score for another, while the general value SQI will be satisfactory. Thus, the development of specific recommendations requires a detailed analysis of the values of individual determinants, as well as the corresponding quality indices.

The SERVQUAL method was applied in the field of public services in the works of L. Gaster and G. Van Ryzin [3, 4]. The results of L. Gaster's study [3] showed that the lower social layers more often claim that they are satisfied with public services, while the more affluent often complain about the poor quality of public services. Social workers usually have higher expectations from social services, and therefore they think more critically and skeptically about the quality of services provided. As a result of the analysis of public satisfaction in the public services sector by G. Van Ryzin [5], it was revealed that respondents show a low degree of satisfaction with public sector services. The researcher explains this by the fact that the assessment of the public services' quality is based on public judgments about satisfaction with the authorities' activities.

To assess the public services, two groups of criteria are proposed by S.I. Nedelko and A.V. Ostashkov [6]:

1) the criteria for assessing the convenience (availability) of receiving the service: the consumer's awareness about receiving the service, the convenience of waiting for the service, the convenience of receiving the service, the availability of the service provided, the attitude of the staff to the consumer of the service, the possibility of appealing against actions by the personnel;

2) criteria for assessing the quality of the final result of the service: the time spent on receiving the final result of the service (quick response), the content quality of the final result of the service, staff competence. 
In addition to these two groups of criteria N.S. Mirzoyan [7] offers a third group - the amount of resources spent by the consumer to receive the service.

These criteria can be used as indicators for calculating the indices of satisfaction with the public services provided.

S.S. Tsukar [8] noted that in the development of services providing the public services, priorities are gradually shifting from traditional formats of providing services to modern electronic forms of interaction between government and society within the framework of the e-government concept. Together with the change of priorities, the structure of the criteria for quality assessment of the services provided is also changing. So, if in the traditional way that services are received by citizens the physical convenience of receiving services and personnel were important for them, then organizational barriers, problems of information perception and readiness for the use of new technologies play an important role in the electronic format of interaction. Therefore, the issues of assessing the quality of how public services are provided need to be approached differentially, taking into account the change in the weights of certain assessment criteria, i.e. the changed structure of quality criteria for providing the services in electronic form.

A.N. Lunev and N.B. Pugacheva [9] used the following basic criteria to assess the quality and availability of public services:

1) the level of public services quality characterized by the timeliness and speed of the services provided, compliance with the service standard, administrative regulations and service consumer requests $(\mathrm{Q} 1)$;

2) the level of public services availability, taking into account the convenience of waiting for and receiving the services, simplicity and rationality, contact and efficiency, openness and transparency $(\mathrm{Q} 2)$;

3 ) the level of consumer confidence in government authorities and their agencies providing public services (Q3).

The assessment of the quality and availability of public services is based on the value of the complex indicator $\mathrm{Q}=\mathrm{Q} 1+\mathrm{Q} 2+\mathrm{Q}$.

M.V. Koptev [10] noted that public service quality is characterized by the quality of the agency's internal processes and is ensured by the accurate operation of the operational accounting unit, the so-called "back office":

clear implementation of the administrative regulations of providing public services and compliance with legal norms and standards requirements;

$\checkmark$ qualified performance by public servants of their official regulations;

$\checkmark$ completeness, integrity, relevance and reliability of the information resources used;

using modern information and telecommunication technologies.

Assessment of the public services quality, according to M.V. Koptev, should be carried out directly by the applicants by an initiative order in specially developed questionnaires. It can be filed in multifunctional centers (MFCs), agencies providing services or on their websites, as well as through a public services portal where there is the possibility of filing a response. In addition, a project on public services assessment by means of sms messages has been launched and is being implemented.

As a result of the surveys conducted, a database is being formed analyzing the client experience of those who received the services. This base should form the basis for improving the entire system of providing public services in general and improve the work of the federal agency employees who provide public services, in particular.

However, despite all the changes made and available methods of quality assessment, the monitoring and assessment system of the public services quality is not fully debugged and needs to be improved.

\section{The need for decision support in assessment of the quality of public services}

State authorities, including federal agencies providing public services, like any modern organizational systems, operate in difficult conditions. Their viability depends on the ability to adapt their behavior to current and future environmental changes. Organizations need to mobilize information resources and apply knowledge engineering to ensure effective management of business processes, in particular, the process of providing public services and assessing the quality of this process. The problems of knowledge management in organizations are considered in the studies of many scientists [11-13].

Examples of corporate knowledge creation can be found in large Japanese, American, European companies such as Canon, Honda, Matsushita, Boeing, IBM, British Petroleum, etc., applying a holistic approach to knowledge management and adaptive behavior of the organization, as well as implementation of innovative projects based on new knowledge and ideas. 
In the management process, it is necessary to ensure compatibility of the concepts used, models and methods of knowledge management based on their formalization in order to improve the quality and quick response of management decisions. The following knowledge classes are defined in the organization: intuitive, implicit knowledge (heuristics, intuition, experience, skills), formalized, conceptual knowledge (mathematical models, rules for organizing effective actions), background, context knowledge (knowledge defining the cognitive context of activity conceptualization) [14]. Explicit knowledge is usually formalized in accordance with the accepted model of knowledge representation, for example, in the form of product rules and other formal models regulating processes management. Implicit knowledge for intellectual decision support is presented in the form of precedents of problem situations [15].

At present, the development of ontologies is proceeding actively, representing a clear conceptualization of subject areas and ensuring the interaction of the organization's specialists in solving complex problems in a single information space. Despite the development of the ontological analysis theory, as well as the development and application of new tools for creating ontologies, the integration problems of ontology and knowledge management remain insufficiently researched.

In order to ensure the required quality of the public services provided, it is necessary to conduct their assessment on an ongoing basis and make timely proper (correct) management decisions. To do this, it is necessary to apply scientific approaches (knowledge engineering) to decision support in problem situations arising when assessing the quality of providing public service. Decision support is a set of procedures that provides the decisionmaker with the necessary information and recommendations that facilitate the decision-making process.

Using the knowledge and experience of the organization, which are concentrated in standards, methods, administrative regulations and software applications, as source material for building a decision support system (DSS) will improve management efficiency and create the necessary information environment for the exchange of views and experience between specialists participating in the process of assessing the quality of public services.

Decision support systems are a relevant and developing field of information systems application for organizations [16].

The decision support system development for quality assessment of how public services are provided is implemented in accordance with the requirements submitted by various owners to the developed system at different stages of its life cycle. When requirements are forming, some contradictions may arise. Their reasons may be the different. In particular, such reasons include:

$\diamond$ different visions of consumer properties of DSS by various management subjects [17];

different assessments of problematic situations by various management subjects [18];

$\diamond$ the state of uncertainty of the external environment with regard to the control object $[19,20]$ and the internal environment of the control object [20,21], as well as a unique combination of internal and external environments [22];

$\diamond$ rejection by stakeholders of past commitments and unilateral violation of the agreements reached [20, 23].

The identification of contradictions at the early development stage is a critical success factor of the complex system management. Timely detection of contradictions and finding ways to resolve them prevent the appearance of difficulties. This makes it possible eventually to reduce the cost of DSS creation for assessing the quality of how public services are provided.

In addition, when DSS is being created, the experts often have complex problems, the cause of which is not always clear. In particular, it is difficult to describe the activities performed by the developed system clearly.

In connection with the above, authors offer to describe the functionality and limitations are imposed on the developed system, that is, requirements for DSS, complete and clearly.

As shown by many studies, mistakes made at the stage of gathering requirements constitute $40-50 \%$ of all defects found in the developed system $[24,25]$. The main causes of DSS development project failure are incorrect information from users and disadvantages of defining and managing user requirements [26].

Development of the requirements will make it possible to avoid more serious errors and problems at later stages of the DSS development for assessing the quality of how public services are provided.

\section{Requirements for a decision support system}

Development of the requirements for the DSS is a process involving activities that necessitate creating and approving the document stipulating the system requirements [27].

There are four main stages of the requirements development process for the DSS: 
1) feasibility study of the DSS development from a technical point of view;

2) formation and analysis of requirements for the DSS;

3) specifying requirements for the DSS;

4) relevant documentation development and certification of requirements for the DSS.

The chart of requirements for a decision support system developed by the authors is shown in Figure 1 .

The set of requirements for the DSS includes basic requirements, functional and non-functional requirements and economic requirements.

Basic requirements include the basic purpose of the developed decision support system and present highlevel generalized requirements. The DSS is being developed to form recommendations for decision-making, document decision-making, to ensure interaction between decision-makers and other stakeholders in the decision-making process, and to register the assessment of the decision support quality by the decision-maker or an expert.

Functional requirements cover expected behavior of DSS defining the actions that the system is able to perform. These requirements include decision support in the process of providing public services, registration of inconsistencies in quality of how public services are provided, description and analysis of the problem situation arising in assessing the quality of how public services are provided, search for solutions using rules and precedents of decision-making, ontological analysis, logging of citizens requests, the development and application of the knowledge base (KB), the development and regular updating of normative legal documentation database, event logging, etc.

Non-functional requirements are not directly related to the functions performed by the system. These requirements do not define the behavioral aspects of the system in the process of providing public services. They are associated with such integration properties of the system as the protection of confidential data, reliability, accuracy, communication, work in real time, access to the database and knowledge base, etc.

In particular, we note such non-functional requirement as speedy response. Responsiveness indicators are obtained using the decision support system as a queuing system (QS). QS has such indicators as the absolute, relative and nominal throughput, the number of QS channels, the idle factor and others.

Also it should be noted that many non-functional requirements apply to DSS on the whole and not to its in- dividual assets. Some non-functional requirements are more critical than individual functional requirements. If an error is made in the functional requirement, this can lead to a decrease in the quality of the developed system. If the error is made in non-functional requirements, for example, in the requirements of fault tolerance or controllability, then this can make the system completely inoperable.

Economic requirements imply an economic aspect is taken into account in the DSS development in the process of providing public services. It is necessary to assess the possible risks, the economic efficiency, the DSS realization cost and the time spent for realization and implementation of the DSS.

The system for providing public services must ensure conformity of the automated process of providing services to the requirements of normative legal acts including administrative regulations determining the order of providing public services by the executive bodies of state authority, federal agencies, local authorities and others.

\section{Application of the ontological approach to solving communication problems in the development of requirements for a decision support system}

In the class of decision support systems, intelligent decision support systems (IDSS) are allocated that are designed to help decision-makers manage complex objects and processes of various nature in the face of tight time constraints and the presence of uncertainty of various kinds (incompleteness, fuzziness and inconsistency of the original information, etc.). Such systems belong to the class of integrated intellectual systems that combine rigorous mathematical methods and solution search models with nonstrict, heuristic (logic-linguistic) models and methods based on the knowledge of experts, models of human reasoning and accumulated experience [28]. A distinctive feature of the tasks solved with the help of intelligent DSS is the impossibility of obtaining all the objective information necessary for decisionmaking, and in this connection - the use of subjective expert, poorly structured information. Highly qualified specialists of government bodies, federal agencies, state institutions, as well as experts engaged in scientific research in the field of knowledge management can be involved as experts.

The central component of IDSS is its knowledge base. The knowledge base is a set of information about the subject area organized in accordance with the accepted knowledge representation model. The knowledge base contains information relevant to a particular subject 


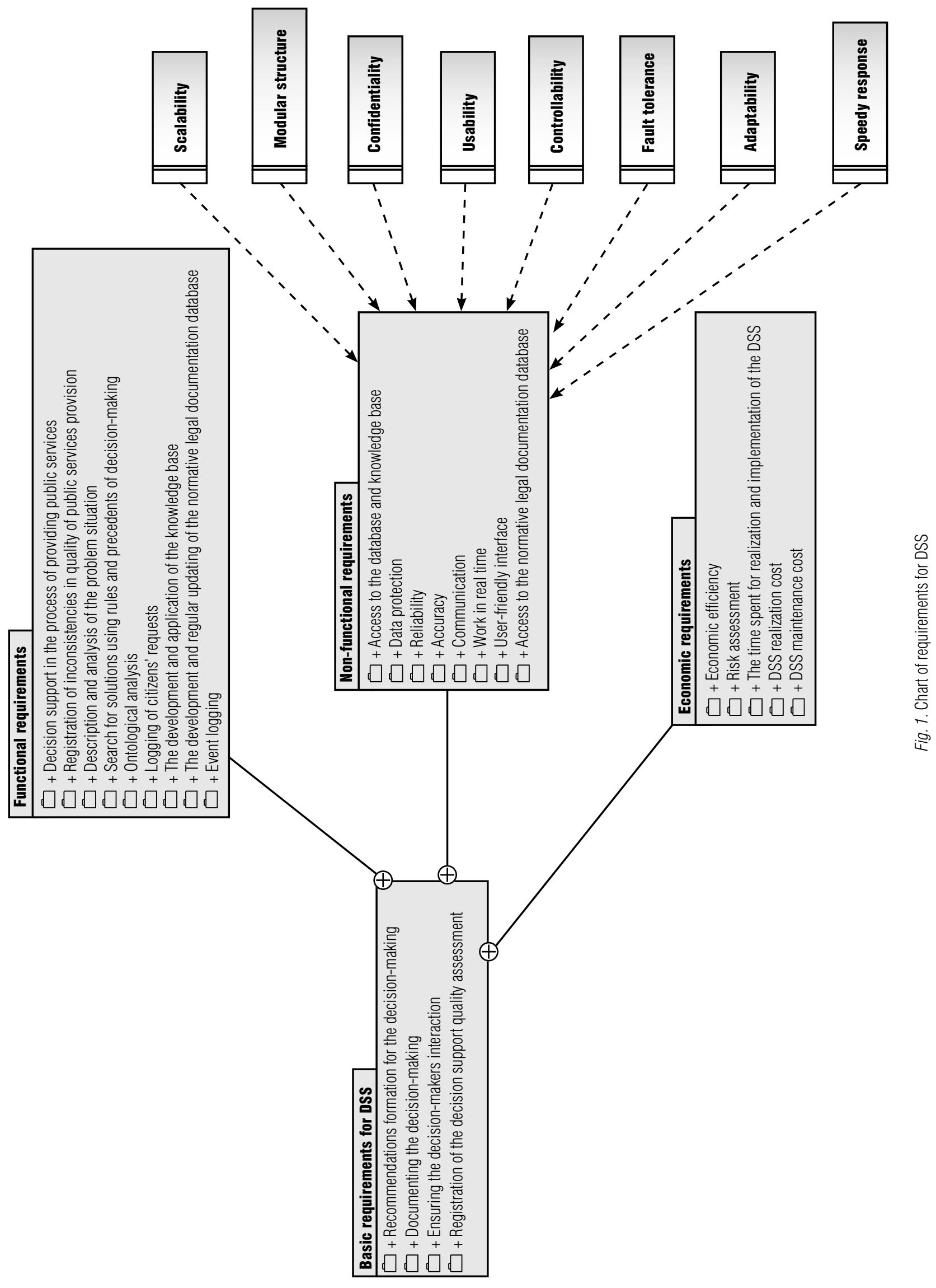


area: rules describing relationships and phenomena, individual facts, and also, possibly, methods, heuristic algorithms and various ideas related to decision-making in the relevant subject area [29].

One of the most important tasks in the development of DSS is the task of obtaining knowledge from a subject area expert and presenting it in the knowledge base of the IDSS.

The formalism of the knowledge description is called the knowledge representation model. There are various models of knowledge representation: ontology, logical model, product model, semantic network, frame model, precedents, dynamic model, etc.

Ontology is the explicit specification of conceptualization [30]. Formally, the ontology consists of terms organized in the taxonomy, their definitions and attributes, as well as the axioms associated with them and the rules of inference. In other words, ontology is knowledge formally presented on the basis of conceptualization, which involves the description of a multitude of objects and concepts, knowledge about them and the connections between them.

Ontology enhances the intelligence of knowledge management systems based on a representation of what often remains implicit or uncertain. Ontology solves the problem of sharing and reusing knowledge by various users and / or computer programs [31].

In each subject area, experts have their own specific scientific vocabulary (there is no single terminology). Some terms are used in several disciplines with similar but not identical meanings; there are synonyms, antonyms, homonyms. Therefore, it is extremely urgent to solve the problem of representing natural language information in a machine-interpreted form [32].

There is a need to develop a unified, detailed and consistent terminology that can be used in various formal contexts and applications. Ontology is a convenient way to create such terminology, taking into account the context of the subject area. Ontology takes into account the paradigmatic relations of concepts that are not dependent on the context of the problem solution, and the rules for the formation of syntagmatic relations concept variables arising in a certain context of the problem solution [33].

The approach based on ontologies is flexible enough and universal and has a number of advantages that justify its use in an environment with large volumes of information and the need to quickly extract its parts. As such, an environment is the decision support environment for assessment of the public services quality. This environment provides: collection of theoretical knowledge, its representation in the form of a semantic network of concepts and relations between concepts;

$\downarrow$ increasing the effectiveness of information searching based on the structuring and classification of stored knowledge;

$\checkmark$ the ability to collect, accumulate, process and present knowledge in the organization's Intranet network in accordance with the concept of "semantic web" [29].

When developing DSS, an approach is proposed based on the definition of requirements groups: functional, non-functional, economic, etc.

Some problems are arising during the requirements development due to the fact that there is no clear understanding of the differences between different levels of requirements. Requirements are commonly used as a means of communication between the different stakeholders. This means that the requirements should be simple and understandable for ordinary users of the decision support system and its developers, designers and others. In order to solve the problems arising, it is necessary clearly to distinguish the requirements of different levels and to determine the interpretation of the term of one requirement or another.

Specifications of DSS requirements are written in natural language and this often leads to certain problems when the detailed specification is written. The use of natural language implies that the same words and expressions in the requirements formulation are understood in the same way by stakeholders. However, in fact, this is not the case, since natural language has a certain blurring of concepts. As a consequence, the same requirement formulated by different specialists can be interpreted in different ways.

To avoid these problems and for unambiguous interpretation of the terms of the subject area (and, accordingly, the requirements for DSS developed for assessing quality of how public services are provided), we propose to develop the ontological model. This ontological model allows us to solve the problem of communication, structure requirements specification for DSS and eliminate blur of definitions. Thus, an approach is proposed to for intellectual decision support for assessment of the quality of how public services are provided based on the ontological knowledge base.

Using the ontological approach allows us to carry out an ontological analysis of the public services provision system and enables us to formulate the requirements for DSS designed to assess the effectiveness of how public services are provided. 


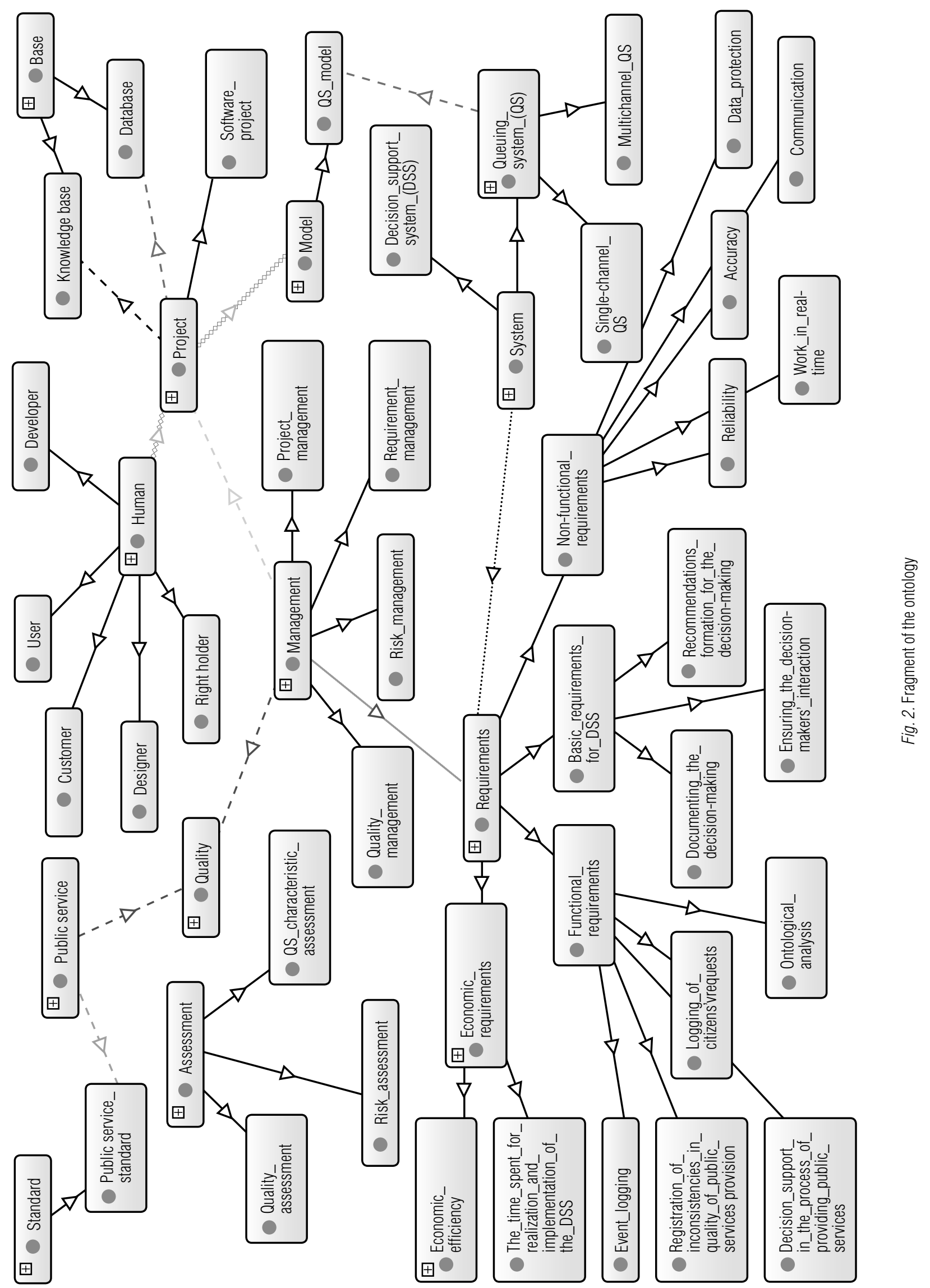


The advantage of using the ontological model is that it allows us to develop a metadata model. This greatly improves the interaction of a wide range of DSS users. Ontology enables us to provide the collective use of an understanding of the information structure by experts, state institutions employees, to re-use knowledge of the subject area as well as to analyze this knowledge.

The general concepts of the subject area, queuing systems and project management of DSS creation (based on a dictionary of software projects [34]) are included in the developed ontology as classes. Also, the developed ontology includes a hierarchy of requirements for DSS. Moreover, each term in the ontology has a straightforward interpretation. A fragment of the developed ontology is shown in Figure 2.

The developed ontology can be formally represented as [15]:

Onto $=<C, R, \operatorname{Pr}, V, I, A, D>$,

where $C$ - a set of classes $\left\{C_{1}, C_{2}, \ldots, C_{n}\right\}$;

$R$ - a set of relations $\left\{R_{1}, R_{2}, \ldots, R_{n}\right\}$;

$\mathrm{Pr}$ - properties of classes;

$V$ - values of properties: there is a division of properties into two classes in OWL: the object properties (instances of the class owl: ObjectProperty) and the properties of the data types (instances of the class owl: DatatypeProperty);

$I$ - a set of class instances $\left\{I_{1}, I_{2}, \ldots, I_{n}\right\}$ is determined by axioms and definitions of specific class properties;

$A$ - a set of axioms $\left\{A_{1}, A_{2}, \ldots, A_{n}\right\}$;

$D$ - a set of output algorithms at ontology $\left\{D_{1}, D_{2}, \ldots\right.$, $\left.D_{n}\right\}$

To find the necessary information in the developed ontology, a special request can be implemented by a specialist or other interested person. Through a request, any specialist involved in the development of a DSS for assessing the quality of public services provided (or another interested person) can find all the necessary information about the requirements for DSS by means of the developed ontology: find out which groups of requirements are relevant to DSS, and details of these requirements. Since the ontology contains the terms of the subject area, DSS users can form their requests for the developed ontology.

In addition to the terms, the ontology includes the rules according to which these terms can be combined to construct credible allegations about the state of the system at some moment in time. In addition, it may make appropriate conclusions based on these statements. These conclusions allow us to make changes in the system of how public services are provided to improve the quality.

\section{Conclusion}

The requirements development process for a decision support system to assess the quality of how public services are provided is very complicated and important, since errors in the requirements can lead to high costs for the development of the whole system.

A chart of the requirements for the DSS developed by the authors to assess the quality of how public services are provided is presented in this article. In addition, in this article they present an ontological model facilitating the interaction of the various stakeholders (users, developers and others) and allowing us to structure the specification of the requirements for the system.

\section{References}

1. Parasuraman A., Zeithaml V.A., Berry L.L. (1988) SERVQUAL: A multiple-item scale for measuring consumer perceptions of service quality. Journal of Retailing, vol. 64, no. 1, pp. 12-40.

2. Zeithaml V.A., Berry L.L., Parasuraman A. (1988) Communication and control processes in the delivery of service quality. Journal of Marketing, vol. 52, no. 2, pp. 35-48.

3. Gaster L., Squire A. (2003) Providing quality in the public sector: A practical approach to improving public services. Maidenhead, UK: Open University Press.

4. Van Ryzin G.G. (2004) The measurement of overall citizen satisfaction. Public Performance and Management Review, no. 273, pp. 9-28.

5. Van Ryzin G.G., Muzzio D., Immerwahr S., Gulick L., Martinez E. (2004) Drivers and consequences of citizen satisfaction: An application of the American customer satisfaction index model to New York City. Public Administration Review, vol. 64, no. 3, pp. $286-296$.

6. Nedelko S.I., Ostashkov A.V. (2008) Monitoring gosudarstvennykh i munitsipal'nykh uslug v regione kak strategicheskiy instrument povysheniya kachestva regional'nogo upravleniya: opyt, problemy, rekomendatsii [Monitoring of public and municipal services in the region as a strategic tool to improve the quality of regional governance: experience, problems, recommendations]. Moscow: Exlibris-Press (in Russian).

7. Mirzoyan N.S. (2010) Otsenka kachestva predostavleniya gosudarstvennykh (munitsipal'nykh) uslug [Quality assessment of public (municipal) services providing]. Tidings of the Tula State University. Economic and Legal Sciences, no. 2-2, pp. $217-223$ (in Russian).

8. Zucar S.S. (2014) Osobennosti otsenki kachestva predostavleniya gosudarstvennykh uslug v elektronnoy forme [Peculiarities of evaluation of quality of rendering state services in electronic form]. Management Consulting, no. 10 (70), pp. 137-144 (in Russian). 
9. Lunev A.N., Pugacheva N.B. (2013) Nauchno-metodicheskie rekomendatsii po otsenke kachestva i dostupnosti gosudarstvennykh i munitsipal'nykh uslug [Scientific and methodical recommendations on the assessment of the quality and accessibility of public and municipal services]. Society: Politics, Economics, Law, no. 4, pp. 15-27 (in Russian).

10. Koptev M.V. (2014) Otsenka kachestva predostavleniya gosudarstvennykh uslug v elektronnom vide [Estimating quality of public services provided in electronic form]. Problems of Modern Science and Education, no. 7, pp. 117-119 (in Russian).

11. Nonaka I. (1991) The knowledge-creating company. Harvard Business Review, vol. 69, no. 6, pp. 96-104.

12. Choo C.W., Auster E. (1993) Scanning the business environment: Acquisition and use of information by managers. Annual Review of Information Science and Technology, M.E. Williams (ed.). Medford, NJ: Learned Information, pp. 279-314.

13. Gavrilova T.A., Muromtsev D.I. (2008) Intellektual'nye tekhnologii v menedzhmente [Intellectual technologies in management]. St. Petersburg: Higher School of Management, St. Petersburg University (in Russian).

14. Vagin V.N., Pospelov D.A., eds. (2008) Dostovernyy i pravdopodobnyy vyvod v intellektual'nykh sistemakh [Reliable and plausible inference in intelligent systems]. Moscow: FIZMATLIT (in Russian).

15. Chernyakhovskaya L.R. (2010) Podderzhka prinyatiya resheniy pri strategicheskom upravlenii predpriyatiem na osnove inzhenerii znaniy [Decision support in strategic enterprise management based on knowledge engineering]. Ufa: ANRB, Gilem (in Russian).

16. Vostrov G.N., Mezhuev V.I. (2008) Problemy postroeniya informatsionnykh sistem nad predmetnymi oblastyami [Problems of construction of information systems on subject areas]. Artificial Intelligence, no. 4, pp. 736-746 (in Russian).

17. CIO (2011) Uchebnik 4CIO. Versiya 1.0 [Tutorial 4CIO. Version 1.0]. Moscow: 4CIO (in Russian).

18. Vittikh V.A. (2010) Organizatsiya slozhnykh system [Organization of complex systems]. Samara: Samara Scientific Center RAN (in Russian).

19. Lipaev V.V. (2005) Analiz i sokrashchenie riskov proektov slozhnykh programmnykh sredstv [Analysis and reduction of projects risks of complex software facilities]. Moscow: SINTEG (in Russian).

20. Rzevski G. (2014) Managing complexity. Proceedings of the 16th International Conference on Problems of Control and Modeling in Complex Systems, Samara, 30 June - 03 July 2014. pp. 3-12.

21. McConnel S. (2007) Skol'ko stoit programmnyy proekt [How much is the cost of a software project]. St. Petersburg: Piter (in Russian).

22. Gvozdev V.E., Ilyasov B.G. (2011) Piramida programmnogo proekta [Software project pyramid]. Software Engineering, no. 1, pp. 16-24 (in Russian).

23. Jordan E. (2008) Put'kamikadze [The path of the kamikaze]. Moscow: Lory (in Russian).

24. Davis A.M. (1993) Software requirements: Objects, functions, and states. Englewood Cliffs, NJ: Prentice Hall PTR.

25. Davis A.M. (1995) 201 principles of software development. NY: McGraw-Hill.

26. Wiegers K.E. (2004) Razrabotka trebovaniy k programmnomu obespecheniyu [Development of software requirements]. Moscow: Russian Edition (in Russian).

27. Klevtsov S.I. (2007) Analiz i formirovanie trebovaniy k PO informatsionnykh sistem sbora i obrabotki dannykh [Analysis and formation of requirements for information systems of data collection and processing]. Taganrog: TTI SFEDU (in Russian).

28. Korneev V.V., Gareev A.F., Vasyutin S.V., Raikh V.V. (2001) Bazy dannykh. Intellektualnaya obrabotka informacii [Database. Data mining]. Moscow: Knowledge (in Russian).

29. Paklin N.B., Oreshkov V.I. (2010) Biznes-analitika: ot dannykh $k$ znaniyam [Business intelligence: from data to knowledge]. St. Petersburg: Piter (in Russian).

30. Gruber T.R. (1993) A translation approach to portable ontology specifications. Knowledge Acquisition, no. 5 (2), pp. $199-220$.

31. Shkundina R.A. (2005) Organizatsiya podderzhki prinyatiya resheniy na osnove pretsedentov s pomoshch'yu ontologii predmetnoy oblasti [Organization of decision-making support on the basis of precedents with the help of domain ontology]. Proceedings of 3rd Conference on Artificial Intelligence in the XXI Century. Penza, pp. 70-72 (in Russian).

32. Filippovich Yu.N., Prokhorov A.V. (2002) Semantika informatsionnykh tekhnologiy: Opyty slovarno-tezaurusnogo opisaniya [Semantics of information technologies: Experience of dictionary and thesaurus description]. Moscow: MGUP (in Russian).

33. Smirnov S.V. (2001) Ontologicheskiy analiz predmetnykh oblastey modelirovaniya [Ontological analysis of modeling subject areas]. Tidings of Samara Scientific Center of RAS, vol. 3, no. 1, pp. 62-70 (in Russian).

34. Gvozdev V.E., Bezhaeva O.Ya., Tanzaly G.I., Efremova O.I. (2011) Programmnye proekty: bazovye terminy i opredeleniya [Software projects: basic terms and definitions]. Ufa: USATU (in Russian). 


\section{Разработка требований к системе поддержки принятия решений для оценки качества предоставления государственных услуг с применением онтологического подхода ${ }^{2}$}

\section{Л.Р. Черняховская}

доктор технических наук, профессор кафедры технической кибернетики Уфимский государственный авиационный технический университет Адрес: 450008, Республика Башкортостан, г. Уфа, ул. К. Маркса, д. 12 E-mail:Irchern@yandex.ru

\section{А.Ф. Галиуллина}

аспирант кафедры технической кибернетики

Уфимский государственный авиационный технический университет

Адрес: 450008, Республика Башкортостан, г. Уфа, ул. К. Маркса, д. 12

E-mail: GAF1205@yandex.ru

\section{Аннотация}

В статье представлено описание требований к системе поддержки принятия решений, которая предназначена для оценки качества предоставления государственных услуг. Требования к системе поддержки принятия решений используются в качестве отправной точки на этапе ее проектирования и определяют, что должна делать разрабатываемая система, не показывая при этом механизма ее реализации. Требования также служат ограничениями в процессе разработки системы. Совокупность разработанных требований к системе поддержки принятия решений включает основные, функциональные, нефункциональные и экономические требования.

Предлагается применение онтологического подхода при разработке требований к системе. Это позволяет решить ряд проблем, возникающих при описании требований на естественном языке: отсутствия четкости изложения, смешения требований, объединения требований и др. Разработанная онтологическая модель позволяет однозначно толковать требования к системе поддержки принятия решений для оценки качества предоставления государственных услуг, структурировать спецификацию требований к системе и исключить размытость их определений. Онтологическое представление знаний о требованиях к разрабатываемой системе и о системе предоставления государственных услуг в целом используется для семантической интеграции имеющихся информационных ресурсов, а также для адекватной интерпретации содержания текстовых документов и поисковых запросов, которые представлены на естественном языке. Разработанная онтология улучшает понимание и использование системы всеми заинтересованными лицами с точки зрения организации их взаимодействия. Разработанная онтологическая модель также включает правила, согласно которым термины скомбинированы для построения достоверных утверждений о системе поддержки принятия решений.

Ключевые слова: система поддержки принятия решений, система предоставления государственных услуг, основные требования, функциональные требования, нефункциональные требования, экономические требования, оценка качества предоставления государственных услуг, онтологическая модель поддержки принятия решений.

Цитирование: Chernyakhovskaya L.R., Galiullina A.F. Development of requirements for a decision support system aimed at quality assessment of public services provided based on the ontological approach // Business Informatics. 2017. No. 1 (39). P. 36-47. DOI: 10.17323/1998-0663.2017.1.36.47.

\footnotetext{
2 Работа выполнена при поддержке Российского фонда фундаментальных исследований, проект № 14-08-97023 «Интеллектуальная поддержка принятия решений при управлении инновационными проектами на основе обработки знаний и математического моделирования»
} 


\section{Литература}

1. Parasuraman A., Zeithaml V.A., Berry L.L. SERVQUAL: A multiple-item scale for measuring consumer perceptions of service quality // Journal of Retailing. 1988. Vol. 64. No. 1. P. 12-40.

2. Zeithaml V.A., Berry L.L., Parasuraman A. Communication and control processes in the delivery of service quality // Journal of Marketing. 1988. Vol. 52. No. 2. P. 35-48.

3. Gaster L., Squire A. Providing quality in the public sector: A practical approach to improving public services. Maidenhead, UK: Open University Press, 2003.

4. Van Ryzin G.G. The measurement of overall citizen satisfaction // Public Performance and Management Review. 2004. No. 273. P. 9-28.

5. Drivers and consequences of citizen satisfaction: An application of the American customer satisfaction index model to New York City / G.G. Van Ryzin [et al.] // Public Administration Review. 2004. Vol. 64. No. 3. P. 286-296.

6. Неделько С.И., Осташков А.В. Мониторинг государственных и муниципальных услуг в регионе как стратегический инструмент повышения качества регионального управления: опыт, проблемы, рекомендации. М.: Экслибрис-Пресс, 2008.

7. Мирзоян Н.С. Оценка качества предоставления государственных (муниципальных) услуг // Известия Тульского государственного университета. Экономические и юридические науки. 2010. № 2-2. С. 217-223.

8. Цукарь С.С. Особенности оценки качества предоставления государственных услуг в электронной форме // Управленческое консультирование. 2014. № 10 (70). С. 137-144.

9. Лунев А.Н., Пугачева Н.Б. Научно-методические рекомендации по оценке качества и доступности государственных и муниципальных услуг // Общество: политика, экономика, право. 2013. № 4. С. 15-27.

10. Коптев М.В. Оценка качества предоставления государственных услуг в электронном виде // Проблемы современной науки и образования. 2014. № 7. С. 117-119.

11. Nonaka I. The knowledge-creating company // Harvard Business Review. 1991. Vol. 69. No. 6. P. 96-104.

12. Choo C.W., Auster E. Scanning the business environment: Acquisition and use of information by managers // Annual Review of Information Science and Technology / M.E. Williams (Ed.). Medford, NJ: Learned Information, 1993. P. 279-314.

13. Гаврилова Т.А., Муромцев Д.И. Интеллектуальные технологии в менеджменте. СПб: Высшая школа менеджмента, СПбГУ, 2008.

14. Достоверный и правдоподобный вывод в интеллектуальных системах / Под ред. В.Н. Вагина, Д.А. Поспелова. М.: ФИЗМАТЛИТ, 2008.

15. Черняховская Л.Р. Поддержка принятия решений при стратегическом управлении предприятием на основе инженерии знаний. Уфа: АНРБ, Гилем, 2010

16. Востров Г.Н., Межуев В.И. Проблемы построения информационных систем над предметными областями // Искусственный интеллект. 2008. № 4. С. 736-746.

17. Учебник 4СІО. Версия 1.0. М.: 4СІО, 2011.

18. Виттих В.А. Организация сложных систем. Самара: Самарский научный центр РАН, 2010.

19. Липаев В.В. Анализ и сокращение рисков проектов сложных программных средств. М.: СИНТЕГ, 2004.

20. Rzevski G. Managing complexity // Труды XVI Международной конференции «Проблемы управления и моделирования в сложных системах». Самара, 30 июня - 03 июля 2014 г. С. 3-12.

21. Макконнел С. Сколько стоит программный проект. СПб: Питер, 2007.

22. Гвоздев В.Е., Ильясов Б.Г. Пирамида программного проекта // Программная инженерия. 2011. № 1. С. 16-24.

23. Йордон Э. Путь камикадзе. М.: Лори, 2008.

24. Davis A.M. Software requirements: Objects, functions, and states. Englewood Cliffs, NJ: Prentice Hall PTR, 1993.

25. Davis A.M. 201 principles of software development. NY: McGraw-Hill, 1995.

26. Вигерс К.И. Разработка требований к программному обеспечению / Пер. с англ. М: Русская редакция, 2004.

27. Клевцов С.И. Анализ и формирование требований к ПО информационных систем сбора и обработки данных. Таганрог: ТТИ ЮФУ, 2007.

28. Базы данных. Интеллектуальная обработка информации / В.В. Корнеев и [др.]. М.: Нолидж, 2001.

29. Паклин Н.Б., Орешков В.И. Бизнес-аналитика: от данных к знаниям. СПб: Питер, 2010.

30. Gruber T.R. A translation approach to portable ontology specifications // Knowledge Acquisition. 1993. No. 5 (2). P. $199-220$.

31. Шкундина P.A. Организация поддержки принятия решений на основе прецедентов с помощью онтологии предметной области // Сб. трудов III Всероссийской научно-технической конференции «Искусственный интеллект в XXI веке». Пенза, 2005. C. 70-72.

32. Филиппович Ю.Н., Прохоров А.В. Семантика информационных технологий: Опыты словарно-тезаурусного описания. М.: МГУП, 2002.

33. Смирнов С.В. Онтологический анализ предметных областей моделирования // Известия Самарского научного центра РАН. 2001. T. 3. № 1. C. $62-70$.

34. Программные проекты: базовые термины и определения / В.Е. Гвоздев и [др.]. Уфа: УГАТУ, 2011. 


\title{
A segment tree based Top-k RMQ algorithm and its application to the autocomplete problem
}

\author{
Mikhail S. Dvoretckii \\ MSc Program Student \\ Lomonosov Moscow State University; \\ Programmer, IQ Systems LLC \\ Address: 1, Leninskie Gory, Moscow, 119991, Russian Federation \\ E-mail: mike.dvorecky@gmail.com
}

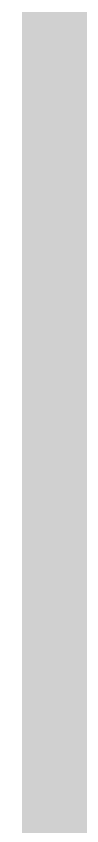

\begin{abstract}
An important way of ensuring data quality is controlling data input. One of the methods of doing that is checking the input data against the corresponding reference data where applicable. This may be done via autocomplete. Since reference data is usually stored in a centralized fashion, autocomplete algorithms usually run in client-server architectures and face strict time requirements.

In this article, a new autocomplete task decomposition is formulated using an existing method based on range minimum queries (RMQ). The Top-k RMQ problem is formulated and used in the autocomplete problem decomposition. A segment tree based algorithm is proposed for the Top-k RMQ problem. While the conventional segment tree based RMQ algorithm when used in autocomplete (in the Top-k RMQ subproblem) repeatedly processes the same nodes on the tree, the proposed algorithm is adapted directly to the Top-k RMQ problem and does not require any node of the segment tree to be processed more than twice. A complexity analysis is made for both the new Top-k RMQ algorithm and the conventional segment tree-based RMQ approach. This analysis considers different implementations of priority queues used in these algorithms, specifically binary heaps and ordered arrays. The new algorithm has time complexity that is not lower than that of the conventional algorithms with any priority queue implementation.

To prove the practical value of the new algorithm, a series of experiments was conducted using the data from the All-Russian Classifier of Addresses - a practical source of reference data for Russian address inputs. The new algorithm demonstrates better time efficiency than the conventional one in all experiments with all priority queue implementations.
\end{abstract}

Key words: All-Russian Classifier of Addresses, autocomplete, segment tree, range minimum query (RMQ), top $k$ range minimum query (Top-k RMQ), algorithm.

Citation: Dvoretckii M.S. (2017) A segment tree based Top-k RMQ algorithm and its application to the autocomplete problem. Business Informatics, no. 1 (39), pp. 48-54. DOI: 10.17323/1998-0663.2017.1.48.54.

\section{Introduction}

$\mathrm{B}$ usiness applications are constantly dealing with master data, i.e. data containing key business information not associated with specific business transactions [1]. Master data can be data on people, organizations, production processes, etc. For master data processing, it is important to maintain its uniform- ity in order to avoid generation of multiple records corresponding to similar things. To do this, master data is most often subject to validation according to various rules and is brought to some standard form that enables us to maintain quality of this data and exclude creation of duplicate records. On frequent occasions, this standard form in turn relies on some reference data. For exam- 
ple, for information on addresses in Russia, the standard is the All-Russian Classifier of Addresses (ARCA) [2], namely, a hierarchical directory correlating all address objects with positional numerical codes which uniquely represent address objects to a street level. A standardized line interpretation of the address also corresponds to this.

Operators entering master data into the database possibly do not know its canonical form. The best solution in this case is to issue variants of possible input information during the entry using autocomplete algorithms. Since the reference data management is ideally centralized, the programs which validate the data corresponding to the reference data and issue prompts for them, operate in a client-server mode. In this connection, the algorithm developed on the server side must be very fast, since an apparent delay in obtaining prompts reduces the convenience and performance of the entry, and the server itself must simultaneously solve a variety of problems for the associated workstations.

This article proposes that we modify the existing approach to autocomplete algorithms based on the decomposition of the autocomplete problem into binary search and range minimum query. A new statement is introduced for the range minimum query problem, and its solution algorithm is proposed using the segment tree. The algorithm efficiency is proved by its comparison with the existing autocomplete algorithm using the segment tree for the Range Minimum Query using data from ARCA.

\section{Autocomplete problem}

The term "autocomplete" is taken to mean a set of problems which can be extended to the following content-related statement: the user request is an incomplete form of some line (or lines) from an a-priori known applicant list; appropriate lines are issued from the applicant list in a certain form to the user, moreover, preferably the one (those) which the user originally wanted to receive. Algorithms solving autocomplete problems are used in search systems (to provide the user with the most frequently encountered or most anticipated queries), in information retrieval systems (to offer variants of responses to the user while the query is formed) and in mobile devices (to increase typing speed on touch keyboards). Autocomplete is also used when entering data into databases, to maintain uniformity of similar data in accordance with the reference data and prevent the occurrence of errors and duplicates.

Currently research in the autocomplete area is primarily aimed at development of effective error-tolerant au- tocomplete algorithms. However, for many applications of the autocomplete problem, including corresponding reference data to monitor the data input, it is quite enough to solve it in a classical prefix statement. Stringent response time requirements are generally imposed on the autocomplete algorithms. Ideally, the user should not notice a pause between the query input and response output.

\section{Statement of the autocomplete problem}

Let us provide a formal statement of the autocomplete problem by prefix.

Finite aggregate $W$ of the finite lines above finite alphabet $\Sigma$ is given:

$$
W=\left\{w_{i} \mid w_{i} \in \Sigma^{*}, i=\overline{0, n-1}\right\},
$$

on which weighting function $f(w): W \rightarrow \mathbf{R}$ is determined. For finite query $q \in \Sigma^{*}$ let us write down a set of its extensions from a number of lines in $W$ via $Q \subseteq W$ :

$$
Q=\left\{w_{i} \mid w_{i} \in W, \exists v_{i} \in \Sigma^{*}: w_{i}=q v_{i}\right\} .
$$

Put another way, $Q$ represents a set of lines from $W$, for which $q$ is a common prefix.

We need to find such a subset of extensions $R_{k} \subseteq Q$, which includes $k \in \mathbf{N}$ lines from $Q$, having the highest weight. In cases where $|Q| \leq k$ the task is trivial, and we assume that $R_{k}=Q$. If $|Q|>k$, then let us introduce set $B_{k}$ of all subsets of $Q$, having power $k$ in consideration:

$$
B_{k}=\{B|B \subset Q,| B \mid=k\} .
$$

For sets $B$ from $B_{k}$ let us determine price functional $C(\cdot): B_{k} \rightarrow \mathbf{R}:$

$$
C(B)=\sum_{w \in B} f(w) .
$$

Then the problem consists in finding such a subset $B^{*}$, which maximizes the price functional:

$$
R_{k}=B^{*}=\underset{B \in B_{k}}{\arg \max } C(B) .
$$

\section{Current approaches to solving the autocomplete problem}

While the more popular methods of solving the autocomplete problem are based on the use of prefix trees for fast-access retrieval of results, and also use caching responses to provide prompt query handling through additional memory requirements, one of the approaches to solving the autocomplete problem with low memory requirements set forth in [3] is decomposition of this 
problem into the problem of binary search by the direct index and Range Minimum Query (RMQ) in the maximization variant.

The range minimum query (RMQ) is a problem of finding a minimum element on a subset of consecutive array elements of comparable data structures. This problem is thoroughly studied primarily due to the fact that the problem of finding the lowest/least common ancestor (LCA) [4] reduces to it. Paper [5] describes some other applications of this problem, and also proposes its solution algorithm with time complexity $O(1)$ and space complexity $O(n)$ and proves its memory optimality with requirement $O(1)$ for the time complexity.

In order to solve the autocomplete problem, the RMQ problem is solved repeatedly in the maximization variant in order to obtain $k$ responses with a maximum weight from a number of variants suitable by prefix. Moreover, multiple RMQ-queries are made to the segments including each other.

Algorithm 1 given below describes a universal plan of using the existing algorithms for solving the autocomplete problem using RMQ. Here $W$ is a direct index, $T$ is a RMQ-structure on the weight array of the variants, $q$ is a query-prefix, $k$ is the number of expected results, $p q$ is a priority queue [6] of the segments in terms of the maximum weight of the variants thereon. In so doing, numerous RMQ-queries by segments including each other are performed, possibly leading to a large number of recurring actions.

Autocomplete_Algorithm $1(W, T, q, k \mid R k)$

$l, r \leftarrow$ Binary_search $(W, q)$

If Incorrect $(l, r)$

Return

range $\leftarrow$ Segment $(l, r, \operatorname{RMQ}(T, l, r))$

$p q \leftarrow \varnothing$

pq.Add(range)

$i \leftarrow 0$

While $i<k$ and no $p q$.Empty

range $\leftarrow p q$.GetTop ()

$R k$.Add(range.maxpos)

If (range.maxpos != range.l)

range $1 \leftarrow$ Segment $($ range.l, range.maxpos

$-1, \operatorname{RMQ}(T$, range.l, range.maxpos -1$))$

pq.Add(range 1$)$

If (range.maxpos != range.r)

range $2 \leftarrow$ Segment $($ range.maxpos +1, range.r, $\mathrm{RMQ}(T$, range.maxpos +1 , range.r))

$i \leftarrow i+1$

pq.Add(range2)

End of While Cycle

End of Algorithm.

\section{Approach to solving \\ the autocomplete problem \\ based on top $k$ range \\ minimum query (Top-k RMQ)}

The problem of finding the top- $k$ range minimum queries (Top-k RMQ) is set up in order to find a more effective algorithm for solving the autocomplete problem when using a similar decomposition principle, i.e. decomposition of the autocomplete problem into binary search problem and Top-k RMQ.

Therefore, the following statement is proposed. Let there be given a heap of numbers $A,|A|=n$, with elements $a_{i}, i=\overline{0, n-1}$, and two indexes $l$ and $r, 0 \leq l \leq r<n$.

For case $k>r-l$ the Top-k RMQ problem is solved by a set of all array $A$ indexes in segment $[l, r]-R_{k}=\{l, \ldots, r\}$.

In case $k \leq r-l$ the solution is a subset of indexing set $R_{k} \subset\{l, \ldots, r\}$ of power $k$, for which a sum of array elements $A$ is minimum:

$$
\begin{gathered}
B_{k}=\{B|B \subset\{l, \ldots, r\},| B \mid=k\}, \\
C(B)=\sum_{i \in B} a_{i}, \\
R_{k}=B^{*}=\underset{B \in B_{k}}{\arg \min } C(B) .
\end{gathered}
$$

As in the case of the classical RMQ problem, the statement of the Top-k RMQ problem can be changed to the problem of finding a subset with a maximum sum without a structural change of the algorithm.

In this case, the autocomplete problem is decomposed by the method given in algorithm 2. By comparison, algorithm 1 can be considered a reduction of Top-k RMQ to RMQ.

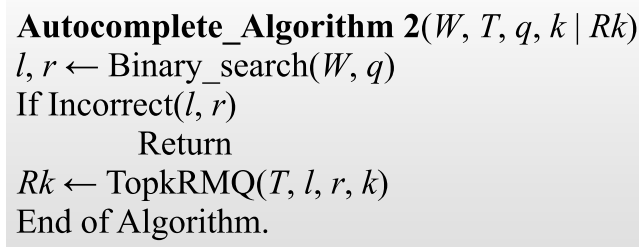

\section{Original algorithm based on segment trees}

The proposed algorithm is a modification of the variant of algorithm 1 which uses the segment tree [7] as the RMQ structure. This RMQ solution algorithm is not asymptotically the best one (query complexity $O(\ln n)$ for asymptotically better $O(1)$ ), but it is actively used for the 
autocomplete problem [8]. When using the segment tree as RMQ structure for the autocomplete problem, multiple RMQ queries for segments including each other result in a multiple rescanning of the same nodes at high tree levels. Due to changing the problem statement from pure RMQ to Top-k RMQ, these extra actions can be excluded.

Algorithm 3 uses a segment tree to solve the Top$\mathrm{k}$ RMQ problem in the maximization variant. In this case, not sub-segments, on which each next maximum is present (as in Algorithm 1), but nodes deriving from the way leading from the initial vertex to the maximum are put on the priority queue. In so doing, the segment tree property is used: the maximum in the internal vertex is always reached in at least one of its daughter vertices. When leaves are included in the segment tree 1, this property makes it possible to find the way from any vertex to the maximum in the segment corresponding to it.

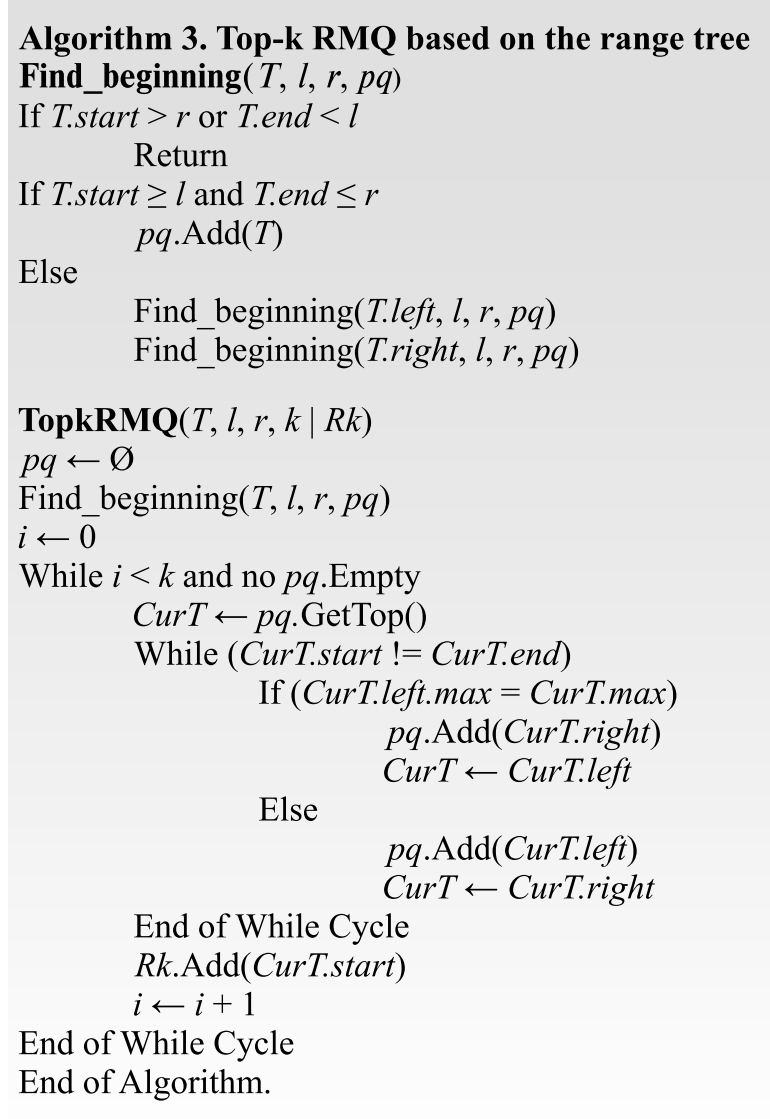

Contrary to algorithm 1, before the start of the solution search cycle, not one structure corresponding to the segment, but a set of segment tree vertices covering the segment at the highest level are put on the priority queue. In this case, a leaf corresponding to this value always exists for the vertex with the highest value, and instead of storing its location in the tree nodes, algorithm 3 provides for getting off to this leaf while putting all unconsidered vertices on the priority queue.

Keep in mind that as opposed to algorithm 1, where an RMQ query should have already been performed to put the segment on the priority queue, the new algorithm does not require any additional processing for the segment tree nodes. Furthermore, any segment tree node is considered no more than twice - when putting on the queue and selecting from it, while using the segment tree in algorithm 1 the root of this tree will be considered $k$ times, if the segment size is no less than $k$.

\section{Complexity assessment of the proposed algorithm}

By analogy with [3], let us define the algorithm complexity with symbol $\hat{O}$ with the assumption of complexity of operations with priority queue $O(1)$. Then excluding the binary search of the complexity of executing Top-k RMQ query per the scheme set forth in algorithm 1 using a standard algorithm RMQ on the segment tree is $\hat{O}(k \ln n)$, since on each of $k$ iterations no more than two RMQ queries are executed with complexity $O(\ln n)$. Algorithm 3 also has complexity $\hat{O}(k \ln n)$, inasmuch as on $k$ iterations a descent from the initial vertex to the tree leaf of $\left\lceil\log _{2} n\right\rceil+1$ high is executed .

Let us assume that the priority queue is implemented using the binary heap [6]. Then the operations of adding elements to the queue and reaching the maximum have complexity $O(\ln l)$, where $l$ is the queue length. Therefore, the computational complexity of executing Top-k RMQ by a classical method and algorithm 3 becomes equal to $O(k \ln k+k \ln n)$ and $O(k \ln n \cdot \ln (k \ln n))$, respectively. The highest asymptotic complexity of algorithm 3 is caused by the fact that in each internal vertex under consideration the daughter vertex not lying on the way to the maximum is put on the priority queue; that leads to overhead costs absent in algorithm 1, where in each of $k$ steps no more than two segments are put on the priority queue.

It should by also noted that for the binary heap there is no reliable method of limiting its permissible dimension, as its structure prevents us from determining its minimum element faster than during operations $O(l)$. However, no more than $k$ elements, one per step, 
are to be extracted from the priority queue for both solution algorithms to solve Top-k RMQ problem. In this case, it is handier to use a simpler variant of the priority queue, namely ordered length $k$ array. In this case, the operation of extracting the maximum is trivial: the shift is not required because of the assumption that the number of elements retrieved is limited, so that you can leave the maximum in place and move the top of the queue. An element is added with a linear insertion with complexity $O(k)$, and elements that are known to be out completely miss the queue (the best case). In this case, the complexities of the classical algorithm and algorithm 3 as a whole become equal to $O\left(k^{2}+k \ln n\right)$ and $O\left(k^{2} \ln n\right)$, respectively. For Algorithm 3 , this also enables us to reduce the amount of memory allocated to the priority queue. While the classical approach leads to the fact that at any step there are no more $k+1$ segments in the priority queue, for algorithm 3 in the worst case the number of vertices put on the queue is limited from above $\left\lceil(k+2) \log _{2} n\right\rceil$ (up to $2 \log _{2} n$ initial vertices, up to $\log _{2} n$ vertices are added on each of $k$ descents).

Note that the algorithm given above for using the array for the priority queue is not universal, since it uses a priori information on how many elements will be extracted from the queue. In general, the priority arraybased queue is to be either shifted when retrieving an element (complexity $O(l)$ ) or shall use a circular structure (which formally limits a number of items which can be stored in the queue or complicates the expansion operation).

For small sizes of entries encountered in practice, the greater asymptotic complexity is not an evidence of lack of practicality of the algorithm. To prove the practical value of a new algorithm and the validity of the new problem statement, let us perform an experimental comparison of the considered algorithms as components of a real-world autocomplete problem.

\section{Experimental results}

The experimental comparison of algorithms was carried out within the programs that solve the autocomplete problem of reference address lines from the All-Russian Classifier of Addresses (ARCA) [2], under the following conditions:

$\checkmark$ algorithms were software-implemented in C language and collected by compiler gcc5 using operating system Ubuntu 16.04 LTS with flag -lm; all components of the autocomplete algorithm, having nothing to do with Top-k RMQ problem are similarly implemented for both algorithms in both options;

$\downarrow$ the time of solution of the autocomplete problem is measured from the time of receiving the query to the time of issuing responses;

$\checkmark$ results were measured using the function clock_gettime() and high-resolution timer CLOCK_PROCESS CPUTIME_ID (specified resolution is $1 \mathrm{~ns}$ );

$\downarrow$ unloading of ARCA, including 1222662 address lines as a set of reference lines was used. The weight was calculated as the sum of a number of subordinated address elements and weights of upper elements with attenuation factors $0,1^{t}$, where $t$ is the difference in levels between the current and the upper elements;

$\checkmark$ a definite number of initial symbols from sequences of randomly selected lines from the reference set similar for both algorithms was taken as queries;

$\downarrow k=10$ was taken in all experiments;

$\downarrow$ All experiments were conducted using OS Ubuntu 16.04 LTS in sequence;

$\downarrow$ Computer hardware parameters:

$\diamond$ Processor Intel Core i3-4010U, $1.7 \mathrm{GHz}$

\section{$\diamond 4$ GB RAM}

Table 1 provides the experiment results. Note that the variants of algorithms with the priority queue in the form of an ordered array in all experiments proved to be more effective variants with a binary heap, and the new algorithm variants showed better results as compared to the variants of the classical approach.

\section{Conclusion}

The classical statement of an RMQ problem provides for obtaining only one minimum (maximum) value from the segment, and this is reflected by the existing algorithms for solution of the problem. For cases where it is necessary to extract more than one extreme value, transfer to a wider setting of Top-k RMQ makes it possible not only to more clearly extract this subproblem, but also to propose new algorithms for its solution, initially aimed at obtaining a set of results. Due to this, a new algorithm is created within the real autocomplete program that gives better results as compared to the algorithm created by the classical method based on the same data structure. 
Experimental results of implementations of algorithms of solving autocomplete problems

Table 1.

\begin{tabular}{|c|c|c|c|c|}
\hline Number of queries & $\begin{array}{l}\text { Classical algorithm, } \\
\text { binary heap, s }\end{array}$ & $\begin{array}{l}\text { Classical algorithm, } \\
\text { ordered array, s }\end{array}$ & $\begin{array}{l}\text { New algorithm, } \\
\text { binary heap, s }\end{array}$ & $\begin{array}{l}\text { New algorithm, } \\
\text { ordered array,s }\end{array}$ \\
\hline \multicolumn{5}{|c|}{ Queries of length 4} \\
\hline 1000 & 0.017555518 & 0.015670170 & 0.005854641 & 0.003890637 \\
\hline 10000 & 0.175507172 & 0.160802266 & 0.057827076 & 0.038593355 \\
\hline 100000 & 1.748508783 & 1.575862406 & 0.578767750 & 0.389285590 \\
\hline 1000000 & 17.494891590 & 15.630793271 & 5.787819119 & 3.892264716 \\
\hline \multicolumn{5}{|c|}{ Queries of length 10} \\
\hline 1000 & 0.017930115 & 0.016084878 & 0.006358041 & 0.004443302 \\
\hline 10000 & 0.179062306 & 0.160433853 & 0.062990764 & 0.044009557 \\
\hline 100000 & 1.786391754 & 1.604154774 & 0.630281282 & 0.440086321 \\
\hline 1000000 & 17.832476482 & 15.973139661 & 6.303791885 & 4.402448944 \\
\hline
\end{tabular}

\section{References}

1. Pavlyuts A. (2016) Master-dannye i upravlenie imi. Chto eto takoe i komu ono neobkhodimo? [Master data and master data management. What is it and who needs it?]. Available at: https://iqsystems.ru/master-data-basics-article/ (accessed 13 January 2017) (in Russian).

2. Klassifikator adresov Rossii (KLADR) [All-Russian Classifier of Addresses (ARCA)]. Available at: https://www.gnivc.ru/inf_provision/ classifiers_reference/kladr/ (accessed 13 January 2017) (in Russian).

3. Hsu B.-J., Ottaviano J. (2013) Space-efficient data structures for Top-k completion. Proceedings of the 22nd International World Wide Web Conference. Rio de Janeiro, Brazil, 13-17 May 2013. NY: ACM, pp. 583-594.

4. Fischer J., Heun V. (2006) Theoretical and practical improvements on the RMQ-problem, with applications to LCA and LCE. Proceedings of the 17th Annual Symposium on Combinatorial Pattern Matching (CPM 2006), Barcelona, Spain, 5-7 July 2006. Berlin, Heidelberg: Springer, pp. 36-48.

5. Fischer J., Heun V. (2007) A new succinct representation of RMQ-information and improvements in the enhanced suffix array. Proceedings of the First International Symposium on Combinatorics, Algorithms, Probabilistic and Experimental Methodologies (ESCAPE 2007). Hangzhou, China, 7-9 April 2007. Berlin, Heidelberg: Springer, pp. 459-470.

6. Knuth D. (1998) The art of computer programming. Vol. 3: Sorting and searching. Boston: Addison-Wesley Professional.

7. Matani D. (2011) An O(klogn) algorithm for prefix-based ranked autocomplete. Available at: http://www.dhruvbird.com/autocomplete.pdf (accessed 12 May 2016).

8. lib-face on GitHub. Available at: http://github.com/duckduckgo/cpp-libface (accessed 13 January 2017).

\section{Алгоритм нахождения $\boldsymbol{k}$ наименьших элементов на отрезке (Tор-k RMQ) на основе дерева отрезков и его применение в задачах автодополнения}

\section{М.С. Дворецкий}

студент магистратуры

Московский государственный университет им. М.В. Ломоносова;

программист, OOO «IQ Systems»

Адрес: 119991, г. Москва, Ленинские горы, д. 1

E-mail:mike.dvorecky@gmail.com 


\begin{abstract}
Аннотация
Контроль данных при вводе является важным способом обеспечения их качества. Одним из методов такого контроля является сопоставление вводимых данных, которые должны соответствовать справочной информации, непосредственно с этой информацией в процессе ввода. Это приводит к необходимости решения задачи автодополнения. Поскольку справочная информация, как правило, хранится централизованно, задача автодополнения решается в архитектуре клиент-сервер и к алгоритму ее решения предъявляются жесткие требования по быстродействию.

В данной статье на основе существующей декомпозиции задачи автодополнения с использованием задачи поиска минимума на отрезке (RMQ) формулируется задача поиска $k$ минимумов на отрезке (Top-k RMQ) и приводится алгоритм ее решения, использующий дерево отрезков. В то время как классический алгоритм RMQ по дереву отрезков при использовании в задаче автодополнения (в подзадаче Top-k RMQ) требует многократного посешения вершин дерева, близких к корню, предложенный алгоритм Top-k RMQ непосредственно адаптирован к этой задаче и не требует рассмотрения какой-либо вершины дерева отрезков более двух раз. Выполнен анализ сложности как алгоритма Top-k RMQ, так и классического алгоритма RMQ с использованием дерева отрезков. При этом учитываются различные варианты реализации приоритетных очередей, используемых в этих алгоритмах, а именно вариант двоичной кучи и простая приоритетная очередь на основе упорядоченного массива. Новый алгоритм имеет не меньшую вычислительную сложность, чем классический, при любой реализации приоритетной очереди.

Для доказательства ценности нового алгоритма произведено экспериментальное сравнение алгоритмов с использованием данных из Классификатора адресов России, представляющего собой реальный примера справочной информации. Во всех проведенных экспериментах новый алгоритм показал лучшие результаты по времени по сравнению с классическим.
\end{abstract}

Ключевые слова: Классификатор адресов России, автодополнение, дерево отрезков, поиск минимума на отрезке (RMQ), поиск $k$ наименьших элементов на отрезке (Top-k RMQ), алгоритм.

Цитирование: Dvoretckii M.S. A segment tree based Top-k RMQ algorithm and its application to the autocomplete problem // Business Informatics. 2017. No. 1 (39). P. 48-54. DOI: 10.17323/1998-0663.2017.1.48.54.

\title{
Литература
}

1. Павлюц А. Мастер-данные и управление ими. Что это такое и кому оно необходимо? [Электронный pecypc]: https://iqsystems.ru/masterdata-basics-article/ (дата обращения 13.01.2017).

2. Классификатор адресов России (КЛАДР) // ГНИВЦ. [Электронный pecypc]: https://www.gnivc.ru/inf_provision/classifiers_reference/kladr/ (дата обращения 13.01.2017).

3. Hsu B.-J., Ottaviano J. Space-efficient data structures for Top-k completion // Proceedings of the 22nd International World Wide Web Conference. Rio de Janeiro, Brazil, 13-17 May 2013. NY: ACM, 2013. P. 583-594.

4. Fischer J., Heun V. Theoretical and practical improvements on the RMQ-problem, with applications to LCA and LCE // Proceedings of the 17th Annual Symposium on Combinatorial Pattern Matching (CPM 2006), Barcelona, Spain, 5-7 July 2006. Berlin, Heidelberg: Springer, 2006. P. 36-48.

5. Fischer J., Heun V. A new succinct representation of RMQ-information and improvements in the enhanced suffix array // Proceedings of the First International Symposium on Combinatorics, Algorithms, Probabilistic and Experimental Methodologies (ESCAPE 2007). Hangzhou, China, 7-9 April 2007. Berlin, Heidelberg: Springer, 2007. P. 459-470.

6. Knuth D. (1998) The art of computer programming. Vol. 3: Sorting and searching. Boston: Addison-Wesley Professional, 1998.

7. Matani D. An $O(k \ln n)$ algorithm for prefix-based ranked autocomplete. [Электронный pecypc]: http://www.dhruvbird.com/autocomplete.pdf (дата обращения 12.05.2016).

8. lib-face на GitHub. [Электронный ресурс]: http://github.com/duckduckgo/cpp-libface (дата обращения 13.01.2017). 


\title{
Mathematical model and algorithm for selection of Internet sites and places for display of communication messages in planning advertising campaigns
}

\author{
Yuriy P. Yekhlakov \\ Professor, Head of Department of Data Processing Automation \\ Tomsk State University of Control Systems and Radioelectronics (TUSUR) \\ Address: 40, Prospect Lenina, Tomsk, 634050, Russian Federation \\ E-mail: upe@tusur.ru \\ Dmitriy N. Baraksanov \\ Senior Lecturer, Department of Data Processing Automation, \\ Tomsk State University of Control Systems and Radioelectronics (TUSUR) \\ Address: 40, Prospect Lenina, Tomsk, 634050, Russian Federation \\ E-mail:bdn@tusur.ru
}

Abstract

This paper discusses the problem of selecting a set of online marketing tools, advertising space, places and duration of display of advertising communications (AC) restricted by a tight advertising budget. The tool offered to evaluate the efficiency of AC display is the conversion rate. The paper reviews the methods for calculating the conversion rate. The formalized problem statement is represented as an integer valued linear programming model and reduced to maximization of the total conversion from advertising communications displayed under a tight advertising budget and with a limited selection of online marketing tools and duration of AC display.

The paper describes a solution algorithm based on the method of wave planning. It allows the decision maker to run an iterative decision making process in each interval of the planning period based on the AC conversion rate obtained at the previous stage. The authors propose methods for calculating input parameters for the model: $\mathrm{AC}$ display conversion rate, cost of AC placement in the advertising space over the shortest possible period, average number of AC displays over the shortest possible period.

The paper describes the results of experimental study of the model and the algorithm using the example of AC planning for Electronic Timetable software marketing to colleges and universities of the Kemerovo region. The results have practical value for executives and marketing managers of small innovation-based companies running advertising campaigns and planning communications with potential consumers using the tools of online marketing.

Key words: online marketing tool, advertising space, advertising communication, display conversion, integer model, wave planning.

Citation: Yekhlakov Yu.P., Baraksanov D.N. (2017) Mathematical model and algorithm for selection of Internet sites and places for display of communication messages in planning advertising campaigns. Business Informatics, no. 1 (39), pp. 55-60. DOI: 10.17323/1998-0663.2017.1.55.60

\section{Introduction}

$\mathrm{L}$ et us assume that a small IT company having a finished software product (SWP) is planning to bring it to market. At the same time, a basic market of potential users is determined, and its target segments are identified. SWP delivery options differentiated by functional and business models for each target market segment are formed, and the structure and composition of advertising communications focused on 
consumer preferences of the potential users are developed [1-4]. The company leaders face the task of developing a plan of marketing activities which includes an advertising campaign. Taking into account the high cost of traditional channels for dissemination of advertising (print media, radio, television, telephony and others), it is reasonable to use various online marketing tools, i.e. media advertising, contextual advertising, Internet-PR, participation in partner programs, promotion in social media, search engine optimization, address dispatch of advertisements as a channel of marketing specialists' communication with the target audience. Under these circumstances, the company management needs to solve the problem of selecting a set of online marketing tools, advertising spaces, display spaces and duration of posting advertising communications within the limited advertising budget.

\section{Statement of the problem}

In subsequent presentation, the following terminology is used. Advertising space is taken to mean an Internet resource on which an advertising communication can be posted. For spreading advertising communications, it is recommended to simultaneously use several advertising spaces. A specific place designated for display of advertising communications on the advertising space through a specific online marketing tool (display advertising, contextual advertising, Internet-PR and others) is a display position. According to recommendations [5, 6], the communication process should use several online marketing tools, for each of which a certain number of display positions can be available. The advertising campaign is carried out in a specified planning interval defining the duration of the communication impact on representatives of the target audience (number of days, weeks, months, quarters). For each display position, a minimum allowed interval of posting advertising communications is established. The duration of posting advertising communications for each display position is measured in units of the planning interval and is determined as the sum of minimum allowed posting intervals. Taking into account the effect of advertising "burn-out", it is necessary to limit the duration of posting the advertising communications for each display position [7].

Target action is an expected response of the target audience representatives to reading advertising communications: go to a website that contains information on SWP, download a SWP demo, execute an online-order for purchasing a SWP, etc. The effectiveness of displaying advertising communications in each position is assessed using the conversion rate, which may be calcu- lated according to the following options [6]:

$\checkmark$ relation of the number of users who received advertising communications to the total number of Internet users;

$\checkmark$ relation of the number of users who paid attention to the advertising communication to the number of users to whom it was delivered;

$\checkmark$ relation of the number of interested users to the number of users who paid attention to the advertising communication;

$\checkmark$ relation of the number of users who visited the SWP Internet resource to the number of interested users;

$\checkmark$ relation of the number of users who performed a target action on the SWP Internet resource to the number of visitors to the Internet resource;

$\checkmark$ relation of the number of users who revisited the Internet resource to the number of visitors.

In this case, in accordance with the stages of user interaction with the advertising communication (demonstration of advertising communication, highlighting, motivation, visiting the Website, action, repetition) listed in the literature [8], the conversion rate is calculated as the relation of the number of representatives of the target audience who performed a targeted action to the number of users who have contact with the advertising communication expressed as a percentage.

Based on the definitions introduced, the problem of selecting positions and duration of posting the advertising communications can be formulated in the form of the following mathematical model. Let us assume that assigned are: $R$ - advertising budget; $T$ - duration of the planning interval; $I=\{1, \ldots, n\}-$ a set of advertising spaces; $J=\{1, \ldots, m\}-$ a set of tools disseminating advertising communications; $L=\left\{l_{i j}\right\}, i=\overline{1, n}, j=\overline{1, m}-$ a set of available display positions in the $i$-th advertising space through the $j$-th tool.

In this case, each display position is characterized as follows:

$t_{i j p}$ - minimum allowed interval of posting the advertising communication in the $p$-th position;

$T_{i j p}$ - maximum duration of posting the advertising communication in the $p$-th position;

$c_{i j p}-$ advertising cost for a minimum allowed interval in the $p$-th position;

$v_{i j p}$ - average number of displays of the advertising communication for a minimum allowed interval of placement in the $p$-th position;

$k_{i j p}$ - display conversion in the $p$-th position. 
It is necessary to determine a set $X=\left\{x_{i j p}\right\}, i=\overline{1, n}, j=\overline{1, m}, p=\overline{1, l_{i j}}$ while maximizing the total conversion through displays of the advertising communications (1) and implementing a set of constraints $(2-5)$, where $x_{i j p}=\{0,1,2, \ldots, d\}$ is a number of minimum allowed intervals of posting the advertising communication in the $p$-th position of the $i$-th advertising space using the $j$-th tool in maximum achievement of a number of desired actions:

$$
Z=\sum_{i=1}^{n} \sum_{j=1}^{m} \sum_{p=1}^{l_{i j}} k_{i j p} \cdot x_{i j p} \cdot v_{i j p} \rightarrow \max .
$$

The total cost of posting the advertising communications should not exceed the advertising budget:

$$
\sum_{i=1}^{n} \sum_{j=1}^{m} \sum_{p=1}^{l_{i j}} c_{i j p} \cdot x_{i j p} \leq R .
$$

To disseminate advertising communications, all online marketing tools selected by decision-makers should be used:

$$
\sum_{i=1}^{n} \sum_{p=1}^{l_{i j}} x_{i j p} \geq 1, j=\overline{1, m}
$$

The duration of posting advertising communications on each advertising space using a specific tool should not exceed the duration of the planning interval:

$$
\sum_{p=1}^{l_{i j}} x_{i j p} \cdot t_{i p j} \leq T, i=\overline{1, n}, j=\overline{1, m} .
$$

The duration of posting advertising communications in each display position should not exceed the threshold set by the decision-maker:

$$
x_{i j p} \cdot t_{i p j} \leq T_{i p j}, \quad i=\overline{1, n}, j=\overline{1, m}, p=\overline{1, l_{i j}} .
$$

The mathematical model presented $(1-5)$ is an integer linear programming problem and can be solved using a table processor that is part of an office suite of applications (Microsoft office Excel, OpenOffice Calc and others) or specialized mathematical packages, including Linear Program Solver (LiPS) and MATLAB.

\section{Problem solution algorithm}

The algorithm is based on the wave planning procedure $[5,9]$. This selection is prompted by the lack of empirical data on the quality of communication actions at the stage of introducing a product to the market and possible inaccuracies in determining the average number of displays. The procedure consists in divid- ing the duration of the advertising campaign into short intervals (waves) and planning subsequent next wave after implementation of the previous one. This allows the company management to analyze the results obtained at the previous step, and to adjust the conversion projections for the next wave. In consideration of the foregoing, the algorithm for solving the problem of selecting advertising spaces and positions of advertising communications for each target segment can be presented as a sequence of steps.

Step 1. Determining the characteristics of the current wave. The decision-maker determines the current wave planning interval and specifies the duration of the planning interval, the amount of the advertising budget and the list of online marketing tools used for disseminating the advertising communications.

Step 2. Determining a list of display positions. The decision-maker selects a list of advertising spaces and possible display positions for each of them. The values of cost parameters for posting an advertising communication, minimum allowed placing interval and average amount of displays for an allowed posting interval are determined for each display position.

Step 3. Determining projected values of placement rates for advertising communications. The decision-maker specifies a projected display conversion and the maximum duration of placement for each display position.

Step 4. Selecting positions and duration of displays. The problem solution (5.1) using one of the software packages. The result obtained is taken to be the optimal plan of placing the advertising communications in the current planning interval.

Step 5. Implementing the posting plan. In accordance with the result obtained in Step 4, activities on posting the advertising communications are performed. During the advertising campaign, the decision-maker collects the achieved indicators and analyzes their deviations from the values predicted in Step 3.

Step 6. Planning the next wave. After implementing the current wave of the advertising communications plan, a transition to Step 1 with data correction in Steps 2 and 3 is performed, or a decision is taken on completion of the advertising campaign.

\section{Calculation methods for initial model parameters}

To predict the conversion rate, the Project Evaluation and Review Technique (PERT) will be used [10]. The essence of this technique is that in determining the pro- 
jected value of the conversion rate the decision-maker gives three estimations: $o$ - optimistic; $p$ - pessimistic; $b$ - realistic. The optimistic estimation of the conversion assumes that the advertising communication is implemented and posted in such a way that the target audience representatives will pay attention to it, be interested in the product and, with a high degree of probability, will perform a desired action. The pessimistic estimation of the conversion is made under the assumption that most of the receivers of the advertising communication will demonstrate little interest, and only a small part of them will perform a desired action. A realistic estimation of the conversion means the most probable estimation performed based on statistically average values of the conversions representative of the Internet marketing tools used. The average estimation of conversion prediction is determined by multiplying the realistic estimation by 4 , adding the optimistic and pessimistic estimations and dividing the result by 6 .

The cost of placing advertising communications is determined based on the existing cost models of advertising on the Internet. As of today, four basic cost models can be identified: a fixed cost for advertising for a certain period (Flat Fee Advertising, FFA), cost for a thousand displays of the advertising communication (Cost Per Thousand, $C P M$, where $M$ is a Roman designation of a thousand), Cost per Click $(C P C)$ and Cost per desired Action (CPA) [11].

In this case, the FFA model is used as a reference model for determining the cost parameter of posting advertising communications for the minimum allowed interval. Recalculation of the cost of advertising based on FFA models depending on other established models of advertising spaces is determined by the formulas $(6-8)$.

For $C P M$ model the formula is as follows

$$
C_{F F A}=\frac{V \cdot C_{C P M}}{1000},
$$

where $V$ - average number of displays of advertising communications for a minimum allowed posting interval;

$C C P M$ - fixed cost of a thousand displays.

For the $C P C$ model, the formula is as follows

$$
C_{F F A}=V \cdot C_{C P C} \cdot C T R,
$$

where $C_{C P C}-$ cost of one click;

$C T R$ - conversion of transitions ("clicks") relative to displays of advertising communication.

For the CPA model, the formula is as follows

$$
C_{F F A}=V \cdot C_{C P A} \cdot C T A,
$$

where $C_{C P A}-$ cost of a desired action;

CTA - conversion of performing desired actions to displays of advertising communication.

Data on the average number of displays for a certain period of time is generally published at advertising spaces, and can also be obtained from the owners of the advertising space or from statistical data of external systems of web analytics, such as Google Analytics, Yandex.Metrics, Liveinternet and others.

\section{Experimental studies}

The experimental studies of the proposed models and algorithms were conducted on the example of developing an advertising communications plan while promoting SWP "Electronic training agenda" in secondary schools and higher educational institutions of the Kemerovo region. To post advertising communications at advertising spaces of the news portal "GOROD NOVOSTEY. News Agency" (City-N.ru), portal "NCW (Independent City Website) Kemerovo" (ngs42.ru), Kemerovo's Newspaper (a42.ru), news portal "Electronic Kuzbass" (e-kuzbass.ru), the information-entertainment portal "KHUTOR" (hutor.ru) and the social network "Vkontakte" were selected. Media advertising and Internet-PR should be used as tools for advertising communications. The dimension of the problem of these initial data was 38 variables and 41 restrictions.

The following parameters have been identified for the first wave of the advertising plan:

$\downarrow$ duration of posting advertising communications -7 days;

$\checkmark$ advertising budget $-17,100$ rubles;

$\downarrow$ online marketing tools - Internet-PR and media advertising;

$\checkmark$ allowable display period - from 1 to 30 days;

$\downarrow$ maximum duration of displays - from 3 to 7 days;

$\downarrow$ projected conversion - from 0.001 to $0.02 \%$;

$\downarrow$ cost of posting FFA over the allowable planning interval - from 250 to 21,000 rubles.

As a result of solving the mathematical problem by means of a table processor of the office software suite LibreOffice Calc, the following decision was taken on arranging advertising communications for SWP promotion in the higher educational institutions in the Kemerovo Region: posting advertorials on news portals "GOROD NOVOSTEY" (city-n.ru) and "Electronic 
Kuzbass" (e-kuzbass.ru), media advertising for seven days on the news portal "GOROD NOVOSTEY," placing a banner and targeted advertising in the social network "Vkontakte," daily placement of four banners on the information and entertainment portal "KHUTOROK”. In so doing, the cost of the advertising budget was 17,047.4 rubles, the expected number of displays of advertising communications is $2,889.4$ thousands and the number of links to the site of SWP "Electronic training agenda service FlipTable.ru" is 392.

In experimental studies, the model was tested only during the planning of one advertising wave. For this reason, the impacts of changes in the decision-maker's projected conversion on the solution results in the next waves were not studied. With the expansion of practical use of the model, the study of this conformity may be of interest.

\section{Conclusion}

The mathematical model and algorithm presented for selecting positions for advertising communications and duration on Internet sites make it possible to increase the number of desired actions of potential SWP customers using a set of online marketing tools within a limited budget. On the practical level, use of the study results allows managers of small innovative enterprises to increase the effectiveness of advertising campaigns through sequential optimization of the projected conversion rates for desired actions of the target audience representatives.

\section{References}

1. Yekhlakov Yu.P., Baraksanov D.N. (2012) Osnovnye polozheniya po razrabotke programmy prodvizheniya programmnykh produktov v seti Internet [Main provisions on the development of the program of promotion of software products on the Internet]. Business Informatics, no. 4 (22), pp. 26-32 (in Russian).

2. Yekhlakov Yu.P., Baraksanov D.N. (2015) Mathematical model and algorithm of selecting software promotion options differentiated by functionality and business models. Business Informatics, no. 4 (34), pp. 54-61.

3. Yekhlakov Yu.P., Baraksanov D.N. (2015) Mnogokriterial'naya zadacha podderzhki prinyatiya resheniy pri vybore variantov postavki na tselevye rynki lineyki programmnykh produktov [The multicriteria decision support problem to choose delivery options for the line of software products to the target markets]. Proceedings of TUSUR University, no. 3 (37), pp. 114-119 (in Russian).

4. Yekhlakov Yu.P., Baraksanov D.N. (2016) Struktura i soderzhanie kommunikatsionnogo soobshcheniya pri organizatsii Internet-reklamy programmnykh produktov [The structure and content of the communication message for organization of online advertising software]. Internet Marketing, no. 3 (93), pp. 146-156 (in Russian).

5. Kak povysit' effektivnost' reklamnoy kampanii za schet volnovogo planirovaniya? [How to improve the effectiveness of advertising campaigns by the wave planning?]. Available at: http://infobusiness2.ru/node/9591 (accessed 22 June 2016) (in Russian).

6. Virin F. (2010) Internet-marketing. Polnyy sbornik prakticheskikh instrumentov [Internet marketing. The complete collection of practical tools]. Moscow: Eksmo (in Russian).

7. Virin F. (2003) Vygoranie reklamy [Burnout of advertising]. Available at: http://www.getinfo.ru/article163.html (accessed 22 June 2016) (in Russian).

8. SEOnews (2007) Metodologiva otsenki effektivnosti reklamnoy kampanii v Internete [Methodology for evaluating the effectiveness of an advertising campaign on the Internet] Available at: http://www.seonews.ru/ analytics/detail/6660.php (accessed 22 June 2016) (in Russian).

9. Trufanov M. (2009) Osobennosti planirovaniya reklamnykh kampaniy $v$ Internet [Features of planning advertising campaigns on the Internet]. Available at: http://www.arton.ru/articles/214 (accessed 22 June 2016) (in Russian).

10. Fatrell R., Shafer D., Shafer L. (2004) Upravlenie programmnymi proektami. Dostizhenie optimal'nogo kachestva pri minimume zatrat [Software project management. Achieving optimal quality at the lowest cost]. Moscow: Williams (in Russian).

11. Yurasov A.V. (2008) Osnovy elektronnoy kommertsii [Basics of e-commerce]. Moscow: Hot Line - Telecom (in Russian).

\section{Математическая модель и алгоритм выбора Интернет- площадок и мест размещения коммуникационных сообщений при организации рекламных кампаний}

\section{Ю.П. Ехлаков}

доктор технических наук, профессор

заведующий кафедрой автоматизации обработки информации

Томский государственный университет систем управления и радиоэлектроники (ТУСУР)

Адрес: 634050, г. Томск, пр. Ленина, д. 40

E-mail: upe@tusur.ru 


\section{Д.Н. Бараксанов}

старший преподаватель кафедры автоматизации обработки информации

Томский государственный университет систем управления и радиоэлектроники (ТУСУР)

Адрес: 634050, г. Томск, пр. Ленина, д. 40

E-mail:bdn@tusur.ru

\section{Аннотация}

В статье рассмотрена задача выбора комплекса инструментов Интернет-маркетинга, рекламных площадок, мест показа и продолжительности размещения на них коммуникационных сообщений в условиях ограниченного рекламного бюджета. Результативность показов на каждом месте предлагается оценивать с помощью показателя конверсии. Приведен обзор вариантов расчета показателя конверсии. Формализованная постановка задачи представлена в виде целочисленной модели линейного программирования и сведена к максимизации суммарной конверсии от показа коммуникационных сообщений при ограничениях на размер рекламного бюджета, количество используемых инструментов Интернет-маркетинга, продолжительность их размещения на рекламных площадках и местах показа.

Описан алгоритм решения задачи, в основу которого положена методика волнового планирования. Это позволяет лицу, принимающему решение (ЛПР), организовать итерационный процесс поиска решения в каждом интервале планируемого периода с учетом полученной на предыдущем шаге конверсии показа. Предложены методы расчета исходных параметров модели: конверсий показов, стоимости размещения коммуникационных сообщений на рекламной площадке за минимально допустимый интервал размещения, среднего количества показов за минимально допустимый интервал.

Описаны результаты экспериментальных исследований модели и алгоритма на примере разработки плана размещения коммуникационных сообщений при продвижении программного продукта (ПП) «Электронное расписание занятий» в ссузах и вузах Кемеровской области. В практическом плане полученные результаты могут быть полезны руководителям и маркетологам малых инновационных предприятий при проведении рекламных кампаний и планировании мероприятий по коммуникационному воздействию на потенциальных потребителей с использованием комплекса инструментов Интернет-маркетинга.

Ключевые слова: инструмент Интернет-маркетинга, рекламная площадка, коммуникационное сообщение, конверсия показа, целочисленная модель, волновое планирование.

Цитирование: Yekhlakov Yu.P., Baraksanov D.N. Mathematical model and algorithm for selection of Internet sites and places for display of communication messages in planning advertising campaigns // Business Informatics. 2017. No. 1 (39). P. 55-60. DOI: 10.17323/1998-0663.2017.1.55.60.

\section{Литература}

1. Ехлаков Ю.П., Бараксанов Д.Н. Основные положения по разработке программы продвижения программных продуктов в сети Интернет // Бизнес-информатика. 2012. № 4 (22). С. 26-32.

2. Yekhlakov Yu.P., Baraksanov D.N. Mathematical model and algorithm of selecting software promotion options differentiated by functionality and business models // Business Informatics. 2015. No. 4 (34). P. 54-61.

3. Ехлаков Ю.П., Бараксанов Д.Н. Многокритериальная задача поддержки принятия решений при выборе вариантов поставки на целевые рынки линейки программных продуктов // Доклады Томского государственного университета систем управления и радиоэлектроники. 2015. № 3 (37). С. 114-119.

4. Ехлаков Ю.П., Бараксанов Д.Н. Структура и содержание коммуникационного сообщения при организации Интернет-рекламы программных продуктов // Интернет-маркетинг. 2016. № 3 (93). С. 146-156.

5. Как повысить эффективность рекламной кампании за счет волнового планирования? Фрагмент занятия мастер-группы «Интернет-продажи». [Электронный ресурс]: http://infobusiness2.ru/node/9591 (дата обращения: 22.06.2016).

6. Вирин Ф.Ю. Интернет-маркетинг. Полный сборник практических инструментов. М.: Эксмо, 2010.

7. Вирин Ф.Ю. Выгорание рекламы / Компьютерная библиотека GetInfo.Ru. [Электронный pecypc]: http://www.getinfo.ru/article163.html (дата обращения: 22.06.2016).

8. Методология оценки эффективности рекламной кампании в Интернете / SEOnews. Издание о поисковом маркетинге и заработке в Интернете. [Электронный ресурc]: http://www.seonews.ru/ analytics/detail/6660.php (дата обращения: 22.06.2016).

9. Труфанов М. Особенности планирования рекламных кампаний в Интернет / ARTON. [Электронный pecypc]: http://www.arton. ru/articles/214 (дата обращения: 22.06.2016).

10. Фатрелл Р.Т., Шафер Д.Ф., Шафер Л.И. Управление программными проектами. Достижение оптимального качества при минимуме затрат. М.: Вильямс, 2004.

11. Юрасов А.В. Основы электронной коммерции: учебник для вузов. М.: Горячая линия - Телеком, 2008. 


\title{
Design of fuzzy rule based classifier using the monkey algorithm ${ }^{1}$
}

\author{
Ilya A. Hodashinsky \\ Professor, Department of Complex Information Security of Computer Systems \\ Tomsk State University of Control Systems and Radioelectronics (TUSUR) \\ Address: 40, Prospect Lenina, Tomsk, 634050, Russian Federation \\ E-mail:hodashn@rambler.ru
}

\section{Sergey S. Samsonov}

Student, Department of Complex Information Security of Computer Systems Tomsk State University of Control Systems and Radioelectronics (TUSUR) Address: 40, Prospect Lenina, Tomsk, 634050, Russian Federation

E-mail: samsonicx@mail.ru

\begin{abstract}
This article presents an approach for building fuzzy rule based classifiers. A fuzzy rule-based classifier consists of IF-THEN rules with fuzzy antecedents (IF-part) and the class marks in consequents (THEN-part). Antecedent parts of the rules break down the input feature space into a set of fuzzy areas, and consequents define the classifier exit, marking these areas with a class mark. Two main phases of building the classifier are selected: generating the fuzzy rule base and optimizing the rule antecedent parameters. The classifier structure was formed by an algorithm for generating the rule base by extreme features found in the training sample. The peculiarity of this algorithm is that it is generated according to one classification rule for each class. The rule base formed by this algorithm has as low as practicable size in classification of a given data set. The optimization of parameters of antecedents of the fuzzy rules is implemented using the monkey algorithm adapted for these purposes, which is based on observations of monkey migration in the highlands. In the process of the algorithm work, three operations are performed: climb process, watch jump process and somersault process. One of the algorithm's advantages in solution of high-dimension optimization problems is calculation of the pseudogradient of the objective function. Irrespective of the dimension at each iteration of the algorithm execution only two values of the objective function are to be calculated.

The effectiveness of fuzzy rule-based classifiers built with the use of the proposed algorithms was checked on actual data from the KEEL-dataset repository. A comparative analysis was conducted using the known analog algorithms "D-MOFARC" and "FARC-HD". The number of rules used by the classifiers built with the use of the algorithms so developed is much lower than the number of rules in analog classifiers with a comparable classification accuracy, that points to the highest interpretability of the classifiers built with the use of the proposed approach.
\end{abstract}

Key words: fuzzy classifier, optimization of fuzzy parameters, monkey algorithm, fuzzy rule extraction.

Citation: Hodashinsky I.A., Samsonov S.S. (2017) Design of fuzzy rule based classifier using the monkey algorithm. Business Informatics, no. 1 (39), pp. 61-67. DOI: 10.17323/1998-0663.2017.1.61.67.

\section{Introduction}

$\mathrm{F}$ luzzy rule based classifiers belong to a class of fuzzy rule-based systems. Classifiers of this type are widely used in modern business applications due to their ability to manage uncertainty, inaccuracy and incompleteness of information [1], for example, in such areas as credit risk assessment [2,3], marketing $[4,5]$, electronic business and e-commerce [6]. The

\footnotetext{
${ }^{1}$ This work was supported by the Ministry of Education and Science of the Russian Federation, agreement no. 8.9628.2017/BP
} 
advantages of the fuzzy rule-based classifiers include their good interpretability [7] and lack of assumptions required for statistical classification [8].

Construction of fuzzy rule-based classifiers involves the solution of two main problems: generating the fuzzy rule base and optimizing the rule antecedent parameters (IF-parts). To generate a fuzzy rule base, clustering algorithms are most often used, resulting in formation of the initial "rude" approximation of the fuzzy rule-based classifier. The procedure for optimization of rule antecedent parameters or "fine" tuning is generally performed through derivatives, swarm intelligence algorithms or evolutionary computations [1, 2, 9-14]. For solution of the problems listed above, this paper proposes to use the algorithm of generating the rule base by extreme features and the monkey algorithm.

Application of the algorithm for generating the rule base for extreme values of features enables us to minimize the number of rules to the number of classes, and so to increase the interpretability of the result.

The monkey algorithm is based on the observation of monkey migration in the highlands [15]. In the process of the algorithm work, three operations are performed: climb process, watch jump process and somersault process. One of the algorithm advantages in solution of highdimension optimization problems is calculation of the pseudo-gradient of the objective function. Irrespective of the dimension at each iteration of the algorithm execution, only two values of the objective function are to be calculated [16].

The purpose of this paper is to describe the algorithms of building fuzzy rule-based classifiers: the algorithm for generating rule base by extreme features and the monkey algorithm. Application of these algorithms is aimed at increasing the accuracy in solving classification problems, while maintaining the interpretability of the solution obtained.

\section{Statement of the problem}

Let us assume that we have universum $U=(A, C)$, where $A=\left\{x_{1}, x_{2}, \ldots, x_{n}\right\}$ is a set of input features, $C=\left\{c_{1}, c_{2}, \ldots, c_{m}\right\}$ is a set of classes. Suppose $\mathbf{X}=x_{1} \cdot x_{2} \cdot \ldots \cdot x_{n} \in \Re^{n}$ is an $\mathrm{n}$-dimensional space of feature values. Object $u$ in this universum is characterized by its vector of feature values. The classification problem consists in prediction of object class $u$ by its vector of feature values.

The traditional classifier can be defined as a function of

$$
f: \Re^{n} \rightarrow\{0,1\}^{m},
$$

where $f(\mathbf{x} ; \boldsymbol{\theta})=\left(c_{1}, c_{2}, \ldots, c_{m}\right)$, where $c_{i}=1$, and $c_{j}=0$ $(j \in[1, m], i \neq j)$, when the object specified by vector $\mathbf{x}$ belongs to class $c_{i}$;

$$
\boldsymbol{\theta}-\text { vector of the classifier parameters. }
$$

The fuzzy rule-based classifier can be presented in a functional form, which assigns a point in the input feature space with a class mark with the calculated level of confidence:

$$
f: \Re^{n} \rightarrow[0,1]^{m} .
$$

The fuzzy rule-based classifier is based on a production rule of the form:

$$
\begin{gathered}
R_{i j}: \operatorname{IF} x_{1}=\mathrm{A}_{1 i} \text { И } x_{2}=\mathrm{A}_{2 i} \text { И } x_{3}=\mathrm{A}_{i} \text { И ..И } x_{N}=A_{n i} \\
\text { THEN class }=c_{j},
\end{gathered}
$$

where $A_{k i}$ - fuzzy term characterizing the $k$-th feature in the $i$-th rule $(i \in[1, R])$;

$R$ - number of rules.

In this paper, the class is determined on the principle "a winning team gets everything":

$$
\text { class }=c_{j^{*}}, j^{*}=\arg \max _{1 \leq j \leq m} \beta_{j},
$$

where $\beta_{j}(\mathbf{x})=\sum_{R_{i j}} \prod_{k=1}^{n} \mu_{A_{j k}}\left(x_{k}\right), j=1,2, \ldots, m ;$

$\mu_{A}(\cdot)$ - membership function of fuzzy term $A$.

Let us assume that there is a table of observations $\left\{\left(\mathbf{x}_{p} ; c_{p}\right), p=1, \ldots, Z\right\}$. Let us determine the following unit function:

$$
\operatorname{delta}(p, \boldsymbol{\theta})=\left\{\begin{array}{l}
1, \text { if } c_{p}=f\left(c_{p}, \boldsymbol{\theta}\right) \\
0, \quad \text { otherwise }
\end{array}, p=1,2, \ldots, Z .\right.
$$

Then the fitness function or the classifier precision measure can be expressed in the following way:

$$
E(\boldsymbol{\theta})=\frac{\sum_{p=1}^{Z} \operatorname{delta}(p, \boldsymbol{\theta})}{Z} .
$$

The problem of building a fuzzy rule-based classifier comes down to finding the maximum of the specified function in space $\boldsymbol{\theta}=\left(\theta_{1}, \theta_{2}, \ldots, \theta_{D}\right)$ :

$$
\max (E(\boldsymbol{\theta})), \theta_{i} \in\left\{\Theta_{i}: \Theta_{i, \text { min }}<\Theta_{i}<\Theta_{i, \text { max }}, i=1,2, \ldots, D\right\},
$$

where $\Theta_{i}-$ value of parameter $\theta_{i}$ from the interval $\left[\Theta_{i, \text { min }}, \Theta_{i, \text { max }}\right]$;

$\Theta_{i, \text { min }}, \Theta_{i, \max }-$ lower and upper limits of each parameter, respectively.

Figure 1 depicts an example explaining the formation of vector $\boldsymbol{\theta}$. At this time, variable $x_{1}$ is presented by three 
triangular terms, each of which is represented by three parameters $(a, b, c)$, included in vector $\boldsymbol{\theta}=\left(a_{11}, b_{11}, c_{11}\right.$, $\left.a_{12}, b_{12}, c_{12}, a_{13}, b_{13}, c_{13}, \ldots a_{21}, b_{21}, c_{21}, \ldots\right)$.

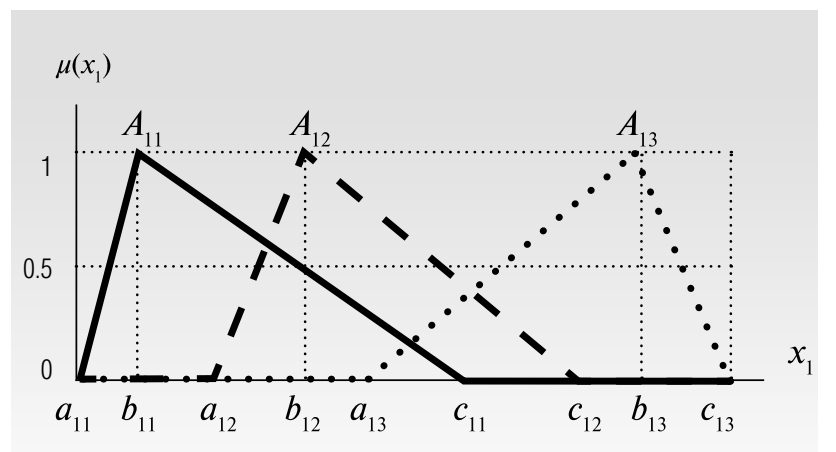

Fig. 1. Fuzzy partition of variable $x_{1}$

For finding optimal parameters $\boldsymbol{\theta}$, we propose using the monkey algorithm.

\section{Monkey algorithm}

The monkey algorithm (MA) is a metaheuristic optimization algorithm simulating the migration of a monkey population in the highlands. Seven main stages of algorithms are considered below.

\section{1) Solutions coding}

First, $M$ - a magnitude of monkey population is determined, in which the position of each $i$-th monkey presents the solution specified by vector $\boldsymbol{\theta}_{i}=\left(\theta_{i 1}, \theta_{i 2}, \ldots, \theta_{i D}\right)$, $i=1, \ldots, M$.

\section{2) Initialization of population}

Possible positions of monkeys in a $D$-dimensional hypercube are generated in random manner, or position-solutions are given by the user. A mixed strategy of initialization is also possible, when one part of the population is defined by the user, and the other part is randomly generated.

\section{3) Climb process}

I. For each $i$-th monkey vector $\Delta \boldsymbol{\theta}_{i}=\left(\Delta \theta_{i 1}, \Delta \theta_{i 2}, \ldots, \Delta \theta_{i D}\right)$ is generated, where

$$
\begin{gathered}
\Delta \theta_{i j}=\left\{\begin{array}{c}
a, \text { if } \operatorname{rand}(0 ; 1) \geq 0,5 \\
-a, \text { if } \operatorname{rand}(0 ; 1)<0,5
\end{array}, i=1, \ldots, M, j=1, \ldots, D,\right. \\
\quad a>0 \text { is a step length. }
\end{gathered}
$$

\section{Calculate}

$$
E_{i j}^{\prime}\left(\boldsymbol{\theta}_{i}\right)=\frac{E\left(\boldsymbol{\theta}_{i}+\Delta \boldsymbol{\theta}_{i}\right)-E\left(\boldsymbol{\theta}_{i}-\Delta \boldsymbol{\theta}_{i}\right)}{2 \Delta \theta_{i j}}, i=1, \ldots, M, j=1, \ldots, D .
$$

Vector $\mathbf{E}_{i}^{\prime}\left(\boldsymbol{\theta}_{i}\right)=\left(E_{i 1}^{\prime}\left(\boldsymbol{\theta}_{i}\right), E_{i 2}^{\prime}\left(\boldsymbol{\theta}_{i}\right), \ldots, E_{i D}^{\prime}\left(\boldsymbol{\theta}_{i}\right)\right)$ is a pseudo-gradient of fitness function $E(\cdot)$ in point $\boldsymbol{\theta}_{i}$.

III. Calculate $z_{j}=\theta_{i j}+a \cdot \operatorname{sign}\left(E_{i j}^{\prime}\left(\boldsymbol{\theta}_{i}\right)\right)$ and form vector $\mathbf{z}=\left(z_{1}, z_{2}, \ldots, z_{D}\right)$.

IV. If the obtained solution vector $\mathbf{z}$ is compatible with the limits of building the fuzzy rule-based classifier, vector $\boldsymbol{\theta}_{i}$ is replaced with vector $\mathbf{z}$; otherwise, vector $\boldsymbol{\theta}_{i}$ remains unchanged.

V. Repeat Steps I-IV a specified number of times.

\section{4) Watch jump process}

I. Form vector $\mathbf{z}=\left(z_{1}, z_{2}, \ldots, z_{D}\right)$ of the randomly generated uniformly distributed real numbers in the range $\left(\theta_{i j}-b, \theta_{i j}+b\right)$, where $b$ is a parameter characterizing the monkey's ability to observe.

II. If value $E(\mathbf{z})>E\left(\boldsymbol{\theta}_{i}\right)$ and vector $\mathbf{z}$ are compatible with the requirements of constructing a fuzzy rule-based classifier, then vector $\boldsymbol{\theta}_{i}$ is replaced with vector $\mathbf{z}$.

III. Repeat Steps I-II a specified number of times.

\section{5) Somersault process}

I. Generate a random evenly distributed real number $\alpha$ from the interval $[c, d]$, where $c, d$ are algorithm parameters.

II. Calculate $z_{j}=\theta_{i j}+\alpha \cdot\left(\rho_{j}-\theta_{i j}\right), j=1,2, \ldots, D$, where $\rho_{j}=\frac{\sum_{i=1}^{M} \theta_{i j}}{M}, i=1, \ldots, M, j=1, \ldots, D$.

III. If the obtained vector $\mathbf{z}=\left(z_{1}, z_{2}, \ldots, z_{D}\right)$ is compatible with the requirements of constructing a fuzzy rulebased classifier, and value $E(\mathbf{z})>E\left(\boldsymbol{\theta}_{i}\right)$, then vector $\boldsymbol{\theta}_{i}$ is replaced with vector $\mathbf{z}$; otherwise, vector $\boldsymbol{\theta}_{i}$ remains unchanged.

IV. Repeat Steps I-III a specified number of times.

6) Repeat $N$ times the climb process operators, watch jump and somersault processes

\section{7) Output of the best solution}

\section{Algorithm for generating rule base by extreme features}

The algorithm for generating rule base by extreme features (EC) is intended to form the initial rule base of the fuzzy rule-based classifier containing one rule at a time for each class. The rules are laid down based on extreme values of training sample $\left\{\left(\mathbf{x}_{p} ; t_{p}\right), p=1, \ldots, Z\right\}$. Let us introduce the following designations: $m$ is a number of classes, $n$ is a number of features, $\boldsymbol{\Omega}^{*}$ is a classifier rule base. 
Table 1.

\section{Description of data sets}

\begin{tabular}{|c|c|c|c|c|}
\hline Group & Name & Features & Copies & Classes \\
\hline \multirow{8}{*}{ SS } & 1. haberman & 3 & 306 & 2 \\
\hline & 2. iris & 4 & 150 & 3 \\
\hline & 3. balance & 4 & 625 & 3 \\
\hline & 4. newthyroid & 5 & 215 & 3 \\
\hline & 5. bupa & 6 & 345 & 2 \\
\hline & 6. pima & 8 & 768 & 2 \\
\hline & 7. glass & 9 & 214 & 7 \\
\hline & 8. Wisconsin & 9 & 683 & 2 \\
\hline \multirow{5}{*}{ SL } & 9. banana & 2 & 5300 & 2 \\
\hline & 10. titanic & 3 & 2201 & 2 \\
\hline & 11. phoneme & 5 & 5404 & 2 \\
\hline & 12. magic & 10 & 19020 & 2 \\
\hline & 13. page-blocks & 10 & 5472 & 5 \\
\hline \multirow{4}{*}{ LS } & 14. wine & 13 & 178 & 3 \\
\hline & 15. Cleveland & 13 & 297 & 5 \\
\hline & 16. heart & 13 & 270 & 2 \\
\hline & 17. hepatitis & 19 & 80 & 2 \\
\hline \multirow{3}{*}{ LL } & 18. segment & 19 & 2310 & 7 \\
\hline & 19. twonorm & 20 & 7400 & 2 \\
\hline & 20. thyroid & 21 & 7200 & 3 \\
\hline
\end{tabular}

Input: $m,\left\{\left(\mathbf{x}_{p} ; t_{p}\right)\right\}$.

Output: Classifier rule base $\boldsymbol{\Omega}^{*}$.

$\mathbf{\Omega}:=\varnothing$

Loop on $j$ from 1 to $m$

Loop on $k$ from 1 to $n$

search min class $_{j k}:=\min _{p}\left(x_{p k}\right)$;

search max class ${ }_{j k}:=\max _{p}\left(x_{p k}\right)$;

forming fuzzy term $A_{j k}$, covering

the interval

$\left[\right.$ minclass $_{j k}$, maxclass $_{j k}$ ];

Loop end

Creating rule $R_{1 j}$ based on terms $A_{j k}$, re-

ferring

the observation to a class with identifier $c_{j}$;

$$
\boldsymbol{\theta}^{*}:=\boldsymbol{\theta} \cup\left\{R_{1 j}\right\} ;
$$

Loop end

Output $\boldsymbol{\theta}^{*}$

Table 2.

\section{Comparison of classifiers on KEEL data sets}

\begin{tabular}{|c|c|c|c|c|c|c|c|c|c|c|}
\hline \multicolumn{2}{|c|}{ Data set } & \multicolumn{3}{|c|}{ EC+MA } & \multicolumn{3}{|c|}{ D-MOFARC } & \multicolumn{3}{|c|}{ FARC-HD } \\
\hline Group & Name & $\# \mathrm{R}$ & \#L & $\# T$ & $\# R$ & $\# \mathrm{~L}$ & $\# T$ & \#R & $\# \mathrm{~L}$ & $\# T$ \\
\hline \multirow{8}{*}{ SS } & 1. haberman & 2 & 79.2 & 73.8 & 9.2 & 81.7 & 69.4 & 5.7 & 79.2 & 73.5 \\
\hline & 2. iris & 3 & 97.8 & 95.3 & 5.6 & 98.1 & 96.0 & 4.4 & 98.6 & 95.3 \\
\hline & 3. balance & 3 & 87.5 & 86.7 & 20.1 & 89.4 & 85.6 & 18.8 & 92.2 & 91.2 \\
\hline & 4. newthyroid & 3 & 97.5 & 90.7 & 9.5 & 99.8 & 95.5 & 9.6 & 99.2 & 94.4 \\
\hline & 5. bupa & 2 & 74.2 & 68.4 & 7.7 & 82.8 & 70.1 & 10.6 & 78.2 & 66.4 \\
\hline & 6. pima & 2 & 75.5 & 71.3 & 10.4 & 82.3 & 75.5 & 20.2 & 82.3 & 76.2 \\
\hline & 7. glass & 7 & 69.0 & 61.3 & 27.4 & 95.2 & 70.6 & 18.2 & 79.0 & 69.0 \\
\hline & 8. wisconsin & 2 & 96.8 & 96.4 & 9.0 & 98.6 & 96.8 & 13.6 & 98.3 & 96.2 \\
\hline \multirow{5}{*}{ SL } & 9. banana & 2 & 78.9 & 78.4 & 8.7 & 90.3 & 89.0 & 12.9 & 86.0 & 85.5 \\
\hline & 10. titanic & 2 & 78.5 & 78.0 & 10.4 & 78.9 & 78.7 & 4.1 & 79.1 & 78.8 \\
\hline & 11. phoneme & 2 & 79.9 & 79.3 & 9.3 & 84.8 & 83.5 & 17.2 & 83.9 & 82.4 \\
\hline & 12. magic & 2 & 81.2 & 81.0 & 32.2 & 86.3 & 85.4 & 43.8 & 85.4 & 84.8 \\
\hline & 13. page-blocks & 5 & 95.5 & 95.3 & 21.5 & 97.8 & 97.0 & 18.4 & 95.5 & 95.0 \\
\hline \multirow{4}{*}{ LS } & 14. wine & 3 & 99.0 & 96.6 & 8.6 & 100.0 & 95.8 & 8.3 & 100.0 & 95.5 \\
\hline & 15. cleveland & 5 & 60.7 & 57.1 & 45.6 & 90.9 & 52.9 & 42.1 & 82.2 & 58.3 \\
\hline & 16. heart & 2 & 75.8 & 74.4 & 18.7 & 94.4 & 84.4 & 27.8 & 93.1 & 83.7 \\
\hline & 17. hepatitis & 2 & 94.1 & 77.8 & 11.4 & 100.0 & 90.0 & 10.4 & 99.4 & 88.7 \\
\hline \multirow{3}{*}{ LL } & 18. segment & 7 & 85.8 & 84.0 & 26.2 & 98.0 & 96.6 & 41.1 & 94.8 & 93.3 \\
\hline & 19. twonorm & 2 & 97.5 & 97.1 & 10.2 & 94.5 & 93.1 & 60.4 & 96.6 & 95.1 \\
\hline & 20. thyroid & 3 & 99.6 & 99.3 & 5.9 & 99.3 & 99.1 & 4.9 & 94.3 & 94.1 \\
\hline
\end{tabular}




\section{Experiment}

For assessing the operating efficiency of the fuzzy rule-based classifiers optimized by a combination of the above algorithms (EC+MA), tests were conducted on data sets from the KEEL repository given in Table 2. Each data set was selected according to one of the following groups:

$\checkmark$ "small number of features - small number of copies" (SS): data sets with a number of features less than 13 and a number of copies less than 1000;

- "small number of features - large number of copies" (SL): data sets with a number of features less than 13 and a number of copies more than or equal to 1000 ;

$\downarrow$ "large number of features - small number of copies" (LS): data sets with a number of features more than or equal to 13 and a number of copies less than 1000;

$\checkmark$ "large number of features - large number of copies" (LL): data sets with a number of features more than or equal to 13 and a number of copies more than or equal to 1000 .

The experiments have been implemented in accordance with the principle of cross-validation, which intends to separate the data set into training and test data. As per the described principle, each data set is represented by a group of files being test and training samples. Accordingly, during the experiments the classifier was constructed on training samples, following which the accuracy was evaluated on test samples. The total value of accuracy on the test and training data was determined by calculation of the average value.

For all data sets, triangular membership functions were used. As the algorithm parameters, the following parameters were selected: the number of species is 30; climb process iterations are 5; jump iterations are 5 ; roll-over iterations are 15 , the watch-jump process interval is 0.5 , boundaries of the somersault process are 0.5 and 0.5 for the left and right boundaries, respectively.

Table 2 shows the average results of the experimental study of the monkey algorithm when constructing fuzzy rule-based classifiers on a full feature set, as well as the results of analog algorithms "D-MOFARC" and "FARC-HD" [11]; where \# R is the number of rules, $\# \mathrm{~L}$ is the percentage of correct classification on the training sample, \#T is the percentage of correct classification on the test sample; the best results are in semibold type.
To assess the statistical significance of differences in accuracy and the number of rules of classifiers formed by a combination of algorithms EC+MA and analog classifiers, a criterion of pairwise comparisons Wilcoxon-Mann-Whitney was used.

Comparative analysis made it possible to draw the following conclusions:

1) The Wilcoxon-Mann-Whitney test indicates a significant difference between the number of rules in the classifiers based on $\mathrm{EC}+\mathrm{MA}$ and analog classifiers (p-value $<5 \mathrm{E}-8$ );

2) The Wilcoxon-Mann-Whitney test indicates the absence of a significant difference between the accuracy of classification in the compared classifiers.

These findings lead us to the following conclusion: with statistically undistinguished accuracy of the compared classifiers, the classifiers optimized by a combination of algorithms $\mathrm{EC}+\mathrm{MA}$ are preferable due to the smaller number of rules, and that ultimately points to their possible higher interpretability.

An important issue of algorithm comparison based on their computational complexity remained beyond the framework of article, because the articles which provide the results of previous studies have no detailed description of the algorithms and do not present the experiment results by which we can judge the computational complexity of these approaches.

\section{Conclusion}

This paper addresses methods of building fuzzy rulebased classifiers. The classifier structure was formed by an algorithm for generating rule base by extreme features. The monkey algorithm was applied to optimize the classifier parameters.

The efficiency of the fuzzy rule-based classifiers configured by the listed algorithms was checked on a number of data sets from the KEEL repository. The classifications obtained have a good learning capability (a high percentage of correct classification on training samples) and as much as good predictive capability (a high percentage of correct classification on test samples).

The number of rules used by the classifiers built with the use of the developed algorithms is much less than the number of rules in the analog classifiers with a comparable classification accuracy; that points to a possibly higher interpretability of classifiers built on the basis of combination EC+MA. 


\section{References}

1. Garcia-Galan S., Prado R.P., Exposito M.J.E. (2015) Rules discovery in fuzzy classifier systems with PSO for scheduling in grid computational infrastructures. Applied Soft Computing, no. 29, pp. 424-435.

2. Gorzalczany M.B., Rudzinski F. (2016) A multi-objective genetic optimization for fast, fuzzy rule-based credit classification with balanced accuracy and interpretability. Applied Soft Computing, no. 40, pp. 206-220.

3. Laha A. (2007) Building contextual classifiers by integrating fuzzy rule based classification technique and k-nn method for credit scoring. Advanced Engineering Informatics, no. 21, pp. 281-291.

4. Zhao R., Chai C., Zhou X. (2012) Using evolving fuzzy classifiers to classify consumers with different model architectures. Physics Procedia, no. 25, pp. 1627-1636.

5. Setnes M., Kaymak U. (2001) Fuzzy modeling of client preference from large data sets: An application to target selection in direct marketing. IEEE Transactions on Fuzzy Systems, no. 9, pp. 153-163.

6. Meier A., Werro N. (2007) A fuzzy classification model for online customers. Informatica, no. 31, pp. 175-182.

7. Gorbunov I.V., Hodashinsky I.A. (2015) Metody postroeniya trekhkriterial'nykh pareto-optimal'nykh nechetkikh klassifikatorov [Methods of buildings Pareto-optimal fuzzy classifiers]. Artificial Intelligence and Decision Making, no. 2, pp. $75-87$ (in Russian).

8. Scherer R. (2012) Multiple fuzzy classification systems. Studies in Fuzziness and Soft Computing, vol. 288. Berlin: Springer-Verlag.

9. Hodashinsky I.A. (2012) Identifikatsiya nechetkikh sistem na baze algoritma imitatsii otzhiga i metodov, osnovannykh na proizvodnykh [Simulated annealing and methods based on derivatives for fuzzy system identification]. Information Technologies, no. 3, pp. 14-20 (in Russian).

10. Antonelli M., Ducange P., Marcelloni F. (2014) An experimental study on evolutionary fuzzy classifers designed for managing imbalanced datasets. Neurocomputing, no. 146, pp. 125-136.

11. Fazzolari F., Alcala R., Herrera F. (2014) A multi-objective evolutionary method for learning granularities based on fuzzy discretization to improve the accuracy-complexity trade-off of fuzzy rule-based classification systems: D-MOFARC algorithm. Applied Soft Computing, no. 24 , pp. $470-481$.

12. Hodashinsky I.A., Gorbunov I.V. (2012) Optimizatsiya parametrov nechetkikh sistem na osnove modifitsirovannogo algoritma pchelinoy kolonii [Optimization of fuzzy systems parameters using the modified bee colonies algorithm]. Mechatronics, Automation, Control, no. 10, pp. 15-20 (in Russian).

13. Hodashinsky I.A., Dudin P.A. (2011) Identifikatsiya nechetkikh sistem na osnove pryamogo algoritma murav'inoy kolonii [Fuzzy systems identification based on direct ant colony algorithm]. Artificial Intelligence and Decision Making, no. 3, pp. 26-33 (in Russian).

14. Hodashinsky I.A., Dudin P.A. (2008) Parametricheskaya identifikatsiya nechetkikh modeley na osnove gibridnogo algoritma murav'inoy kolonii [Parametric fuzzy model identification based on a hybrid ant colony algorithm]. Avtometriya, no. 5 (44), pp. $24-35$ (in Russian).

15. Zhao R., Tang W. (2008) Monkey algorithm for global numerical optimization. Journal of Uncertain Systems, no. 2, pp. $165-176$.

16. Zheng L. (2013) An improved monkey algorithm with dynamic adaptation. Applied Mathematics and Computation, no. 222, pp. 645-657.

\section{Построение нечеткого классификатора на основе алгоритма обезьян ${ }^{2}$}

\section{И.А. Ходашинский}

доктор технических наук

профессор кафедры комплексной информационной безопасности электронно-вычислительных систем

Томский государственный университет систем управления и радиоэлектроники (ТУСУР)

Адрес: 634050, г. Томск, пр-т Ленина, д. 40

E-mail:hodashn@rambler.ru

\section{C.С. Самсонов}

студент кафедры комплексной информационной безопасности электронно-вычислительных систем

Томский государственный университет систем управления и радиоэлектроники (ТУСУР)

Адрес: 634050, г. Томск, пр-т Ленина, д. 40

E-mail: samsonicx@mail.ru

\footnotetext{
${ }^{2}$ Исследование выполнено в рамках базовой части государственного задания министерства образования и науки Российской Федерации на 2017-2019 гг. № 8.9628.2017/БЧ
} 


\section{Аннотация}

В статье представлен подход к построению классификаторов на основе нечетких правил. Нечеткий классификатор состоит из ЕСЛИ-ТО правил с нечеткими антецедентами (ЕСЛИ-часть) и метками класса в консеквентах (ТО-часть). Антецедентные части правил разбивают входное пространство признаков на множество нечетких областей, а консеквенты задают выход классификатора, помечая эти области меткой класса. Выделены два основных этапа построения классификатора: генерация базы нечетких правил и оптимизация параметров антецедентов правил. Формирование структуры классификатора выполнялась алгоритмом генерации базы правил по экстремальным значениям признаков, найденным в обучающей выборке. Особенность данного алгоритма заключается в том, что он генерирует по одному классифицирующему правилу на каждый класс. База правил, сформированная данным алгоритмом, имеет минимально возможный размер при классификации заданного набора данных. Оптимизация параметров антецедентов нечетких правил выполнена с помощью адаптированного для этих целей алгоритма обезьян, основанного на наблюдениях за передвижением обезьян в горной местности. В процессе работы алгоритма выполняются три оператора: движение вверх, локальный прыжок и глобальный прыжок. Одним из достоинств алгоритма при решении задач оптимизации большой размерности является вычисление псевдо-градиента целевой функции, причем вне зависимости от размерности на каждой итерации выполнения алгоритма требуется вычислить только два значения целевой функции.

Эффективность нечетких классификаторов, построенных с помощью предложенных алгоритмов, проверена на реальных данных из хранилища KEEL. Проведен сравнительный анализ с известными алгоритмами-аналогами «D-MOFARC» и «FARC-HD». Число правил, используемых классификаторами, построенными с помощью разработанных алгоритмов, значительно меньше числа правил в классификатораханалогах при сопоставимой точности классификации, что указывает на возможно более высокую интерпретируемость классификаторов, построенных с использованием предлагаемого подхода.

Ключевые слова: нечеткий классификатор, оптимизация параметров, алгоритм обезьян, формирование базы правил.

Цитирование: Hodashinsky I.A., Samsonov S.S. Design of fuzzy rule based classifier using the monkey algorithm // Business Informatics. 2017. No. 1 (39). P. 61-67. DOI: 10.17323/1998-0663.2017.1.61.67.

\section{Литература}

1. Garcia-Galan S., Prado R.P., Exposito M.J.E. Rules discovery in fuzzy classifier systems with PSO for scheduling in grid computational infrastructures // Applied Soft Computing. 2015. No. 29. P. 424-435.

2. Gorzalczany M.B., Rudzinski F. A multi-objective genetic optimization for fast, fuzzy rule-based credit classification with balanced accuracy and interpretability // Applied Soft Computing. 2016. No. 40. P. 206-220.

3. Laha A. Building contextual classifiers by integrating fuzzy rule based classification technique and k-nn method for credit scoring // Advanced Engineering Informatics. 2007. No. 21. P. 281-291.

4. Zhao R., Chai C., Zhou X. Using evolving fuzzy classifiers to classify consumers with different model architectures // Physics Procedia. 2012. No. 25. P. $1627-1636$.

5. Setnes M., Kaymak U. Fuzzy modeling of client preference from large data sets: An application to target selection in direct marketing // IEEE Transactions on Fuzzy Systems. 2001. No. 9. P. 153-163.

6. Meier A., Werro N. A fuzzy classification model for online customers // Informatica. 2007. No. 31. P. $175-182$.

7. Горбунов И.В., Ходашинский И.А. Методы построения трехкритериальных парето-оптимальных нечетких классификаторов // Искусственный интеллект и принятие решений. 2015. № 2. С. 75-87.

8. Scherer R. Multiple fuzzy classification systems // Studies in Fuzziness and Soft Computing. Vol. 288. Berlin: Springer-Verlag, 2012.

9. Ходашинский И.А. Идентификация нечетких систем на базе алгоритма имитации отжига и методов, основанных на производных // Информационные технологии. 2012. № 3. С. 14-20.

10. Antonelli M., Ducange P., Marcelloni F. An experimental study on evolutionary fuzzy classi ers designed for managing imbalanced datasets // Neurocomputing. 2014. No. 146. P. 125-136.

11. Fazzolari F., Alcala R., Herrera F. A multi-objective evolutionary method for learning granularities based on fuzzy discretization to improve the accuracy-complexity trade-off of fuzzy rule-based classification systems: D-MOFARC algorithm // Applied Soft Computing. 2014. No. 24. P. 470-481.

12. Ходашинский И.А., Горбунов И.В. Оптимизация параметров нечетких систем на основе модифицированного алгоритма пчелиной колонии // Мехатроника, автоматизация, управление. 2012. № 10. С. 15-20.

13. Ходашинский И.А., Дудин П.А. Идентификация нечетких систем на основе прямого алгоритма муравьиной колонии // Искусственный интеллект и принятие решений. 2011. № 3. С. 26-33.

14. Ходашинский И.А., Дудин П.А. Параметрическая идентификация нечетких моделей на основе гибридного алгоритма муравьиной колонии // Автометрия. 2008. № 5 (44). С. 24-35.

15. Zhao R., Tang W. Monkey algorithm for global numerical optimization // Journal of Uncertain Systems. 2008. No. 2. P. 165-176.

16. Zheng L. An improved monkey algorithm with dynamic adaptation // Applied Mathematics and Computation. 2013. No. 222. P. 645-657. 


\title{
An adaptive neuro-fuzzy inference system for assessment of risks to an organization's information security ${ }^{1}$
}

\author{
Sergey A. Glushenko \\ Senior Lecturer, Department of Information Systems and Applied Computer Science \\ Rostov State University of Economics \\ Address: 69, Bolshaya Sadovaya Street, Rostov-on-Don, 344002, Russian Federation \\ E-mail:gs-gears@yandex.ru
}

Abstract

This article explains the importance of applying risk assessment in the implementation of information security systems. It is considered the most common risk assessment procedure and entails application of fuzzy logic theory for this purpose. The paper describes the proposed fuzzy production model (FPM), which defines seven input linguistic variables describing risk factors, four output linguistic variables that characterize different areas of information security risks, as well as four base rules.

It is noted that the FPM is the first approach to the subject area and requires optimization to minimize the model's output errors. The most common methods of optimization of fuzzy models parameters are examined, and the advantages of applying methods based on neuro-fuzzy networks (NFN) are justified.

The article describes the process of converting fuzzy model elements, such as unit fuzzification, rule base unit and unit defuzzification, into fragments of the neural network. The result of this process is a neuro-fuzzy network corresponding to the fuzzy model.

Formation of the developed NFN is based on an adaptive neuro-fuzzy inference system (ANFIS), using the specialized Neuro-Fuzzy Designer package of MATLAB software. The model was trained by a hybrid method which represents a combination of the methods of least squares and backpropagation. The result of this process is optimization (setting) the parameters of membership functions of input linguistic variables.

Application of neuro-fuzzy modeling made it possible to obtain a more appropriate fuzzy production model which is able to conduct linguistic analysis of the risks of an organization's information security. The information obtained with its help allows IT managers to determine risk priorities and to develop effective action plans to reduce the impact of the most dangerous threats.

Key words: risk, information security, linguistic variable, membership function, neuro-fuzzy network, adaptive neuro-fuzzy inference system, neuro-fuzzy designer.

Citation: Glushenko S.A. (2017) An adaptive neuro-fuzzy inference system for assessment of risks to an organization's information security. Business Informatics, no. 1 (39), pp. 68-77. DOI: 10.17323/1998-0663.2017.1.68.77.

\footnotetext{
${ }^{1}$ This research has been carried out with financial support of RFBR within the framework of scientific project No. 16-31-00285 "Fuzzy logic methods and models in risk management decision support systems"
} 


\section{Introduction}

$\mathrm{T}$ The introduction of information technologies and computing facilities in the production and management of modern enterprises provides an effective tool to increase labor productivity. However, the enterprise IT-infrastructure often takes an unstructured form, which leads to an uncontrolled growth of information security (IS) vulnerabilities and risks to the enterprise as a whole.

Information security is an "information and supporting infrastructure protection against accidental or intentional effects of a natural or artificial character, which can cause unacceptable harm" [1].

Paper [2] analyzes the most common methods of IS risk assessment - NIST [3] and CRAMM [4], describes their disadvantages and proposes to use fuzzy logics for these purposes. The proposed fuzzy production model (FPM) includes seven input linguistic variables
(Table 1) describing risk factors, four output linguistic variables (Table 2), characterizing risks of various areas of information security, as well as four rules bases (Table 3) $[2,5]$.

When forming the input linguistic variables, the following term sets can be used, which determine the levels of factors [6]:

$-\mathrm{T} 2=\{\operatorname{Low}(\mathrm{L}) ; \operatorname{High}(\mathrm{H})\}$

- T3 $=\{$ Low (L); Medium (M); High (H) $\}$;

- T4 $=\{$ Very Low $(\operatorname{VrL}) ;$ Low (L); Medium (M); High $(\mathrm{H})\}$;

- T5 $=\{$ Very Low $(\operatorname{VrL}) ;$ Low (L); Medium (M); High $(\mathrm{H})$; Very High $(\mathrm{VrH})\}$.

When developing output linguistic variables, the following term sets can be used which determine risk factors [6]:

Table 1.

Risk factors of the information security of organization

\begin{tabular}{|c|c|c|}
\hline Designation & Name of linguistic variable & Type of term set and interpretation of levels of factors \\
\hline$x_{1}$ & Software/hardware protection & $\begin{array}{l}\text { T3. } \mathrm{L} \text { - satisfactory to ensure the initial security level; } \\
\mathrm{M} \text { - sufficient for basic information security; } \\
\mathrm{H} \text { - completely complies with the information confidentiality level }\end{array}$ \\
\hline$x_{2}$ & Organizational protection & $\begin{array}{l}\text { T3. } \mathrm{L} \text { - deficient planning and lack of monitoring of vulnerabilities; } \\
\mathrm{M} \text { - planning and monitoring of vulnerabilities are conducted irregularly; } \\
\mathrm{H} \text { - timely planning and monitoring of vulnerabilities }\end{array}$ \\
\hline$x_{3}$ & Legal protection & $\begin{array}{l}\text { T3. } \mathrm{L} \text { - fragmentary and incomplete documentation; } \\
\mathrm{M} \text { - documentation is available, but short on details; } \\
\mathrm{H} \text { - documentation is complete and synchronized }\end{array}$ \\
\hline$x_{4}$ & Motivation of a threats source (TS) & $\begin{array}{l}\text { T5. VrL - none; } \\
\mathrm{L} \text { - rare manifestation of interest; } \\
\mathrm{M} \text { - may well provoke interest; } \\
\mathrm{H} \text { - most likely will be interested in it; } \\
\mathrm{VrH} \text { - necessarily will take interest in it }\end{array}$ \\
\hline$x_{5}$ & Possibilities of a threats source (TS) & $\begin{array}{l}\text { T5. VrL - none; } \\
\mathrm{L} \text {-insignificant level of TS infrastructure; } \\
\mathrm{M} \text { - medium level of infrastructure; } \\
\mathrm{H} \text { - rather high level of infrastructure; } \\
\text { VrH - TS has significant possibilities }\end{array}$ \\
\hline$x_{6}$ & $\begin{array}{l}\text { Market value of an information resource } \\
\text { (IR) }\end{array}$ & $\begin{array}{l}\text { T5. VrL - clear information; } \\
\mathrm{L}-\mathrm{IR} \text { is of little value; } \\
\mathrm{M} \text { - IR is commercially confidential; } \\
\mathrm{H} \text { - highly confidential data; } \\
\text { VrH - catastrophic value for the organization (strategic planning) }\end{array}$ \\
\hline$x_{7}$ & $\begin{array}{l}\text { Volume of information resource data } \\
\text { (IR) of organization }\end{array}$ & $\begin{array}{l}\text { T5. VrL - very small part; } \\
\mathrm{L} \text { - minor part; } \\
\mathrm{M} \text { - half of IR; } \\
\mathrm{H} \text { - major part; } \\
\text { VrH - full volume of IR }\end{array}$ \\
\hline
\end{tabular}


Risk factors of information security of an organization

\begin{tabular}{c|l|l}
\hline Designation & \multicolumn{1}{|c|}{ Name of linguistic variable } & Remark \\
\hline$y_{1}$ & Risk of effective protection reduction & $\begin{array}{l}\text { Characterizes the capability to reduce/increase the effective protection in relation } \\
\text { to the required effectiveness for a particular enterprise }\end{array}$ \\
\hline$y_{2}$ & Risk of potential threats & Characterizes the possibility of potential threats to an enterprise \\
\hline$y_{3}$ & Risk of material damage & $\begin{array}{l}\text { Characterizes the possibility of material damage to an enterprise when the organization's } \\
\text { information security parameters are violated }\end{array}$ \\
\hline$y_{4}$ & Risk to an organization's IS & Integrated risk describing the enterprise's assurance level of information security \\
\hline
\end{tabular}

Table 3.

Fuzzy production rules of a model (fragment)

Rules base R1

\begin{tabular}{|c|c|c|}
\hline $\mathrm{R} 1.1$ & $\begin{aligned}\left(x_{1}=\mathrm{L} \wedge x_{2}=\right. & \left.\mathrm{L} \wedge x_{3}=\mathrm{L}\right) \vee\left(x_{1}=\mathrm{M} \wedge x_{2}=\mathrm{L} \wedge x_{3}=\mathrm{L}\right) \vee \\
& \left(x_{1}=\mathrm{L} \wedge x_{2}=\mathrm{M} \wedge x_{3}=\mathrm{L}\right)\end{aligned}$ & $y_{1}=\operatorname{VrHER}$ \\
\hline $\mathrm{R} 1.2$ & $\begin{array}{c}\left(x_{1}=\mathrm{H} \wedge x_{2}=\mathrm{L} \wedge x_{3}=\mathrm{L}\right) \vee\left(x_{1}=\mathrm{M} \wedge x_{2}=\mathrm{M} \wedge x_{3}=\mathrm{L}\right) \vee \\
\left(x_{1}=\mathrm{L} \wedge x_{2}=\mathrm{H} \wedge x_{3}=\mathrm{L}\right) \vee\left(x_{1}=\mathrm{M} \wedge x_{2}=\mathrm{H} \wedge x_{3}=\mathrm{L}\right) \vee \\
\left(x_{1}=\mathrm{L} \wedge x_{2}=\mathrm{L} \wedge x_{3}=\mathrm{M}\right) \vee\left(x_{1}=\mathrm{L} \wedge x_{2}=\mathrm{M} \wedge x_{3}=\mathrm{M}\right) \vee \\
\left(x_{1}=\mathrm{L} \wedge x_{2}=\mathrm{H} \wedge x_{3}=\mathrm{M}\right) \vee\left(x_{1}=\mathrm{L} \wedge x_{2}=\mathrm{L} \wedge x_{3}=\mathrm{H}\right)\end{array}$ & $y_{1}=\mathrm{HER}$ \\
\hline $\mathrm{R} 1.3$ & $\begin{array}{c}\left(x_{1}=\mathrm{H} \wedge x_{2}=\mathrm{M} \wedge x_{3}=\mathrm{L}\right) \vee\left(x_{1}=\mathrm{H} \wedge x_{2}=\mathrm{H} \wedge x_{3}=\mathrm{L}\right) \vee \\
\left(x_{1}=\mathrm{M} \wedge x_{2}=\mathrm{L} \wedge x_{3}=\mathrm{M}\right) \vee\left(x_{1}=\mathrm{H} \wedge x_{2}=\mathrm{L} \wedge x_{3}=\mathrm{M}\right) \vee \\
\left(x_{1}=\mathrm{M} \wedge x_{2}=\mathrm{M} \wedge x_{3}=\mathrm{M}\right) \vee\left(x_{1}=\mathrm{M} \wedge x_{2}=\mathrm{H} \wedge x_{3}=\mathrm{M}\right) \vee \\
\left(x_{1}=\mathrm{M} \wedge x_{2}=\mathrm{L} \wedge x_{3}=\mathrm{H}\right) \vee\left(x_{1}=\mathrm{L} \wedge x_{2}=\mathrm{M} \wedge x_{3}=\mathrm{H}\right) \vee \\
\left(x_{1}=\mathrm{M} \wedge x_{2}=\mathrm{M} \wedge x_{3}=\mathrm{H}\right) \vee\left(x_{1}=\mathrm{L} \wedge x_{2}=\mathrm{H} \wedge x_{3}=\mathrm{H}\right)\end{array}$ & $y_{1}=\mathrm{MER}$ \\
\hline $\mathrm{R} 1.4$ & $\begin{array}{c}\left(x_{1}=\mathrm{H} \wedge x_{2}=\mathrm{M} \wedge x_{3}=\mathrm{M}\right) \vee\left(x_{1}=\mathrm{H} \wedge x_{2}=\mathrm{H} \wedge x_{3}=\mathrm{M}\right) \vee \\
\left(x_{1}=\mathrm{H} \wedge x_{2}=\mathrm{L} \wedge x_{3}=\mathrm{H}\right) \vee\left(x_{1}=\mathrm{H} \wedge x_{2}=\mathrm{M} \wedge x_{3}=\mathrm{H}\right) \vee \\
\left(x_{1}=\mathrm{M} \wedge x_{2}=\mathrm{H} \wedge x_{3}=\mathrm{H}\right)\end{array}$ & $y_{1}=\mathrm{LER}$ \\
\hline $\mathrm{R} 1.5$ & $x_{1}=\mathrm{H} \wedge x_{2}=\mathrm{H} \wedge x_{3}=\mathrm{H}$ & $y_{1}=\mathrm{VrLER}$ \\
\hline
\end{tabular}

$-\mathrm{T} 1=\{$ Low evidence of risk (LER); Medium evidence of risk (MER); High evidence of risk (HER)\};

$-\mathrm{T} 2=\{$ Very low evidence of risk $($ VrLER); Low evidence of risk (LER); Medium evidence of risk (MER); High evidence of risk (HER); Very high evidence of risk (VrHER)\}.

In order to build a fuzzy model, it is necessary to de- termine all its elements: rules base, number and type of membership functions for each variable model, parameters of membership functions, logical operators, etc.

The structure of the fuzzy production model for assessing risk to an organization's information security is provided in Figure 1. 


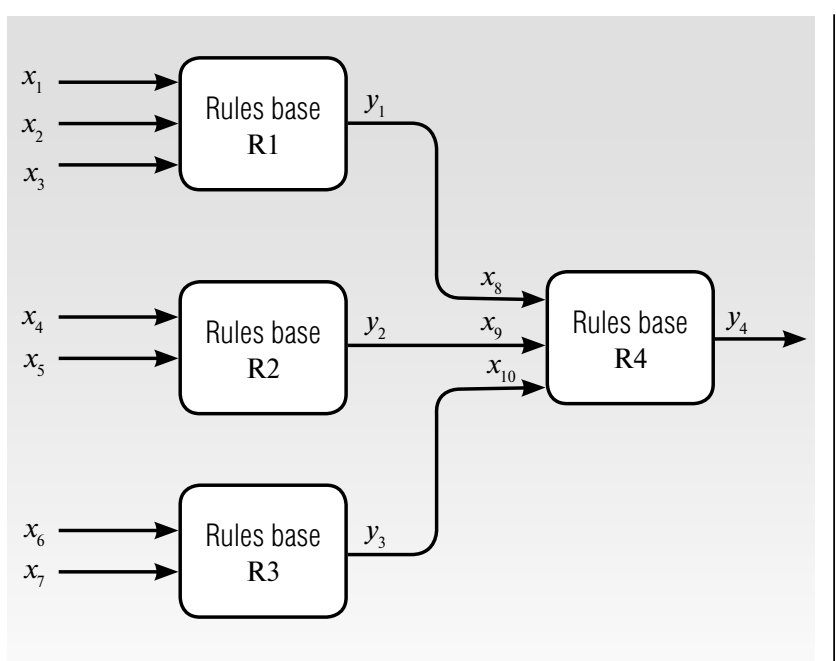

Fig. 1. Structure of fuzzy productive model

\section{Statement of the problem}

The developed model is based on expert knowledge about the modeled information security system (ISS) $[2,5,7]$. The system information was obtained with the involvement of an expert in the domain area, with the information obtained converted in a fuzzy model. This method is efficient if the expert has a perfect knowledge of the ISS. In practical work, the expert's knowledge is often insufficiently complete and accurate, and sometimes even contains contradictions. Therefore, the model should be based on objective system information, which can be presented by data from measuring the system input and output values [8].

These circumstances predetermine the relevance of development of the fuzzy self-tuning model for ISS risk assessment. The fuzzy model setting should primarily mean a process of determining parameters of the membership functions of input and output linguistic variables which minimize errors of the model outputs relative to the observed prototype system.

For model setting, namely, the optimization of its parameters, the following methods are most often used [9]:

$\downarrow$ methods based on using neuro-fuzzy networks;

$\checkmark$ searching methods;

$\downarrow$ clustering-based methods.

The first group methods are associated with the conversion of a fuzzy model in a neuro-fuzzy network (NFN) and application of network training methods based on measurements of input and output system data for settings of the model network.

The second group methods are direct search methods for optimal parameters of the fuzzy model. The search process can be both ordered and unordered (trial-anderror method). The most commonly used ordered search method is a method based on the use of genetic algorithms.

Clustering-based methods combine model parameters setting and its structuring. They are used for building fuzzy self-organizing models which have control over their essential input parameters, define an optimal number of fuzzy sets for input and output linguistic variables, and establish the form and number of rules.

Currently, the most studied methods are the first group methods. They make it possible to [10]:

optimize (set) parameters of the membership functions of linguistic parameters based on measurements of input and output dependences of the actual system;

$\diamond$ correct fuzzy models which are not developed adequately enough by experts;

extend the expert-developed fuzzy models to the area of the studied model, where expert knowledge is limited.

The listed peculiarities explain the applicability of methods based on the use of neuro-fuzzy networks for setting a fuzzy model for assessing risk to an organization's information security.

\section{Conversion of fuzzy model to neuro-fuzzy network}

A conversion of fuzzification block elements is provided in Figure 2, which depicts a conversion of the piecewise linear membership functions to a fragment of the neural network.

To set parameters $a_{i}$ of the membership functions in the course of network training, it is necessary to calculate derivatives of output values of the fuzzification block using appropriate parameters.

Block fuzzification results in calculated values of a degree of membership of input values by fuzzy set $A_{i j}$, each of which represents a linguistic range of definition.

The conversion of block elements of the rules base predicts presentation of the rule condition in the form of a neural network fragment. In this case, operations "AND" and "OR" can be performed using T- and Snorms and standards, or through other operators.

The input parameters of the defuzzification block are activation degrees $\mu_{B_{l}}(y)$ of fuzzy sets $B_{l}$ at the model output. The center-of-gravity method is used for their conversion to a distinct number. 


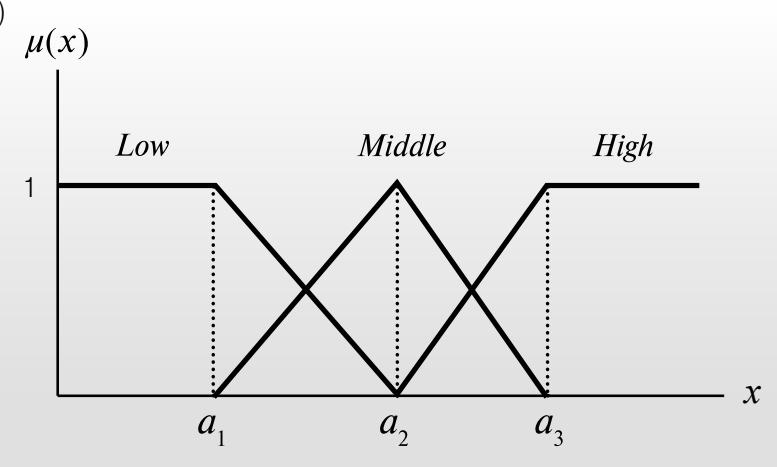

b)

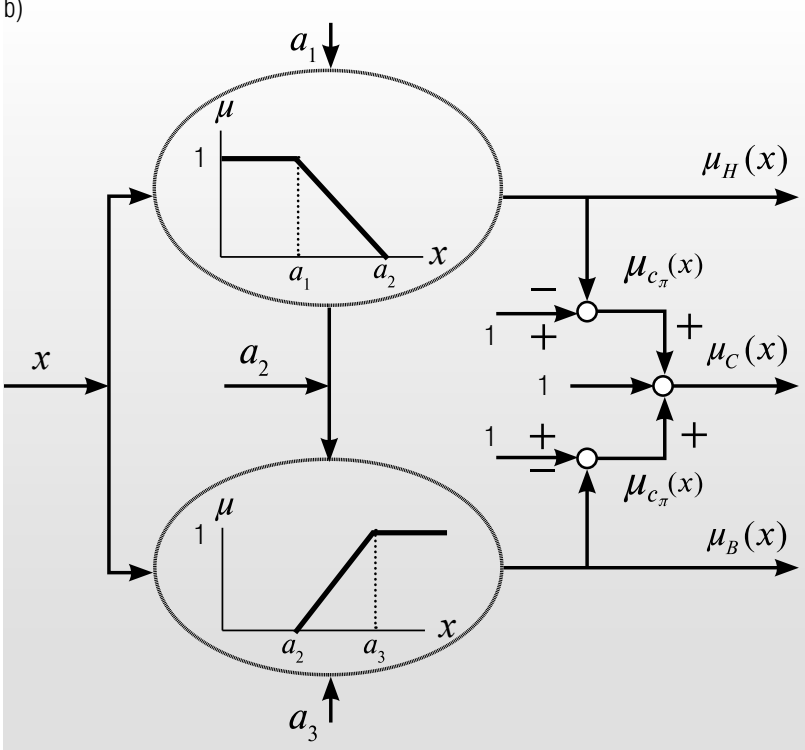

Fig. 2. Conversion of piecewise linear membership functions (a) to neural network fragments (b)

As a result, the neuro-fuzzy network corresponding to the fuzzy model in Table 3 will have the structure given in Figure 3.

\section{Application of Neuro-Fuzzy Designer package for building the NFN}

The developed NFN is built based on the adaptive neuro-fuzzy inference system (ANFIS) [8, 9] through the Neuro-Fuzzy Designer package of MATLAB software [11]. ANFIS is a neural network with several inputs and one output, which in their turn are fuzzy linguistic variables. In this case, the terms of input and output linguistic variables are described by membership functions that are coherent with the developed fuzzy self-tuning model of the IS risk assessment.

In the fuzzification phase, the triangular membership functions (Figure 4) for term sets of input $\left(x_{1}, x_{2}, x_{3}\right)$ and output $\left(y_{1}\right)$ linguistic variables (LV) were specified:

$x_{1}-\mathrm{LV}$ "Software and hardware protection" ( $\mathrm{SwH}-$ $w P r t)$

$x_{2}$ - LV "Organizational protection" (OrgPrt);

$x_{3}$ - LV "Legal protection" ( LegPrt);

$y_{1}-\mathrm{LV}$ "Risk of effective protection reduction" (RiskPrt).

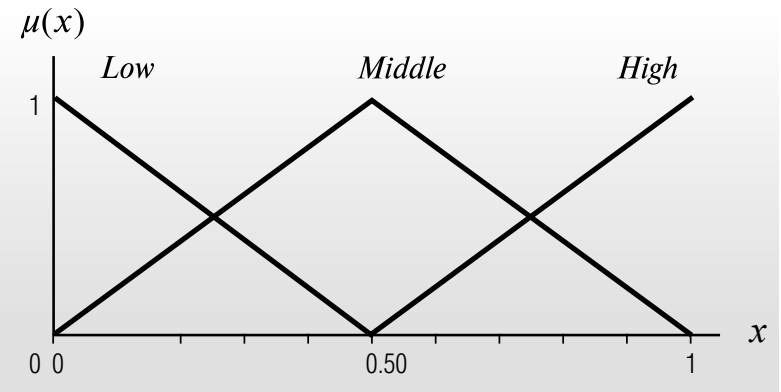

Fig. 4. Membership function for input variable SwHwPrt

The generated fuzzy inference system, which contains 27 rules of fuzzy products, is depicted in Figure 5.

NFN training was performed based on the training sample, which contained 200 sets representing a vector of values of factor levels having an impact on the risk, (input LV) and values of IS risk level (output LV). The data was obtained by generalizing the domain expert opinions using the Delphi method within the approach proposed in paper [12]. To generate training sets, the data received from the intrusion detection systems, antivirus programs, firewalls and other systems included in the ISS can be also used.

The Neuro-Fuzzy Designer package enables you to train using the method of backpropagation, the main purpose of which is to set up all multilayer structure layers by changing weights of intermediate layers, and the hybrid method, which is a combination of the method of least squares and the method of backpropagation. The results of applying NFN training methods for risk assessment of information security are provided in Table 4.

Table 4.

\section{Application of Training Methods for Neutron-Fuzzy Network}

\begin{tabular}{c|c|c}
\hline Training method & Error value & $\begin{array}{c}\text { Number } \\
\text { of stages }\end{array}$ \\
\hline Method of backpropagation & 0.0271 & 200 \\
\hline Hybrid method & 0.0108 & 28 \\
\hline
\end{tabular}

${ }^{2}$ Number of stages required for achieving a stated error value 


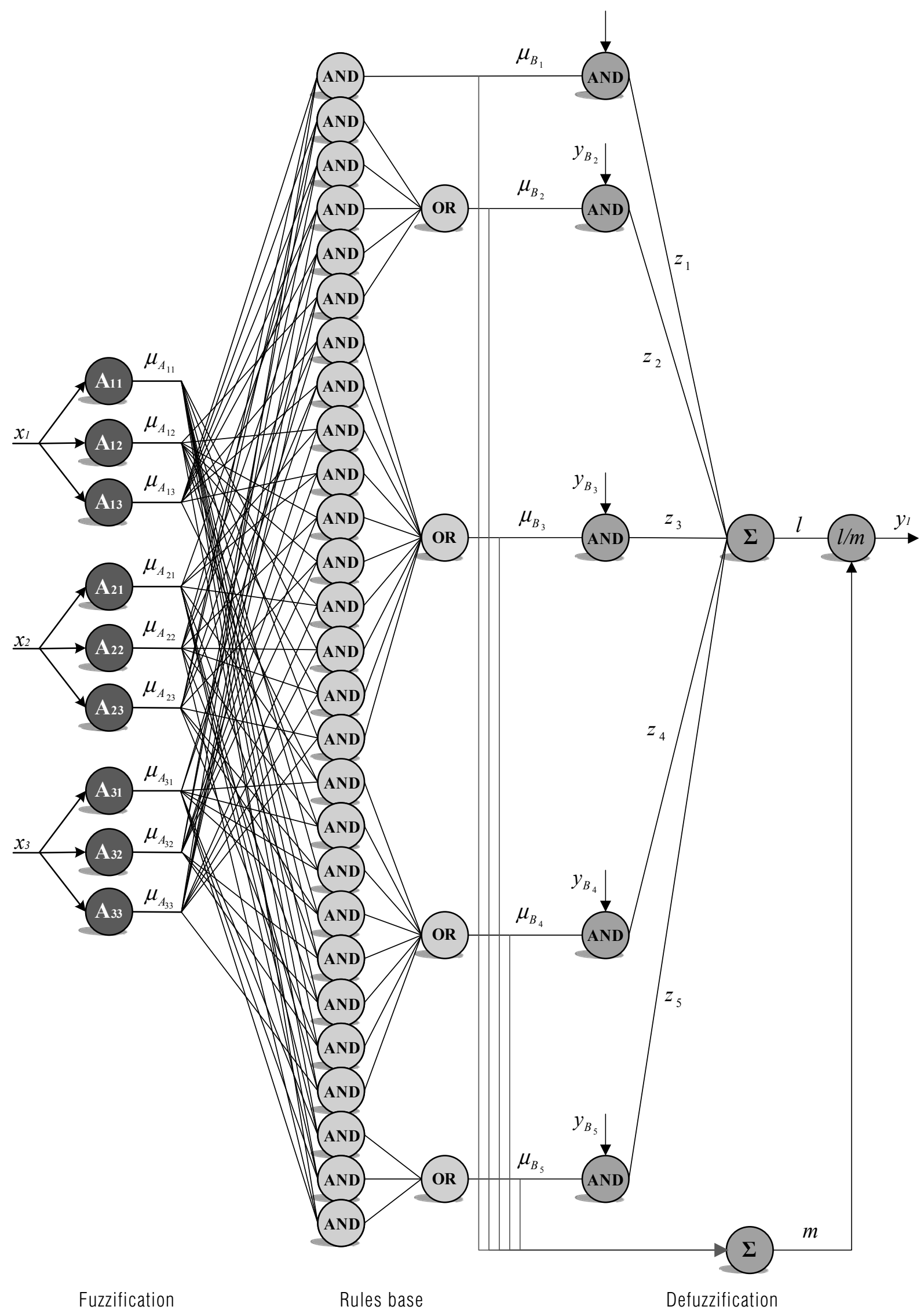

Fig. 3. Neuro-fuzzy network (fragment) 


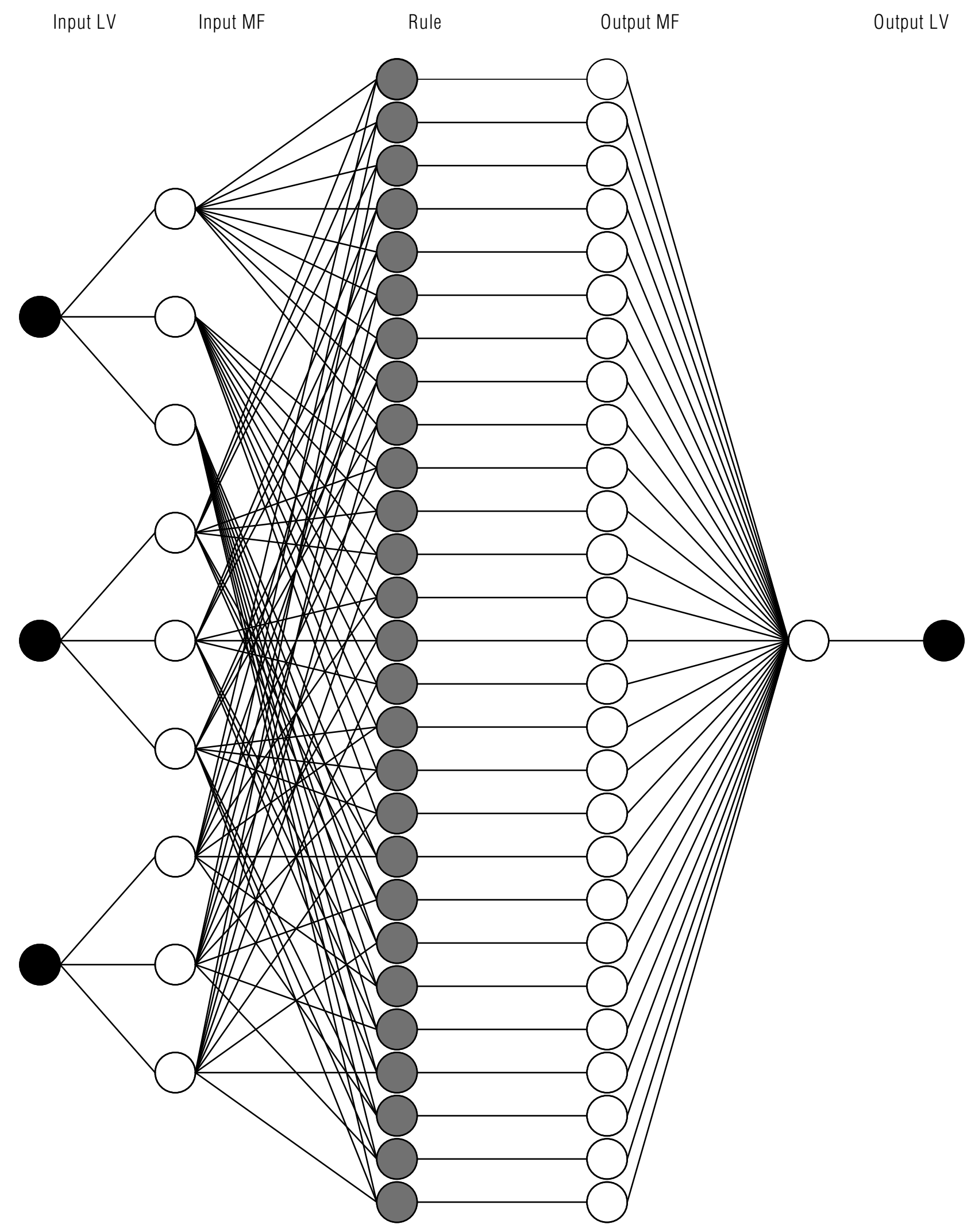

Fig. 5. Structure of fuzzy inference system 


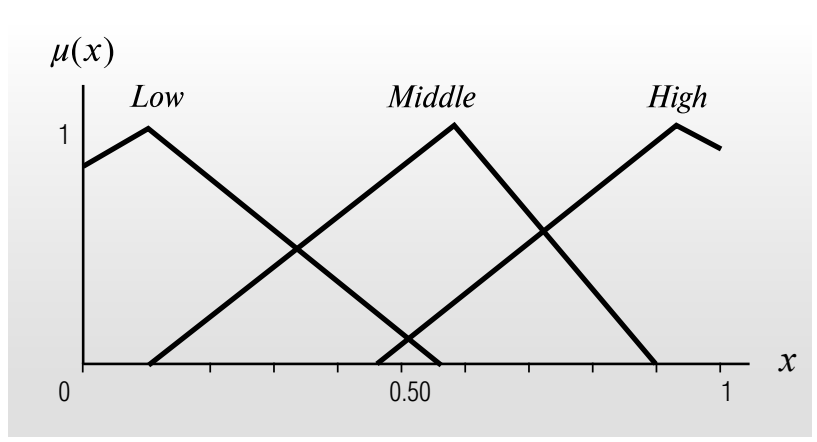

Fig. 6. Optimized membership functions

As the Table shows, the hybrid training method enables us to get better results of network errors value during a fewer number of stages. With this in mind, for configuring the membership function parameters the choice was made in favor of the hybrid method. Figure 6 depicts a result of optimization (setting) of membership function parameters of the linguistic variable $S w H w P r t$.

Figure 7 depicts a surface of the trained fuzzy model, which shows how output LV depends on two input LV; meanwhile, the third variable value is fixed.

The graphical view of dependence of output LV (RiscPrt - "Risk of effective protection reduction") on input LV ( $S w H w P r t$ - "Software and hardware protection" and OrgPrt - "Organizational protection") shows an expected increase of the value of risk of effective protection reduction of an organization with the decrease of the hardware-software protection and organizational protection [2].

Therefore, a smooth and monotone dependence diagram of the reduced "output surface" implies a good "quality" of the output mechanism and adequacy and consistency of the used inference rules.

The risk assessment mechanism based on NFN has broad capabilities. In particular, it can be adapted to the existing risk management models, and can be also modified taking into account the actual conditions of the organization's information security policy [7].

\section{Conclusion}

The fuzzy production model described in the introduction was the first approximation for the subject domain concerned and was to be set up. The developed fuzzy self-tuning model of the information security risk assessment enabled us to adjust parameters of the membership functions for linguistic variables for the information security systems under study and obtain a more adequate fuzzy production model.

The fuzzy self-tuning model we implemented enables us to perform continuous analysis of the information security risk, and the information obtained as a result of fuzzy modeling enables IT managers to identify risk priorities (from "very high" to "very low") and to develop effective action plans to reduce the impact of the most hazardous threats.

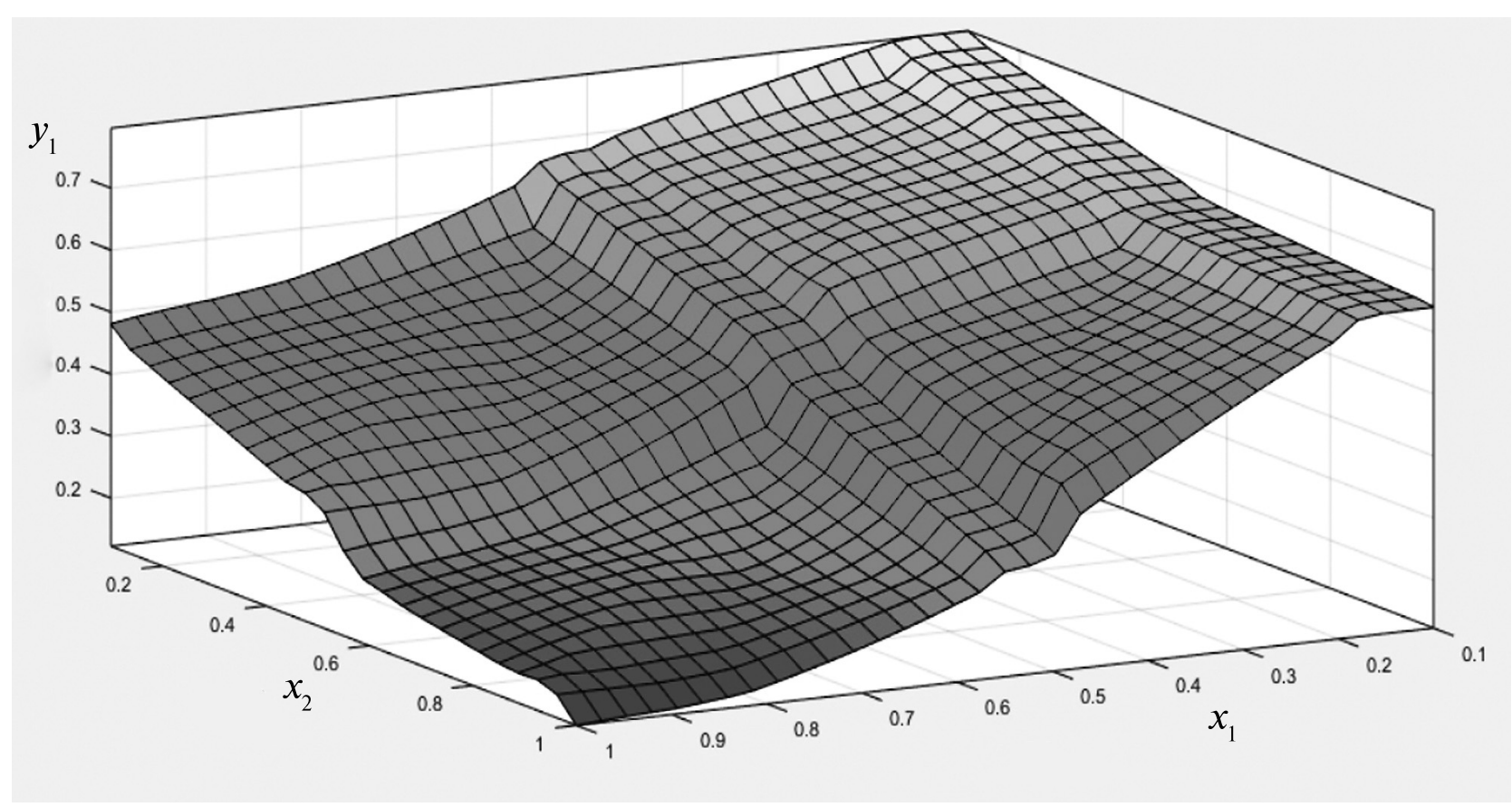

Fig. 7. Surface of the fuzzy model system 


\title{
References
}

1. State Technical Commission (2005) Informatsionnye tekhnologii. Osnovnye terminy i opredeleniya v oblasti tekhnicheskoy zashchity informatsii. Rekomendatsii po standartizatsii (R 50.1.053-2005) [Information technologies. Basic terms and definitions in scope of technical protection of information. Recommendations on standardization (P 50.1.053-2005)]. Moscow, State Technical Commission (in Russian).

2. Glushenko S.A. (2013) Primenenie sistemy MATLAB dlya otsenki riskov informatsionnoy bezopasnosti organizatsii [Risk assessment information security systems organization with MATLAB system]. Business Informatics, no. 4 (26), pp. 35-42 (in Russian).

3. National Institute of Standards and Technology (2002) Risk management guide for information technology systems. Special publication 800-30. Gaithersburg, MD: NIST.

4. Simonov S.V. (1999) Analiz riskov, upravlenie riskami [Risk analysis, risk management]. Jet Info, no. 1 (68), pp. 2-28 (in Russian).

5. Glushenko S.A. (2013) Nechetkaya produktsionnaya model' otsenki riskov informatsionnoy bezopasnosti organizatsii [Fuzzy production model for assessment of an organization's information security risks]. Economics and Law Issues, issue 11. Rostov-on-Don, RSUE (RINE), p. 147 (in Russian).

6. Dolzhenko A.I. (2009) Model' analiza riska potrebitel'skogo kachestva proektov ekonomicheskikh informatsionnykh sistem [Risk analysis model of consumer quality of economic information systems projects]. Bulletin of North-Caucasus State Technical University, vol. 18, no. 1, pp. 129-134 (in Russian).

7. Glushenko S.A., Dolzhenko A.I. (2015) Sistema podderzhki prinyatiya resheniy nechetkogo modelirovaniya riskov informatsionnoy bezopasnosti organizatsii [A decision support system for fuzzy modeling of an organization's information security risks]. Information Technologies, no. 1, pp. 68-74 (n Russian).

8. Borisov V.V., Kruglov A.S., Fedulov A.S. (2012) Nechetkie modeli i seti [Fuzzy models and networks]. Moscow: Hotline - Telecom (in Russian).

9. Piegat A. (2013) Nechetkoe modelirovanie i upravlenie [Fuzzy modeling and control]. Moscow: BINOM. Knowledge Laboratory (in Russian).

10. Rutkowska D., Pilinski M., Rutcowski L. (2006) Neyronnye seti, geneticheskie algoritmy i nechetkie sistemy [Neural networks, genetic algorithms and fuzzy systems]. Moscow: Hotline - Telecom (in Russian).

11. Leonenkov A.V. (2005) Nechetkoe modelirovanie v srede MATLAB i fuzzyTECH [Fuzzy modeling using MATLAB and fuzzyTECH]. Saint Petersburg: BHV-Petersburg (in Russian).

12. Khubaev G.N. (2011) Poluchenie gruppovoy ekspertnoy otsenki znacheniy pokazateley: poshagovaya protsedura i programmnoe obespechenie [Obtaining a group expert estimate of metrics values: a stepwise procedure and software]. Software and Systems, no. 2, pp. 13-16 (in Russian).

\section{Адаптивная нейро-нечеткая система оценки рисков информационной безопасности организации ${ }^{3}$}

\section{С.А. Глушенко}

кандидат экономических наук, старший преподаватель кафедры информационных систем и прикладной информатики Ростовский государственный экономический университет (РИНХ)

Адрес: 344002, г. Ростов-на-Дону, ул. Большая Садовая, д. 69

E-mail:gs-gears@yandex.ru

\begin{abstract}
Аннотация
В статье обосновывается важность применения оценки рисков при реализации системы обеспечения информационной безопасности. Рассматриваются наиболее распространенные методики оценки риска и предлагается использовать для этих целей теорию нечеткой логики. Описывается предложенная нечеткая продукционная модель (НПМ), в которой определены семь входных лингвистических переменных, характеризующих факторы риска, четыре выходных лингвистических переменных, характеризующих риски различных областей информационной безопасности, а также четыре базы правил.
\end{abstract}

\footnotetext{
${ }^{3}$ Исследование выполнено при финансовой поддержке РФФИ, в рамках научного проекта № 16-31-00285 «Методы и модели нечеткой логики в системах принятия решений управления рисками»
} 
Отмечается, что НПМ является первым приближением для рассматриваемой предметной области и требует оптимизации с целью минимизации ошибки выходов модели. Рассматриваются наиболее распространенные методы оптимизации параметров нечетких моделей и обосновываются преимущества применения методов, основанных на использовании нейро-нечетких сетей (ННС).

Описывается процесс преобразования элементов нечеткой модели, таких как блок фаззификации, блок базы правил и блок дефаззификации во фрагменты нейронной сети. Результатом данного процесса является нейро-нечеткая сеть, соответствующая нечеткой модели.

Построение разработанной ННС осуществляется на основе системы нейро-нечеткого вывода (adaptive neuro-fuzzy inference system, ANFIS) посредством применения специализированного пакета Neuro-Fuzzy Designer программного средства MATLAB. Обучение модели было выполнено гибридным методом, который представляет собой комбинацию методов наименьших квадратов и обратного распространения ошибки. Результатом данного процесса является оптимизация (настройка) параметров функций принадлежности входных лингвистических переменных

Использованный подход нейро-нечеткого моделирования позволил получить более адекватную нечеткую продукционную модель, которая позволяет проводить лингвистический анализ рисков информационной безопасности организации. Полученные с ее помощью сведения позволяют ИТ-менеджерам определять приоритеты рисков и разрабатывать эффективные планы мероприятий по снижению влияния наиболее опасных угроз.

Ключевые слова: риск, информационная безопасность, лингвистическая переменная, функция принадлежности, нейро-нечеткая сеть, система нейро-нечеткого вывода, дизайнер нейро-нечетких сетей.

Цитирование: Glushenko S.A. An adaptive neuro-fuzzy inference system for assessment of risks to an organization's information security // Business Informatics. 2017. No. 1 (39). P. 68-77. DOI: 10.17323/1998-0663.2017.1.68.77.

\section{Литература}

1. Информационные технологии. Основные термины и определения в области технической защиты информации. Рекомендации по стандартизации (Р 50.1.053-2005). М., 2005.

2. Глушенко С.А. Применение системы MATLAB для оценки рисков информационной безопасности организации // Бизнесинформатика. 2013. № 4 (26). С. 35-42.

3. Risk management guide for information technology systems. Special publication 800-30. Gaithersburg, MD: NIST, 2002.

4. Симонов С.В. Анализ рисков, управление рисками // Jet Info. 1999. № 1 (68). С. 2-28.

5. Глушенко С.А. Нечеткая продукционная модель оценки рисков информационной безопасности организации // Вопросы экономики и права: Сборник статей аспирантов и соискателей ученой степени кандидата наук. Выпуск 11. Ростов-на-Дону: РГЭУ (РИНХ), 2013. С. 147.

6. Долженко А.И. Модель анализа риска потребительского качества проектов экономических информационных систем // Вестник СевероКавказского государственного технического университета. 2009. Т. 18. № 1. С. 129-134.

7. Глушенко С.А., Долженко А.И. Система поддержки принятия решений нечеткого моделирования рисков информационной безопасности организации // Информационные технологии. 2015. № 1. С. 68-74.

8. Борисов В.В., Круглов А.С., Федулов А.С. Нечеткие модели и сети. 2-е изд. М.: Горячая линия - Телеком, 2012. 284 с.

9. Пегат А. Нечеткое моделирование и управление. 2-е изд. М.: БИНОМ. Лаборатория знаний, 2013.798 с.

10. Рутковская Д., Пилиньский М., Рутковский Л. Нейронные сети, генетические алгоритмы и нечеткие системы. М.: Горячая линия Телеком, 2006. $452 \mathrm{c}$.

11. Леоненков А.В. Нечеткое моделирование в среде MATLAB и fuzzyTЕСН. СПб: БХВ-Петербург, 2005. 736 с.

12. Хубаев Г.Н. Получение групповой экспертной оценки значений показателей: пошаговая процедура и программное обеспечение // Программные продукты и системы. 2011. № 2. С. 13-16. 


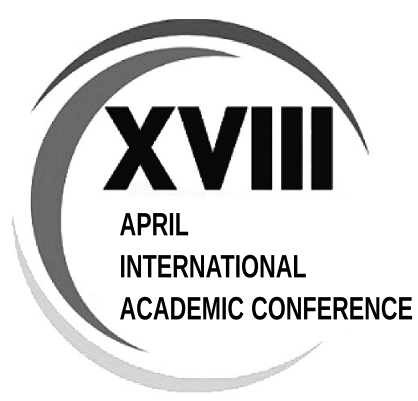

Moscow, 11-14 April 2017

Higher School of Economics has been hosting the annual April International Academic Conference on Economic and Social Development since 2000. Professor Evgeny Yasin, HSE's Academic Supervisor, is the Chair of the Conference Programme Committee.

The April Conference is the largest interdisciplinary event in social sciences in Russia, in terms of the number of its participants and attending representatives of the global academic community. At various times, Nobel Prize winners, as well as leading experts from the World Bank and Organisation for Economic Cooperation and Development $(\mathrm{OECD})$, have taken part in the Conference. This year, the Conference will bring together about 2000 participants, including 200 international experts.

Conference speakers are selected based on expert reviews of their academic papers by internationally renowned experts in respective disciplines. This year, 240 sessions that have successfully passed academic review shall be carried out.

Each session will feature three to four presentations focusing on current issues in economics, sociology, law, statistics, political science, management, public administration, finance and other fields related to the social sciences.

On top of research-related reports, the Conference's programme traditionally includes special events such as roundtable discussions, doctoral seminars and presentations of honorary papers. Moreover, in 2017, the April Conference shall serve as a platform for discussion of papers dedicated to strategically important areas of economic and social development based on materials of the Center for Strategic Development.

Furthermore, the Conference's roundtable discussions will cover the following topics: interaction between business and government at the regional and municipal level: the global and Russian experience, prospects for development in Russia's regions: views and opportunities of regional elites, the fate of economic programmes and reform in Russia, and the economic community and rankings of Russian economic journals, as well as other current issues related to the Russian and global economy, technological development, education and social policy. Members of the Russian Government, senior officials of the Presidential Administration of the Russian Federation, and several of the most high profile representatives from the business community and civil society shall take part in the Conference. The Conference's discussions have become an essential part of an important dialogue between the Russian authorities, the expert community, and the general public.

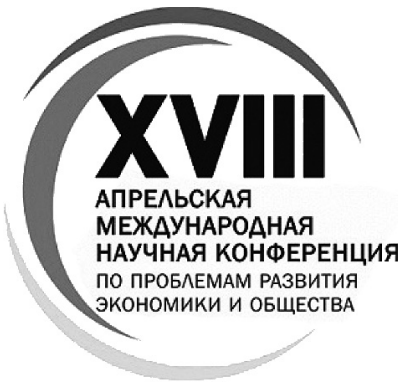

Москва, 11-14 апреля 2017 г.

Начиная с 2000 года Высшая школа экономики ежегодно проводит Апрельскую международную научную консреренцию по проблемам развития экономики и общества. Председателем Программного комитета конференции является профессор Е.Г. Ясин, научный руководитель ВШЭ. Среди проводимых в России междисциплинарных конференций по общественным наукам это мероприятие является крупнейшим по числу участников и представительству международного исследовательского сообщества. В конференции неоднократно участвовали лауреаты Нобелевской премии, принимают участие ведущие эксперты Всемирного Банка и Организации экономического сотрудничества и развития. В 2017 году в консреренции примут участие около 2000 человек, включая 200 иностранных участников. Докладчики Апрельской конференции отбираются по результатам экспертизы научных докладов, которая осуществляется признанными экспертами в соответствующих областях знаний. По итогам академической экспертизы в этом году сформировано 240 сессий, на каждой из которых будет представлено 3-4 доклада по проблемам экономики, социологии, права, политологии, менеджмента, государственного управления, финансам и другим общественным наукам.

Наряду с научными докладами программа конференции традиционно включает специальные мероприятия - круглые столы, аспирантские семинары, почетные доклады. В 2017 году Апрельская консреренция станет площадкой для экспертного обсуждения докладов о стратегических направлениях экономического и социального развития, которые будут подготовлены на основе материалов Центра стратегических разработок. Круглые столы конференции будут посвящены, в частности, следующим темам: «Взаимодействие власти и бизнеса на региональном и муниципальном уровне: зарубежный и российский опыт», «Перспективы развития регионов России: взгляды и возможности региональной элиты», «Судьба экономических программ и реформ в России», «Экономическое сообщество и ранжирование российских экономических журналов» и другим актуальным проблемам российской и мировой экономики, технологического развития, образования и социальной политики. В мероприятиях конференции примут участие члены Правительства Российской Федерации, руководящие сотрудники Администрации Президента Российской Федерации, видные представители гражданского общества и бизнеса. Дискуссии в рамках конференции стали неотьемлемой частью диалога российской власти с экспертным сообществом и широкой общественностью. 
Articles should be topical and original, should outline tasks (issues), describe key results of the author's research and appropriate conclusions.

Manuscripts are submitted via e-mail: bijournal@hse.ru.

\section{MANUSCRIPT REQUIREMENTS}

TEXT FILES should be submitted in electronic form, as a MS Word document (version 2003 or higher).

LENGTH. Articles should be between 20 and 25 thousand characters (incl. spaces).

FONT, SPACING, MARGINS. The text should be in Times New Roman 12 pt, 1.5 spaced, fit to the width, margins: left -25 $\mathrm{mm}$, all other $-15 \mathrm{~mm}$.

TITLE of the article should be submitted in native language and English.

AUTHORS' DETAILS are presented in native language and English. The details include:

$\downarrow$ Full name of each author

$\downarrow$ Position, rank, academic degree of each author

- Affiliation of each author, at the time the research was completed

$\downarrow$ Full postal address of each affiliation (incl. postcode / ZIP)

$\downarrow$ E-mail address of each author.

\section{ABSTRACT are presented in native language and English.}

- The abstract should be between 200 and 300 words.

$\downarrow$ The abstract should be informative (no general words), original, relevant (reflects your paper's key content and research findings); structured (follows the logics of results' presentation in the paper)

- The recommended structure: purpose (mandatory), design / methodology / approach (mandatory), findings (mandatory), research limitations / implications (if applicable), practical implications (if applicable), originality / value (mandatory).

$\uparrow$ It is appropriate to describe the research methods/methodology if they are original or of interest for this particular research. For papers concerned with experimental work the data sources and data procession technique should be described.

- The results should be described as precisely and informatively as possible. Include your key theoretical and experimental results, factual information, revealed interconnections and patterns. Give special priority in the abstract to new results and long-term impact data, important discoveries and verified findings that contradict previous theories as well as data that you think have practical value.

- Conclusions may be associated with recommendations, estimates, suggestions, hypotheses described in the paper.

$\downarrow$ Information contained in the title should not be duplicated in the abstract. Authors should try to avoid unnecessary introductory phrases (e.g. "the author of the paper considers...»).

- Authors should use the language typical of research and technical documents to compile your abstract and avoid complex grammatical constructions.

$\downarrow$ The text of the abstract should include key words of the paper.

KEYWORDS are presented in native language and English. The number of key words / words combinations are from 6 to 10 (separated by semicolons).

FORMULAE should be prepared using Math Type or MS Equation tool.

FIGURES should be of high quality, black and white, legible and numbered consecutively with Arabic numerals. All figures (charts, diagrams, etc.) should be submitted in electronic form (photo images - in TIF, PSD or JPEG formats, minimum resolution $300 \mathrm{dpi})$. Appropriate references in the text are required.

REFERENCES should be presented in Harvard style and carefully checked for completeness, accuracy and consistency.

The publication is free of charge. 
Представляемая для публикации статья должна быть актуальной, обладать новизной, отражать постановку задачи (проблемы), описание основных результатов исследования, выводы, а также соответствовать указанным ниже правилам оформления.

Текст должен быть тщательно вычитан автором, который несет ответственность за научно-теоретический уровень публикуемого материала.

Материалы представляется в электронном виде по адресу:

bijournal@hse.ru.

\section{ТРЕБОВАНИЯ К ОФОРМЛЕНИЮ СТАТЕЙ}

ТЕКСТ СТАТЬИ представляется в редакцию в электронном виде (в формате MS Word, версия 2003 или выше).

ОБЪЕМ. Ориентировочный объем статьи составляет 20-25 тысяч знаков (с пробелами).

\section{ШРИФТ, ФОРМАТИРОВАНИЕ, НУМЕРАЦИЯ СТРАНИЦ}

ШРИФТ - Times New Roman, кегль набора - 12 пунктов, полуторный интервал, форматирование по ширине. Нумерация страниц вверху по центру, поля: левое - 2,5 см, верхнее, нижнее и правое по $1,5 \mathrm{~cm}$.

НАЗВАНИЕ СТАТЬИ ПрИводится на рУсСКом и английском язЫках. Название статьи должно быть информативным и раскрывать содержание статьи.

СВЕДЕНИЯ ОБ АВТОРАХ прИВОДятСя На русСКом И англиЙСКОМ языках и включают следующие элементы:

$\downarrow$ фамилия, имя, отчество всех авторов полностью

$\downarrow$ должность, звание, ученая степень каждого автора

$\checkmark$ полное название организации - места работы каждого автора в именительном падеже, полный почтовый адрес каждой организации (включая почтовый индекс)

\ адрес электронной почты каждого автора.

АННОТАЦИЯ К СТАТЬЕ представляется на русском и английском языках.

$\uparrow$ Объем - 200-300 слов.

^ Аннотация должна быть информативной (не содержать общих слов).

$\downarrow$ Аннотация должна отражать основное содержание статьи и быть структурированной (следовать логике описания результатов в статье).

$\downarrow$ Структура аннотации: предмет, цель, метод или методологию проведения исследования, результаты исследований, область их применения, выводы.

\ Метод или методологию проведения исследований целесообразно описывать в том случае, если они отличаются новизной или представляют интерес с точки зрения данной работы. В аннотациях статей, описывающих экспериментальные работы, указывают источники данных и характер их обработки.

$\downarrow$ Результаты работы описывают предельно точно и информативно. Приводятся основные теоретические и экспериментальные результаты, фактические данные, обнаруженные взаимосвязи и закономерности. При этом отдается предпочтение новым результатам и дан- ным долгосрочного значения, важным открытиям, выводам, которые опровергают существующие теории, а также информации, которая, по мнению автора, имеет практическое значение.

- Выводы могут сопровождаться рекомендациями, оценками, предложениями, гипотезами, описанными в статье.

$\checkmark$ Сведения, содержащиеся в названии статьи, не должны повторяться в тексте аннотации. Следует избегать лишних вводных фраз (например, «автор статьи рассматривает...»).

\ Исторические справки, если они не составляют основное содержание документа, описание ранее опубликованных работ и общеизвестные положения, в аннотации не приводятся.

$\downarrow$ В тексте аннотации следует употреблять синтаксические конструкции, свойственные языку научных и технических документов, избегать сложных грамматических конструкций.

$\downarrow$ В тексте аннотации следует применять значимые слова из текста статьи

КЛЮЧЕВЫЕ СЛОВА привОДяТся на рУсском И ангЛийском яЗЫкаХ. Количество ключевых слов (словосочетаний) - 6-10. Ключевые слова или словосочетания отделяются друг от друга точкой с запятой.

ФОРМУЛЫ. При наборе формул, как выключных, так и строчных, должен быть использован редактор формул MS Equation. B формульных и символических записях греческие (русские) символы, а также математические функции записываются прямыми шрифтами, а переменные аргументы функций в виде английских (латинских) букв наклонным курсивом (пример «cos a», «sin b», «min», «max»). Нумерация формул - сквозная (по желанию авторов допускается двойная нумерация формул с указанием структурного номера раздела статьи и, через точку, номера формулы в разделе).

РИсунки (графики, диаграммы и т.п.) могут быть оформлены средствами MS Word или MS Excel. Ссылки на рисунки в тексте обязательны и должны предшествовать позиции размещения рисунка. Допускается использование графического векторного файла в формате wmf/emf или cdr v.10. Фотографические материалы предоставляются в формате TIF или JPEG, с разрешением изображения не менее 300 точек на дюйм. Нумерация рисунков - сквозная.

ТАБЛИЦЫ оформляются средствами MS Word или MS Excel. Нумерация таблиц - сквозная.

СПИСОК ЛИТЕРАТУРЫ Составляется В СоОтветствиИ С требованиями ГОСТ 7.0.5-2008. Библиографическая ссылка (примеры оформления размещены на сайте журнала http://bi.hse.ru/). Нумерация библиографических источников - в порядке цитирования. Ссылки на иностранную литературу - на языке оригинала без сокращений.

СПИСОК ЛИТЕРАТУРЫ ДЛЯ АНГЛОЯЗЫЧНОГО БЛОКА оформляется в соответствии с требованиями SCOPUS (примеры оформления размещены на сайте журнала http://bi.hse.ru/). Для транслитерации русскоязычных наименований можно воспользоваться сервисом http://translit.ru/.

\section{ЛИЦЕНЗИОННЫЙ ДОГОВОР}

Для размещения полнотекстовых версий статей на сайте журнала с авторами заключается лицензионный договор о передаче авторских прав.

Плата с авторов за публикацию рукописей не взимается. 